\title{
Police Institutions and Police Abuse: Evidence from the US
}

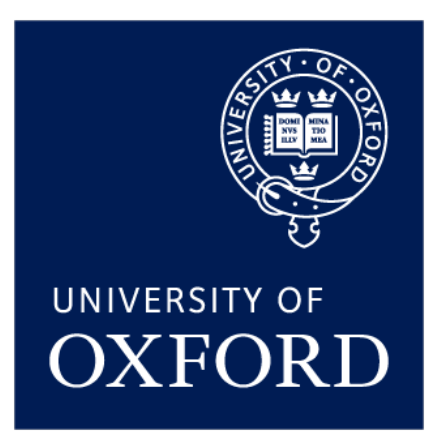

A thesis submitted in partial fulfilment of the requirements for the degree of

\author{
Master of Philosophy in Politics: Comparative Government \\ Department of Politics and International Relations \\ University of Oxford
}

Author: Abdul N. Rad

Academic Advisor: Dr. Alexander G. Kuo 


\section{Abstract}

What can explain variation in police abuse across America's largest enforcement agencies? This question is salient given the media attention and the investigations conducted by the US Department of Justice finding problems of accountability and transparency in America's policing apparatus. Situating itself on the intersection between public-sector union, special interest group, American politics, and criminology literature, this thesis argues that police union mechanisms, specifically police protections, can explain variation in police abuse. The study employs an originally constructed index of police protections comprised of police union contract and Law Enforcement Officer Bill of Rights (LEOBR) provisions. First, I find a positive and significant relationship between police abuse and police protections. Second, while local-level ideology has no influence on the ability of unions to create police protections, state-level ideology vis-à-vis state labour laws hinder the ability of unions to create police protections. Finally, to address alternative explanations for continued abuse, I present a paired, qualitative case study of Chicago, IL, and Dallas, TX. I demonstrate the importance of labour histories and minority law enforcement unions for creating better policing outcomes. 


\section{Acknowledgements}

"Power is easily misused by those in power. You either roll over or you fight back."

This thesis is dedicated both to the life of Myron Beldock, Esq. (1927-2016) who devoted his life fighting wrongs in the American criminal justice system and to his clients who were the real heroes in the fight for a free and fair justice system.

I am indebted to dozens of individuals in my life who have not only made this thesis possible but provided me with the opportunity to study at Oxford. First, I would like to thank my family endlessly for their love and support and sacrifice, specifically my sister, Fatoma. Second, I thank the officers and interviewees for their participation and their commitment to careers in public service protecting American communities. Third, a special thank you to Erik Mebust, Gabriel Delaney, Alex Coccia, and Samuel Levy for their feedback and review. Similarly, I would like to express thanks to Neal Barsch, Aven Satre-Meloy, Navin Cooray, and Anis Gammage for glancing over the quantitative methods employed in this paper. Next, I thank Dr. Alex Kuo, my academic supervisor, for his continued support and expertise throughout the whole process. Additional thanks: Dr. Stephen Rushin and Arthur Rizer for their expert feedback; The Dugas family (Tina, Jeffrey, and Taylor) for their hospitality and assistance in Chicago; and to the dedicated researchers at Campaign Zero (especially Samuel Sinyangwe) who have gathered and constructed some of the data employed in this paper.

I would like to express my gratitude to the Beldock, Levine \& Hoffman family who have provided me with guidance, motivation, and financial support to make my studies a reality. Thank you for providing me with the opportunity to work on a range of cases during my employment which revealed the fault lines in America's criminal justice system. I thank Karen Dippold for inspiring the research topic, Luna Droubi for continued motivation, and Keith Szczepanski for his continued faith and support. The generosity, love, and support from Katherine Thompson and Jonathan Pollack were both critical in providing me with the luxury to attend Oxford. 


\section{Table of Contents}

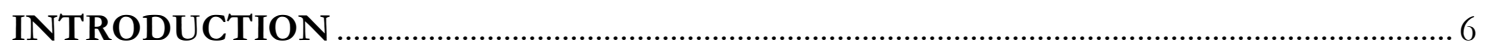

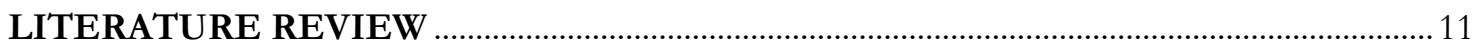

Origins of Police Culture \& Race .................................................................................................. 12

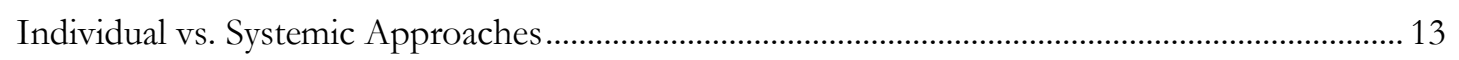

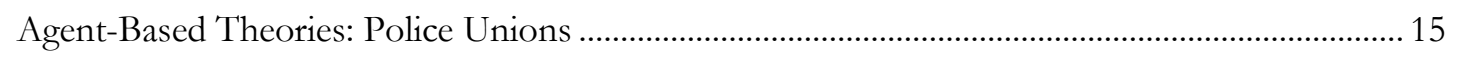

Identifying the Gaps ............................................................................................................ 20

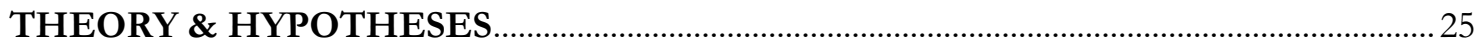

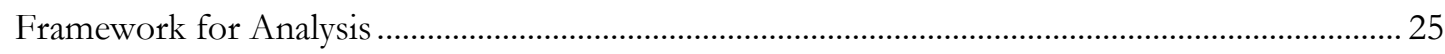

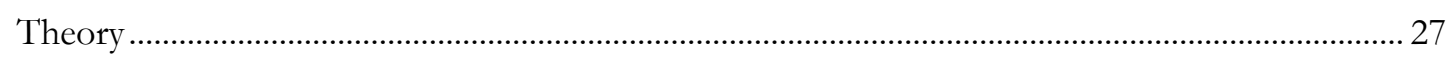

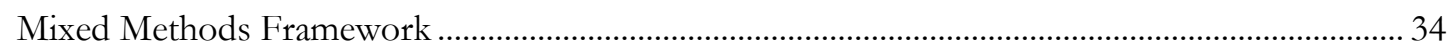

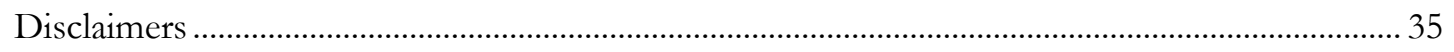

DATA \& CONSTRUCTION OF INDEX OF POLICE PROTECTIONS.............................. 37

Context on Data in American Criminology ………………………………................................... 37

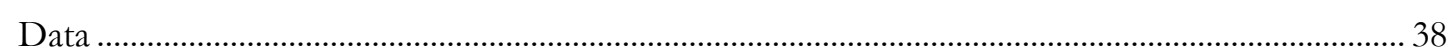

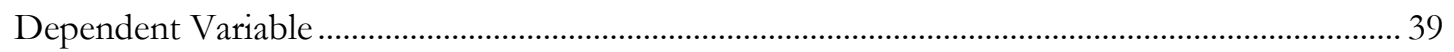

Independent Variable: Index of Police Protections............................................................................. 41

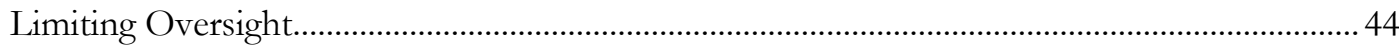

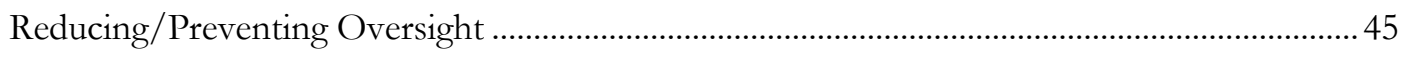

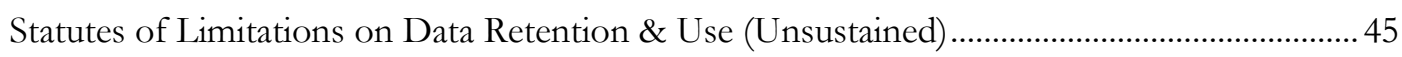

Statutes of Limitations on Data Retention \& Use (Sustained) ......................................................... 46

Requiring City to Pay for Legal Costs and Indemnification........................................................ 47

Requiring City to Pay for Suspension/Fees .............................................................................. 47

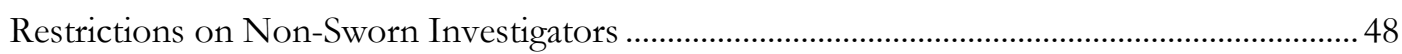

Unfair Access to Investigative Materials (Full Access)................................................................ 48

Limitations on Filing of Complaint ....................................................................................... 49

Formal Waiting Periods that Delay Investigations.......................................................................5 50

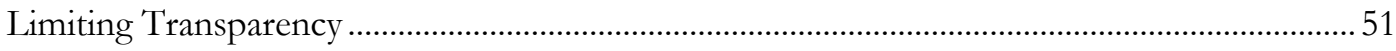

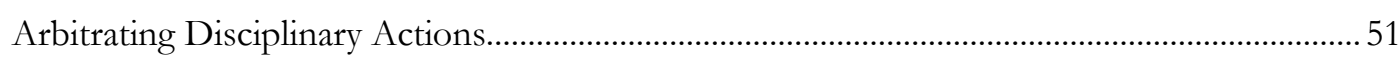

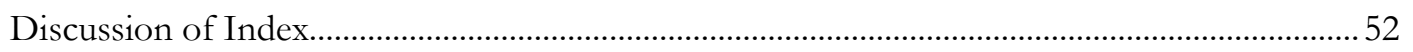

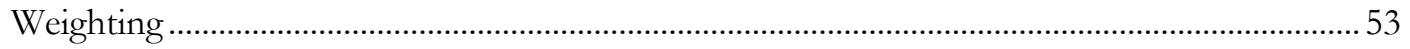

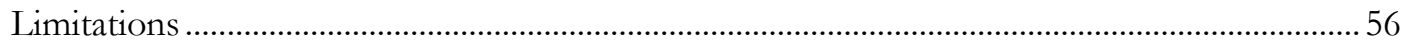

Independent and Control Variables............................................................................................. 57

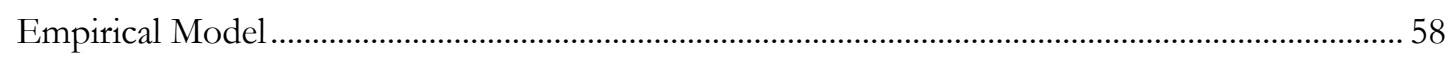

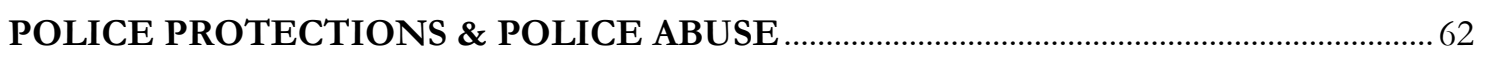

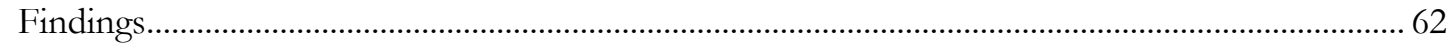

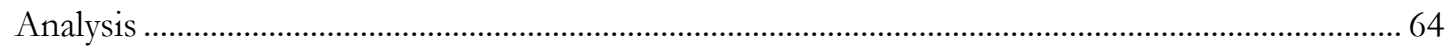




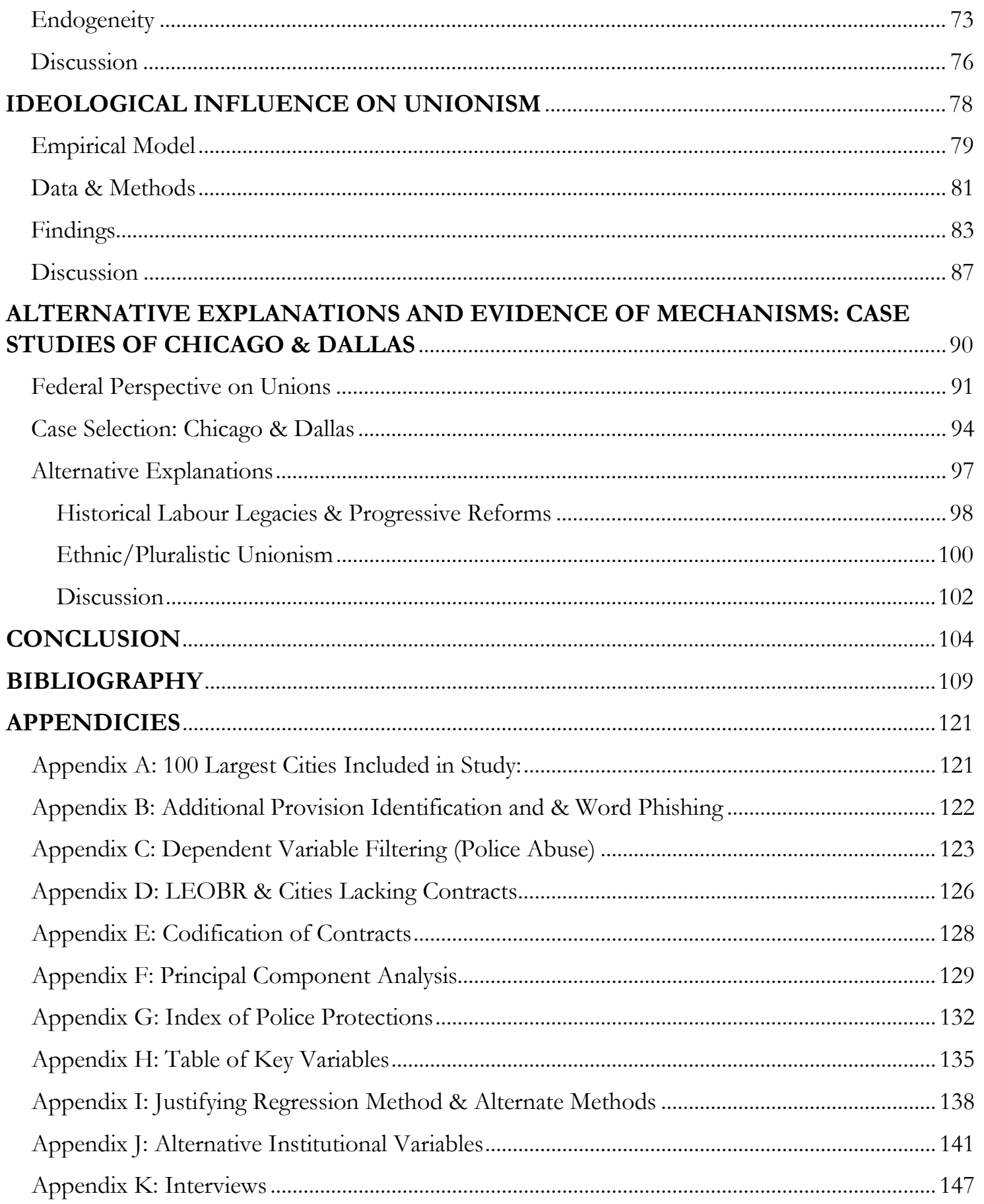




\section{CHAPTER 1}

\section{INTRODUCTION}

In the period between 2000-2005, officer Kevin Osborn of the Chicago police department received 38 civilian complaints. ${ }^{1}$ They involved several allegations of excessive use of force, false arrests, and illegal searches. In 2001, a civil federal jury found two officers, one of them being Osborn, guilty on charges of false arrest, excessive use of force and illegal entry. ${ }^{2}$ There has been no record of any disciplinary action against officer Osborn. ${ }^{3}$

The 2008 election of Barack Obama placed criminal justice reform as a priority on the national agenda. Most prominent in terms of visibility was the work on reforming police departments by the US Department of Justice (DOJ). DOJ investigations frequently found police departments struggling to hold their officers accountable, often citing crippled accountability systems. ${ }^{4}$ The "President's Task Force on $21^{\text {st }}$ Century Policing" advocated for an agenda focused on reforming police departments across the US. ${ }^{5}$ In the case of Chicago, there have been 56,459 allegations against police officers between 2000 and 2005, resulting in only 2,320 sustained complaints. ${ }^{6}$ The complaints filed range from illegal

\footnotetext{
1 The Invisible Institute, “Citizens Data Police Project” Database, 2016.

2 O’Connor, 2001.

${ }^{3}$ The Invisible Institute, "Citizens Data Police Project" Database, 2016.

${ }^{4}$ Kelly, Childress, and Rich, 2015.

${ }^{5}$ Huq, 2017.

${ }^{6}$ The Invisible Institute, "Citizens Data Police Project" Database, 2016.
} 
searches that violate an individuals' rights, to excessive use of force incidents that have resulted in civilian deaths. Officer Osborn is but one example.

The Chicago Police Department may represent one of the more troubled departments in the US, but it is not alone. The death of Eric Garner involved a fatal chokehold administered by a white New York Police Department (NYPD) officer on an unarmed black male. The officer was placed on desk duty but received a $\$ 20,000$ pay raise in the same year following the incident and faced no internal disciplinary charges. ${ }^{7}$ Studies have highlighted how departments frequently use "routine brutality" and how it impacts racial minority groups. ${ }^{8}$

Studies highlighting patterns of abuse and problems of accountability raise the question of why police departments in the US vary greatly in their capacity to comply with general norms or laws surrounding abuse against civilians. Moreover, the question at the heart of the problem is how abuse continues to endure and what mechanisms can be accredited with playing a role. This question is salient given the increasing media coverage of police shootings of unarmed civilians, and excessive use of force incidents (predominantly against African-Americans and/or other minorities). Not only is the question one of policy importance, but it relates to a broader issue in comparative politics: why do the basic locallevel organs of the "state" — the enforcement agencies that citizens in principle rely on for protection - vary in how much violence or mistreatment they conduct against civilians they are ostensibly obligated to protect? The disparate use of violence against specific groups, and lack of compliance by the institution in which the state allocates the monopoly of power, naturally lends itself to problems of distrust and state illegitimacy. ${ }^{9}$ Moreover, as

\footnotetext{
7 Parry, 2017.

${ }^{8}$ Huq, 2017, P. 42.

${ }^{9}$ Huq, 2017.
} 
highlighted by Huq, the type of policing "employed in a nation will necessarily influence the health of its democracy." ${ }^{10}$ Thus, it is pertinent to ask: why do US police departments vary in these outcomes?

It is then plausible to investigate what local structures or groups may have an interest in preserving status quo police practices and behaviours. Over $80 \%$ of police officers across the country are represented by collective bargaining organizations. ${ }^{11}$ Police unions, which can also be viewed as special interest groups with vested interests to safeguard their members, have been cited fighting against the implementation of reforms and taking actions which are contradictory to fundamental democratic principles of accountability and transparency. ${ }^{12}$ While there has been some discussion in policing literature highlighting how police unions undermine accountability, only recently has there been more quantitative exploration on the application of existing theories. A recent significant finding claims a connection between collective bargaining and police misconduct. ${ }^{13}$ Yet, there is currently no established link with a specific union mechanism which may continue abuse and safeguard officers. ${ }^{14}$

In this thesis, I argue that citizen abuse (by police) is directly and positively correlated to the robustness of protections afforded to police through union mechanisms. First, I evaluate the argument that variation in police protections, created via union contracts and Law Enforcement Officer Bill of Rights (LEOBRs), can partially account for variation in police abuse. While the role of public sector unions has been discussed in other occupations and policy realms (prominently education), the specific role of police unions in the case of abuse and accountability has received very little attention in political science

\footnotetext{
${ }^{10}$ Huq, 2017, P. 42.

11 Bies, 2017; US DOJ, LEMAS Dataset, 2013.

12 Ibid.

13 Dharmapala, McAdams, and Rappaport, 2017.

14 Ibid.
} 
and criminology. Subsequently, I draw on existing literature in contemporary public-sector unionism to shed light on how political ideology influences the ability of a union to create union mechanisms to insulate abuse, specifically police protections. The failure and neglect of criminologists to properly look at how politics may influence unions' abilities have hindered the understanding of how unions maintain the status quo.

I present three empirical tests of my hypotheses using a mixed methods approach utilizing several datasets, the codification of key union contract provisions, lawsuits, press statements, news clippings, and interviews. I test the argument that greater levels of union contract police protections (independent variable), measured by an originally constructed index, are likely to be found in cities with greater levels of police abuse (dependent variable). I expect police institutions to be significant, but of course in conjunction with other more standard variables (such as race) that one might expect to correlate with police behaviour and abuse. The second empirical test analyses whether the political ideology can explain the variation in the level of police protections in place. This will be tested by alternating the originally constructed index of police protections to the dependent variable and determining its relationship with city level ideologies (ideological scores) and statelevel ideologies (vis-à-vis state labour laws). Drawing theories from public sector unionism, I expect conservatism at the state level to restrain the ability of unions to create strong police protections. ${ }^{15}$ The last empirical test will supplement the two quantitative tests with a case study of Chicago, Illinois, and Dallas, Texas, which stand as contrasts in terms of police behavior and police protections. This paired study will explore alternative explanations for how unions, particularly union structures and its labour environments, can explain the different outcomes between the two cities.

${ }^{15}$ Freeman and Han, 2012; Hacker and Pierson, 2010. 
The thesis proceeds as follows. Following this introductory chapter, the second chapter presents the literature review in criminology and engagement in relevant public-sector union literature. The third chapter presents a brief overview of the hypotheses and theory, based on initial probing of evidence and relevant case studies, as well as application of existing theories. The fourth chapter presents the data and the construction of the original index of police protections. The fifth chapter discusses the findings, exploring the key hypotheses surrounding police protections and police abuse. The sixth chapter investigates how political ideology may influence the level of protections in place and examines where officers are likely to receive more protections. The seventh chapter employs a qualitative approach to explore alternative explanations that may explain how unions can maintain the status quo beyond the scope of police protections.

This study aims to establish whether there is a relationship between abuse and police protections which are created by unions. A common problem in many studies is that of endogeneity--in this case, whether abuse itself creates protections rather than vice versa. This study will combat this issue with different tests and examples. Moreover, today's controversial policing practices are not the product of recent events; rather, it is plausible that these practices were born out of the Nixon-era "War on Drugs" and subsequently insulated over time with police union mechanisms.

The thesis ends with implications of this argument on unionism more broadly in the US. This is a nuanced argument, and in no way argues that unions, as a whole, are problematic. Rather, this study highlights how specific union mechanisms are safeguarding abusive practices among law-enforcement in the hopes that these practices can be corrected through recommended reforms. 


\section{CHAPTER 2}

\section{LITERATURE REVIEW}

In order to appropriately conceptualize the question this study is investigating, I first discuss the existing literature on related questions of criminology and public-sector unions in the US. These topics have been addressed, for the most part, in isolation from one another. Synthesizing this literature is a critical and novel first step in understanding the relationship between the politics of criminal justice reform, police abuse, deterrence, accountability, and public-sector unionism.

First, I will be discussing the origins and problems with the existing status quo of police practices and behavior which has been inaugurated to have been shaped by the Nixon-era "War on Drugs." ${ }^{16}$ Next, I focus on two different schisms which explain continued misconduct: individual versus systemic. An intersection upon both theories can best be encompassed by police union literature which demonstrates how union mechanisms shape the systemic and individual problems. Moreover, police unions have been illustrated to have a clear interest in preserving the status quo, opposing reforms and weakening accountability systems. While the field has recently received greater attention, it is largely underexplored unlike some of its public-sector counterparts, most notably education. Finally, I attempt to bridge the theories in different fields to better frame the gaps in the literature.

${ }^{16}$ Mauer, 2017; Miller, 2008; Baumgartner, et al, 2006. 


\section{Origins of Police Culture \& Race}

Scholarship on policing has highlighted the large array of issues crippling America's policing apparatus, ranging from misconduct to militarization. Problems within America's criminal justice system cannot be understood without discussing its history and touching upon its racial dynamics. This will better inform this study's evaluation of the origins of police culture, the racial implications of the "War on Drugs," and some of the problems with safeguarding specific aspects of existing practices and behaviors embedded in policing culture.

Policing reform, in recent years, has visibly become a more politicized topic of discussion among politicians than in past decades. ${ }^{17}$ Politicians have been entrenched in two camps: addressing the need to reform or stressing the importance of "law and order." Stevenson highlights that America's criminal justice system was employed as a tool to "maintain white supremacy and racial subordination." 18 Moreover, the agents of the policing system were used to harass and subjugate black people which he argues shaped "the criminal justice system ....for the next century." ${ }^{19}$ Mauer poses an important question that best characterizes the policies which shaped America's criminal justice system and characterizes the existing state of affairs: "How a society chooses to advance public safety is very much a function of how it conceptualizes the problem and the means of producing the outcomes it desires.” ${ }^{20}$ In 2010, 40\% of America's incarcerated persons were Black males despite Blacks only comprising $13 \%$ of the general US population. ${ }^{21}$ Mauer argues that policies instituted to fight the "War on Drugs", declared by President Nixon in 1971,

\footnotetext{
17 It is important to highlight that policing reform is but one component of criminal justice reform: there is already a great deal of literature on correctional, judiciary, and prosecutorial reform, which are beyond the scope of this thesis. 18 Stevenson, 2017, P. 15.

19 Ibid.

20 Mauer, 2017, P. 33.

21 Sakala, 2014.
} 
included race-neutral codes which made no explicit mention of Blacks, yet implicitly targeted and criminalized Blacks. ${ }^{22}$ Davis highlights that Blacks are disproportionately more likely to be arrested, killed or injured during a police encounter, imprisoned, and receive longer prison sentences. ${ }^{23}$ Thus, America's history with race, specifically in the last half-century which represents a shift of "historic proportions, is inherently linked with police abuse and the existing status quo in the criminal justice system. ${ }^{24}$

\section{Individual vs. Systemic Approaches}

Existing literature in the field of policing, albeit broad and diversified, identifies several explanations for variation in misconduct and police violence. Literature focused on Canadian police misconduct characterizes two divergent schools of thought on the source of misconduct and abuse: individual and systemic (also referred to as individualistic v. structural). ${ }^{25}$

The individualist approach (also referred to as officer-centric), is premised upon the 'rotten-apple' theory which argues that abuse or misconduct is the result of a few rogue officers, instead of systemic problems. ${ }^{26}$ However, many of the theories in this approach have often returned or led to how specific demographics are more likely to be targeted, which suggests structural or organizational explanations. ${ }^{27}$ Furthermore, Tator and Henry discredit officer-centric approaches by arguing that they are premised upon the idea that problems of racial profiling and abuse can be simply resolved by having a more racially

22 Stevenson, 2017; Mauer, 2017.

${ }^{23}$ Davis, 2017.

${ }^{24}$ Mauer, 2017, P. 31.

${ }^{25}$ Bonanno, 2015. It is worth noting that this literature on 'officer v. structural' approach is more developed and concentrated on Canadian policing.

${ }^{26}$ Sherman, 1978.

${ }_{27}$ Terril, 2005. 
diverse police force. ${ }^{28}$ Some evidence does support the theory that increased positive interracial interactions reduce individual bias While officer-centric approaches are valid such as evidence that increased positive interracial interactions reduce individual bias, they neglect to address how societal and organizational factors can create misconduct and do not solve clear structural problems. ${ }^{29}$ Thus, it is important to shift attention to the intersection of social factors and organizational features which may collectively safeguard "bad officers" while sustaining controversial policing practices. ${ }^{30}$

Among proponents for the sociological and structural framework, there are competing and overlapping hypotheses: spatial, community accountability, and minority threat theories. In terms of predictors for the use of violence, the Minority Threat ("MT") and Spatial hypotheses have been successful determining in which communities police are likely to use violence or excessive force. ${ }^{31}$ The MT hypothesis stipulates that cities with larger populations of Black and Hispanics are likely to exhibit a greater number of instances involving police violence and excessive force. Second, the place hypothesis focuses on how the level of segregation and densities of Black and Hispanic groups are likely to be correlated with more violence and abuse. ${ }^{32}$ Other studies have found that Blacks and Hispanics are more likely to be the subject of police use of force and misconduct. ${ }^{33}$

Studies employing civilian complaint data further support sociological theories with three primary findings that are worth noting. First, a small percentage of officers are found to compose a disproportionate amount of misconduct. ${ }^{34}$ Second, the vast majority of

\footnotetext{
28 Tator and Henry, 2006.

29 Smith and Holmes, 2014.

30 Bonanno, 2015.

31 Smith and Holmes, 2014; Holmes, 2000; Smith, 1986.

32 Smith and Holmes, 2014.

33 Fryer, 2016.

34 Walker, 2001.
} 
complaints are excessive use of force allegations, incidents where the officer uses unlawful force or violence against a civilian. ${ }^{35}$ Third, most complaints are filed by non-White male persons and those filed by Black persons are less likely to be sustained, thus, failing to result in any disciplinary action against the officer. ${ }^{36}$ Smith and Holmes employed complaint data confirmed the MT and Spatial hypotheses looking at data across America's largest cities. ${ }^{37}$ They also found a significant positive correlation among cities that employ more Hispanic officers in the southwest region of the US. This is the theory behind the community accountability hypothesis which is that police departments that are more racially reflective of the community are likely to use less force or violence. Sociological and structural approaches are sufficient in explaining where there is likely to be more police abuse, they do not explain what may safeguard officers and continue abuses. ${ }^{38}$

\section{Agent-Based Theories: Police Unions}

Criminology accredits resistance to reform to several different actors including mid-level and top managers. However, the field, in recent years, has had more attention on police unionism and how it may hinder accountability through different actions and processes. ${ }^{39}$ Moreover, it renders unions to be relevant on a number of fronts, most notably in weakening accountability. This has been observed and discussed on a multitude of fronts ranging from lobbying, opposing and weakening of civilian oversight boards, and creating procedural protections and legal battles. ${ }^{40}$ The majority of studies discussing police accountability operate under the premise that officers are rational actors and thus respond to deterrence practices. However, recent literature has also empirically argued that deterrence or rational-choice theories are ineffective for explaining citizen behaviour and

\footnotetext{
35 Hickman, Piquero, and Greene, 2000.

36 Terril and Ingram, 2015.

${ }^{37}$ Smith and Holmes, 2014.

38 Gupta, 2017; Blumer, 1958.

${ }^{39}$ Magnenau and Hunt 1993, 1996; Walker, 1983.

40 Juris and Feuille, 1973.
} 
compliance with the law. Instead, it finds that "procedural justice" is best suited as an explanation. ${ }^{41}$ This theory posits that the perceived legitimacy of the state and its enforcement apparatus can explain citizen compliance with the law. ${ }^{42}$ While this recent literature disputes deterrence theories; it also argues that the lack of compliance or continued abuse by the enforcement agency is the problem for the lack of compliance by its citizenry. ${ }^{43}$ Thus, failing to discuss why abuses or unfairness endures within the enforcement agency or what sustains these practices. ${ }^{44}$ Therefore, prior to discussing how unions take actions that weaken accountability systems, it is important to describe how deterrence theory functions and how it relates to continued misconduct.

Stone and Ward argue that there are three dimensions which need to be considered when creating accountability systems to deter misconduct: internal or departmental control, state or governmental control, and social control. ${ }^{45}$ Thus, union mechanisms, such as contract provisions that limit or infringe on these spheres can create an atmosphere that is more accepting of misconduct since there is no fear of consequence. ${ }^{46}$ Moreover, Pogarsky and Piquero's study finds that a combination of standard deterrence practices and extra-legal sanctions are effective in reducing police misconduct. ${ }^{47}$

Prior to discussing unions' impact on accountability and interests in reducing deterrence or reducing "procedural justice", it is important to provide context on unionism literature. There has been considerable literature on unionism and the relationship with improved

\footnotetext{
${ }^{41}$ Huq, 2017; Tyler, 2003.

42 Huq, 2017.

43 Tyler, 2003.

44 Huq, 2017.

45 Stone and Ward, 2000.

46 Ibid.

47 Pogarsky and Piquero, 2004.
} 
benefits and wages in a range of different sectors. ${ }^{48}$ A recent study employing panel data found there to be a relationship between rising departmental expenditures and unions (police and fire) that have collective bargaining powers. ${ }^{49}$ Other literature focuses on how non-unionized workers receive better wages in areas where there is a stronger union presence. ${ }^{50}$ Freeman and Han suggest that public sector unionism, like private sector unionism, draws its lobbying and political pressure from the size of the union. ${ }^{51}$ Furthermore, it investigates how non-unionized agencies are affected by strong neighboring unions as well as the differences in levels of employment. ${ }^{52}$ Finally, another important note is that unions in "right-to-work" states (states which do not allow unions to require their membership to financially contribute to representation) are less effective than counterparts in other neighboring states. ${ }^{53}$

Most pertinent to this study is the literature focused on accountability and reform. While there has been a great deal of literature surrounding problems of accountability in other public-sector unions, most notably education, police union scholars have highlighted the lack of scholarship and have emphasized the need for more scholarship on its relationship with undermining accountability. ${ }^{54}$ Studies focusing on unionism and accountability, primarily operating through a qualitative lens, have argued that police unions work to block progressive reforms aimed at repairing accountability systems. ${ }^{55}$ Scholars have discussed how unions employ different instruments such as lobbying and contracts to frustrate accountability and reduce transparency. ${ }^{56}$ One study finds that unions have a

48 Delaney and Feuille, 1985; Doerner and Demuth, 2009; Feuille and Delaney, 1986; Feuille, Hendricks, and Delaney, 1983; Freeman and Valletta, 1988; Trejo, 1991; Wilson et al., 2006; Zhao and Lovrich, 1997.

49 Moe and Anzia, 2013.

${ }^{50}$ Freeman, Han, Badland, and Duke, 2015.

51 Ibid.

52 Moe and Anzia, 2014.

53 Putchinski, 2007.

54 Walker, 2008.

55 Walker, 2008; Bies, 2017; Epp, 2009; Fisk and Richardson, 2016; McCormick, 2015; Magenau and Hunt, 1996.

56 Bies, 2017; Walker, 2008. 
large part to play in safeguarding officer misconduct by blocking legislation intended to increase transparency and accountability. ${ }^{57}$ The effectiveness of unions blocking reforms and maintaining the status quo can be better understood in relationship to both American Political Development (APD) and special interest group literatures which argue how the design of the American state benefits special interest groups, specifically, how the system favours police and prosecutors. ${ }^{58}$

Qualitative studies have been successful in exploring the impact of unionism in terms of accountability and transparency. Yet, one limitation is that they often focus on single case studies or small $\mathrm{N}$ comparisons which makes it difficult to conceptualize the parsimonious relationship of unionism across a large range of departments encompassing a range of regions. The use of quantitative methods to explore the effects of police unionism on accountability are scarce, but recent studies have found a positive relationship between misconduct and unionism. ${ }^{59}$ Past studies make arguments which have been discredited by hypotheses posed in recent studies. For example, one study focusing on the impact of collective bargaining on accountability investigates the "losing debate" hypothesis which stipulates police organizations are losing the fight of resistance to reforms. ${ }^{60}$ Their study finds no relationship between the two variables of interest because of methodological flaws and the employment of weak dichotomies for both the independent and dependent variables. ${ }^{61}$ For example, this includes proxying accountability, the dependent variable, with the existence of a civilian review board (binary) which is problematic because authors fail to consider how some union contract provisions found in major cities constrain oversight entities to such an extent that they are virtually powerless. ${ }^{62}$ Another study finds

\footnotetext{
${ }^{57}$ Bies, 2017.

58 Baumgartner and Jones, 1993.; Baumgartner, Jones, and True, 2006; Pierson, 2000.

${ }^{59}$ Dharmapala, et al, 2017.

${ }^{60}$ Wilson and Buckler, 2010.

${ }^{61}$ Walker, 2008.

62 Walker, 2008. Dharmapala, et al, 2017.
} 
a positive relationship with unionism and departments which adopt community oriented policing, but neglect to provide evidence of whether the programs have been effective for increasing accountability and generalizes the types of community oriented policing programs. $^{63}$

A recent study employing a more rigorous quantitative approach analyzed the impact of collective bargaining rights on officer misconduct across the state of Florida. They applied a difference-in-difference quantitative approach and found that departments with bargaining rights resulted in a $27 \%$ increase in officer misconduct, measured by complaints of officer misconduct. ${ }^{64}$ The authors note that there could be different mechanisms which explain the outcome but highlight that it is likely the impact of contract provisions which make "investigations more difficult and less likely to result in significant sanctions." ${ }^{65}$ Moreover, they argue that the combination of time delays and other procedural safeguards "raise the cost of terminating" officers who commit misconduct and in turn reduce deterrence. Similarly, Rushin argues that the collective bargaining process may have a part to play in the insertion of "problematic procedures." ${ }^{66}$ Rushin's study rigorously identified, analyzed, and then codified provisions which are impediments to accountability for 178 union contracts. ${ }^{67} \mathrm{He}$ finds that the large majority of contracts which were analyzed included provisions which "limit interrogations after alleged misconduct, mandate the destruction of disciplinary records, ban civilian oversight, prevent anonymous civilian complaints, indemnify officers in the event of civil suits, and limit the length of internal

\footnotetext{
${ }^{63}$ Morabito, 2014.

${ }^{64}$ Dharmapala, et al, 2017.

${ }^{65}$ Dharmapala, et al, 2017, P. 26.

${ }^{66}$ Rushin, 2017, P. 1192.

${ }^{67}$ Ibid.
} 
investigations." ${ }^{68}$ Other studies look more narrowly at specific categories of provisions which create problems such as the impact of "delay privileges" or formal waiting periods. ${ }^{69}$

Police unionism has received more attention in recent years, most likely the consequence of frequent media attention to police departments. While other factors may play a part in reducing deterrence, scholarship has demonstrated that unions have a clear vested interest in impeding accountability systems and have documented unions effectively blocking reforms which are intentioned to strengthen the democratic principles of accountability and transparency. ${ }^{70}$

\section{Identifying the Gaps}

As highlighted earlier, scholars and journalists have long stressed that there is not enough literature on the role of police unions. ${ }^{71}$ While acknowledging the merits of recent work, specifically the identification of contract provisions by Rushin and the impact of collective bargaining on misconduct as established by Dharmapala, McAdams, and Rappaport, there are still gaps in the literature that constrain our understanding of police unions. ${ }^{72}$ Specifically, relating to understanding which union mechanism create problems and how union powers can be constrained because of other variables.

The first gap in the literature is the lack of adequate testing across a range of observations. Dharmapala, McAdams, and Rappaport's study is a noteworthy contribution which employs rigorous and robust quantitative testing. Their study only looks at the state of Florida which creates a number of problems because there is a LEOBR, which guarantees

\footnotetext{
68 Rushin, 2017.

${ }^{69}$ Huq and McAdams, 2016.

70 Keenan and Walker, 2005.

71 Walker, 2008.

72 Dharmapala, et al, 2017; Rushin, 2017.
} 
that all officers, despite whether the union has a collective bargaining contract will at the very minimum receive some protections. Thus, variation in the study is inherently limited. Additionally, they admit that their endeavour does not pinpoint what mechanism associated with collective bargaining or unionism is specifically responsible for misconduct. They highlight that while procedural safeguards and other provisions reducing deterrence are a potential explanation, they also note that it could be a number of mechanisms such as strengthening pro-worker norms, including the 'code of silence,' which could reduce the recognition of misconduct. ${ }^{73}$

Meanwhile, Rushin's study is impressive for its rigorous analysis and codification of 178 union contracts which has significantly advanced the field. ${ }^{74}$ His qualitative study discusses anecdotal examples of how each provision can create a problem for accountability. ${ }^{75} \mathrm{He}$ finds that a "substantial" number of the contracts contain provisions which frustrate accountability. ${ }^{76}$ While acknowledging the merit of the analysis and construction of the original dataset, there is no quantitative employment of the codified contracts as conducted in studies on teacher unionism. ${ }^{77}$

Therefore, it is important to start bridging the two literatures: police unionism and teacher unionism. Teacher unionism has more data and more refined theories. Most relevant in this case would be the scholarship on teacher unions and accountability. Much of the recent literature finds that teacher unionism has a negative relationship with the performance of schools. Moe constructed an index of restrictiveness by codifying union contracts and found that restrictive contract provisions have a positive correlation with

\footnotetext{
${ }^{73}$ Dharmapala, et al, 2017.

74 Rushin, 2017.

75 Ibid.

76 Ibid.

77 Moe, 2009
} 
lower performing schools. Moreover, scholarship has found a negative correlation between strong teacher unions and performance of already disadvantaged schools, which tend to disproportionately impact minority (Black \& Hispanic) communities. These studies primarily use local-level district data and are run against accountability variables which tend to be measured by school performance scores and test scores. Thus, while continuing to acknowledge the merit of existing works on police institutions, it is necessary to draw parallels to literature studying other public-sector unions.

Unions were created, in large part, as a response by workers to protect their rights from abusive employers. However, private-sector union membership started to diminish for a number of explanations; ranging from the shift away from a World War II manufacturing economy to the passage of anti-union legislations or the creation of weak state labour laws. ${ }^{78}$ Simultaneously, there was an emerging membership in public-sector unions around the 1950s that started to garner momentum with the assistance of organizations such as the County and Municipal Employees (AFSCME) and the passage of public-sector collective bargaining laws. ${ }^{79}$ Public sector union literature has been densely populated on education and primarily focuses on two broad areas: how unions affect costs and their impact on performance (which involves matters surrounding accountability and reform).

Teacher union scholarship, sufficient for its data and theory, has been successful in establishing that unions, and more specifically contracts, are one of the determinants of disadvantaged schools which struggle with accountability. ${ }^{80}$ Much of critical teacher union scholarship argues to transform the perception of teacher unions to special interest

\footnotetext{
78 Freeman and Han, 2012; Hacker and Pierson, 2010.

${ }^{79}$ Norcross, 2011.

${ }^{80}$ Moe and Anzia, 2013.
} 
groups. ${ }^{81}$ This transformation, while simple, is key in understanding how unions behave and operate. Moe claims that the vested interests of teacher unions are inherently at odds with the interests of their occupation, and the asymmetry of interests has led to unions fighting reform measures and creating protections for themselves that are not intentioned to better the system, but their members. ${ }^{82}$ This is not a feature unique to teacher unionism but can be applied to a broad range of special interests. Similarly, Keenan and Walker highlight this concept in their article on contract provisions when discussing police union interests. ${ }^{83}$ Finally, teacher union scholarship captures the political dimension and thoroughly documented union efforts to lobby against reform in the policy realm. ${ }^{84}$ This was observed by collecting data on whether unions engage in political endorsements at local levels of government. ${ }^{85}$

In sum, while establishing the relationship between misconduct and provisions, it is important to consider how politics plays a role in not only strengthening unions, but also how ideological alliances may influence police unions and their abilities. For example, a link between politics and unions has been illustrated by the fact that teacher unions heavily favour Democratic candidates. ${ }^{86}$ This has led to Moe arguing the "politics of blocking" theory, which accredits blame to the unique design of the US political system and Democratic politicians for the blocking of education reform. ${ }^{87}$ Subsequently, unionism also highlights the relationship between weak state labour laws restraining union power and conservative interests at the state and federal level. ${ }^{88}$ Furthermore, Moe argues that the American system of checks and balances creates several veto points which makes it

${ }^{81}$ Moe, 2012; Moe, 2015.

82 Moe, 2009.

${ }^{83}$ Keenan and Walker, 2005.

${ }^{84}$ Moe, 2012.

${ }^{85}$ Moe and Anzia, 2013.

${ }^{86}$ Moe, 2012.

${ }^{87}$ Moe, 2012.

${ }^{88}$ Freeman and Han, 2015; Hacker and Pierson, 2010. 
easier for teacher unions to block reforms. Furthermore, he highlights that significant reforms disrupt the existing vested interests held by teacher unions and that they use their power to continue to weaken the "efforts of reformers to bring real change." ${ }^{89}$ Later work by Moe further builds upon the idea that vested interests have "strong incentives to protect those institutions when faced with threatening reforms." 90

To summarize, as illustrated by "Figure 1", there is yet to be a study which reveals a direct link between provisions that have been argued to frustrate accountability and police abuse across a large range of American cities. Moreover, there has yet to be work on police unionism that bridges the gap between the two sub-fields focusing on problems of accountability and understanding the effect of ideological alliances.

Figure 1 Identifying the Gaps

Walker (2008)

Recognizes the lack of scholarship and the impact of police unions on discplinary procedures and community relations.

McCormick (2015)

그 Police unions are often obstacles to reforms and $\frac{7}{\sigma}$ reinforce police subculture including the "code of ט 흐 silence."

등 $\stackrel{2}{\rightleftarrows}$ Bies (2017)

Enions block reforms which increase accountability Uु and transparency via lobbying.

.ํㅡㄴ uㅜㄴ \&uq McAdams (2016)

Focuses on impact of "delay priveleges" created by police unions and how the "Blue Wall of Silence" promotes unlawful police violence

Fisk \& Richardson (2016)

Police Unions are obstacles to reform. Moreover, they demonstrate how and why unions defend officers accused of misconduct.

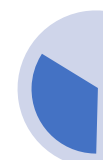

Dharmapala et al., (2017)

Collective Bargaining Powers are positively correlated with cities with more police misconduct. Doesn't identify the specific union mechanism which may continue misconduct. Argues that it

ㅇ can potentially could be contract

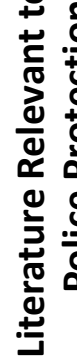

Are police union protections correlated with abuse? Can politics explain the level of police protections?

These developments in the study of teacher unions can serve as the groundwork for furthering understanding of police unionism.

${ }^{89}$ Moe, 2012, P.1.

${ }^{90}$ Moe, 2015, P. 277. 


\section{CHAPTER 3}

\section{THEORY \& HYPOTHESES}

Prior to discussing the theory proposed in this paper, it is important to justify the comparative units (100 largest cities) and scope of this thesis.

\section{Framework for Analysis}

The systemic problem of policing is not unique to the US, but a global issue. Nevertheless, differences in the magnitude and severity of policing issues in other regions make it difficult to apply theories or create strong comparative cases. For example, in the case of Brazil, it has been noted that approximately nine out of ten police killings were extrajudicial and that an estimated 3,345 civilians were killed at the hands of police in 2015 alone. ${ }^{91}$ In contrast, the Washington Post's "The Counted" database found there to be 963 deaths in $2016 .{ }^{92}$ Furthermore, the difference between centralized policing in European states coupled with more racially homogenous populations makes other western developed countries a difficult comparison. An intra-country comparison also allows for different environmental elements, such as electoral system and federal structures, to remain as a constant, which inadvertently isolates variables of interest. Thus, this study will instead focus on the largest 100 cities in the US. The 100 largest cities will account for

${ }_{91}$ Waldron, 2017.

92 The Washington Post, “The Counted” database, 2016. 
variation in abuse, union structures, and size. Instead of focusing on just one case, the 100 cities allow for the study to account for more variation in outcomes that do not apply just to cities in one state. Moreover, the autonomy given to police departments at the locallevel inherently creates a wider variation of outcomes.

To reiterate, past studies have largely failed in bringing unionism onto the quantitative stage because of methodological flaws and the employment of weak dichotomies for accountability and union power. ${ }^{93}$ Nevertheless, recent quantitative studies have recently been successful in capturing the relationship between accountability and unions. ${ }^{94}$ Finally, it is important to note that the lack of lack of data in American policing is one of the most serious problems for sufficiently testing theories across a large range of observations and this study is not immune. Hence the employment of different proxies and the creation of a new index. ${ }^{95}$

Regarding the relevance of theories and methods drawn from teacher union literature, the plethora of similarities between the two public sector unions make it an ideal comparison, especially because studies that have explored the fiscal effects of unions have returned similar findings in both occupations. Still, it is worth noting limitations between the very distinct nature of the occupations. Performance and misconduct in education can result in an ineffective education system that continues to negatively impact disadvantaged students and schools. Lack of accountability and continued abuse in policing can lead to serious injury and the death of innocent civilians. Moreover, the design of how the two publicsector unions operate vary greatly. While teacher unions are more centralized and powerful at the federal level, police unions draw their strength from de-centralization and are more

\footnotetext{
93 Wilson and Buckler, 2010.

${ }^{94}$ Rushin, 2017.; Huq and McAdams, 2016; McCormick, 2015.

${ }^{95}$ Fryer, 2017; Walker, 2008.
} 
effective at the local level because of the autonomy of chapters that exist at the department level. ${ }^{96}$ Moe touches upon the benefits teacher unions receive from the design of the American system which makes reform difficult. ${ }^{97}$ Thus, attention needs to be shifted to theories which describe unique benefits and advantages that the design of the American state offers.

To reiterate, police unions, like any special interest group, exist to advocate for their members. ${ }^{98}$ Consequently, it is natural for unions, which have a legal obligation to protect their members, to take stances against reforms that strengthen the administrative ability of the department to discipline officers or repair accountability systems. ${ }^{99}$ Teacher union scholarship emphasizes the need to view unions as special interest groups, rather than be labeled as organized labour. ${ }^{100}$ I will adopt a similar framework for this thesis. While this ontological change may be perceived to make a minute difference, it allows the field to be better informed by literature on special interests. ${ }^{101}$

\section{Theory}

Drawing from existing theories on public sector unions, special interest groups, APD and Criminology, I pose new theories which converge and build upon these four areas. ${ }^{102}$ First, the study investigates what variables explain "why" police abuse continues to run rampant by exploring an underexplored dimension in Criminology - police unionism. Second, it asks "how" police unions (also referred to as "Associations") continue to keep the status quo and insulate police abuse by focusing a key union mechanism: police union contracts

\footnotetext{
96 Juris and Feuille, 1973.

97 Moe, 2012; Moe, 2015.

98 Moe, 2012; Bies, 2017.

${ }_{99}$ Keenan and Walker, 2005; Bies, 2017.

100 Moe, 2012.

101 Miller, 2008; Baumgartner and Jones, 1993; Hacker and Pierson, 2010.

102 Mettler and Vallely, 2016.
} 
and LEOBR. It is worth noting that this argument does not consider union mechanisms as the sole or primary cause of continued police abuse. Instead it attempts to draw a linkage between police abuse.

Policing institutions in democratic societies are purposed to enforce the law fairly and equally. Thus, when a democratic institution is unfairly targeting or abusing its power on the citizenry it is expected to protect, there need to be reforms intentioned to revive democratic elements of accountability and transparency. Criminology has established the impact of unfair police practices and tactics which disproportionately affect minority groups. ${ }^{103}$ Moreover, it has illustrated how departments have failed to deter misconduct and hold their officers accountable. The majority of studies discussing police accountability operate under the premise that officers are rational actors and thus respond to deterrence practices. Thus, mechanisms which infringe on different dimensions of deterrence will have an inverse effect on misconduct. Deterrence theory serves an important role as it provides the best explanation for continued misconduct, given that we accept the view of officers as rational actors. ${ }^{104}$

Police unions have often been observed taking actions which are in principle opposed to the democratic elements of accountability and transparency. ${ }^{105}$ The purpose of police unions, from a general standpoint, is to fight for its members, and thus embedding them with their own vested interests, which may not be reflective of the community in which they serve. ${ }^{106}$ Problems of police abuse are not recent developments; rather, they are likely to have originated during the hysteria of the "War on Drugs" where questionable policing

103 Smith and Holmes, 2014

104 Pogarsky and Piquero, 2004.

105 Juris and Feuille, 1973.

106 Keenan and Walker, 2005. 
tactics were accepted, and accountability was not a priority for departments or the communities in which they served. The "War on Drugs" has been argued to have altered the status quo favouring police and prosecutors. ${ }^{107}$ While police abuse and controversial police practices may have originated during this period, it is plausible to suggest that union mechanisms have and continue to have an insulator-like effect. Thus, union mechanisms may serve as an explanation for how abuse has endured despite periods of demand for reform.

Building upon both qualitative and quantitative scholarship on police unions, I attempt to test the "culture of impunity" theory which argues that greater police protections are likely to exist in cities with greater police abuse. ${ }^{108}$ In other words, continued abuse is the result of contract protections which reduce deterrent effects and in turn construct an atmosphere where officers are more likely to commit misconduct because of the lack of consequences. ${ }^{109}$ Contract protections which weaken accountability systems and safeguard officers who commit misconduct.

Existing scholarship on police union contracts and LEOBR is used as a framework to identify different contract provisions which safeguard officers from accountability. ${ }^{110}$ Provisions are then compiled into an index where each city receives a different score which represents the level of police protections. In essence, the index of police protections represents how little or large of a deterrent effect exists on officers. This will then be applied to a large-N study of America's largest 100 cities to determine whether greater level of protections have a significant relationship with police abuse. Relevant independent and control variables which have been established in past studies as determinants of police

\footnotetext{
107 Miller, 2008; Baumgartner, True and Jones, 2006.

108 Walker, 2016.

109 Ibid.

110 Walker, 2008.; Keenan and Walker, 2005.; Rushin, 2017.; Huq and McAdams, 2016.; Dharmapala, et al, 2017.
} 
abuse such as Minority Threat and Spatial variables will be included. I hypothesize the following theories which are presented in Table 1.

Table 1 Hypotheses

\begin{tabular}{lll}
\hline & \multicolumn{1}{c}{ HYPOTHESES } \\
\hline Hypothesis 1 & Quantitative & $\begin{array}{l}\text { Police protections (IV) are positively correlated with greater } \\
\text { levels of police abuse (DV). }\end{array}$ \\
\hline Hypothesis 2 & Quantitative & $\begin{array}{l}\text { Police protections (IV) and cities with larger } \\
\text { populations/densities of Black/Hispanic groups (IVs) are } \\
\text { positively correlated with greater levels of police abuse } \\
\text { (DV). }\end{array}$ \\
\hline Hypothesis 3 & Quantitative & $\begin{array}{l}\text { City level conservatism (IV) is positively correlated with } \\
\text { higher levels of police protections(DV). }\end{array}$ \\
\hline Hypothesis 4 & Quantitative & $\begin{array}{l}\text { State level conservatism (IV) vis-à-vis state labour laws } \\
\text { and bargaining rights are negatively correlated with } \\
\text { greater levels of police protections (DV). }\end{array}$ \\
\hline IV = Independent Variable & DV = Dependent Variable \\
\hline
\end{tabular}

First, I argue that greater levels of police protections (independent variable), found in union contracts, are positively correlated with greater levels of police abuse (dependent variable). I also predict there to be a stronger relationship when including race-relevant and other institutional variables as co-variates.

Subsequently, the study will briefly explore what variables can explain the level of police protections. As noted earlier, scholarship on police unionism fails to include political variables, which is the second question this thesis seeks to answer. Consistent with other literature that identifies relationships between public-sector unions and political parties in the United States (such as fire and teacher unions), I explore whether the local-level ideology and statelevel ideology have any bearing on obtaining stronger protections. Police officers and their unions tend to "...frequent police-union endorsement of, or informal membership for, political candidates who exhibit conservative stances on many social and political issues.” ${ }^{111}$

111 Juris and Feuille, 1973. 
Developments in recent years have shined a light on the strong social link and loyalty between members of the law enforcement community and the Republican party. ${ }^{112}$ Moreover, advocacy groups have recognized the "double standard" held for police unions by conservatives. ${ }^{113}$ While conservatives focus their attacks on teacher unions, they also appear to defend and support police unions. ${ }^{114}$ This leads to the next hypothesis, which is that police unions in more conservative cities are likely to have a positive relationship with police protections. Literature and observations on officer perceptions would predict a positive correlation between police protections and cities which are more conservative. Alternatively, union scholarship finds that conservative ideology has a negative impact on labour and union power. ${ }^{115}$ To reiterate, teacher union scholarship finds that ideological alliances between the Democratic party and unions resulted in the creation of favourable labour laws at the state and federal levels of government. ${ }^{116}$ Furthermore, path dependency and union literature has confirmed a link between restrictive state labour laws restraining union powers and conservative states. ${ }^{117}$ Thus, I expect state level ideology reflected vis-à-vis labour laws to restrain or weaken union powers, and in turn, have a negative relationship with police protections. The political dimension explored in this paper will be critical in shedding light on confirming or discounting theories surrounding ideological alliances. The liberal ideology employed by the Democratic party favours unions, whereas American conservatism holds strong anti-union views and has steadily been reducing union power over the last few decades, most notably, focusing attacks on teacher unions. ${ }^{118}$ In addition, it will either confirm or nuance Moe's argument surrounding the politics of blocking and how some unions may benefit from conservative support and not exclusively from liberal support.

\footnotetext{
112 Ibid.

113 Quick, 2017.

114 Ibid.

115 Freeman and Han, 2015; Hacker and Pierson, 2010.

116 Moe, 2012; Dark, 1999.

117 Hacker and Pierson, 2010; Wilson, 2016.

118 Hacker and Pierson, 2010, McCartin, 2011; Freeman and Han, 2015.
} 
Table 2 Alternative Explanations

\begin{tabular}{lll}
\hline & \multicolumn{2}{c}{ ALTERNATIVE EXPLANATIONS } \\
\hline Alternative 1 & Qualitative & $\begin{array}{l}\text { Police unions are restrained in their ability to maintain the } \\
\text { status quo when competing with ethnic unions that have } \\
\text { interests to reform the status quo. }\end{array}$ \\
\hline Alternative 2 & Qualitative & $\begin{array}{l}\text { Police unions have difficulty preserving the status quo in } \\
\text { states with weak labour laws and progressive reformers at } \\
\text { the city-level. }\end{array}$ \\
\hline
\end{tabular}

Following the primary quantitative models, the final part of paper will qualitatively explore alternative explanations for how union structures can continue abuse or help in reforming departments. This is illustrated by employing a comparative case study approach between the cities of Chicago, Illinois, and Dallas, Texas: the former union with considerable collective bargaining power and the latter wielding weaker leveraging powers. In essence, the qualitative study will illustrate that unions can also rely on other mechanisms that reduce deterrence and safeguard police behavior (Table 2). Interviews with police officers, union representatives, city representatives, news clippings and relevant union literature used to identify different union mechanisms insulating police culture will be discussed. Other types of qualitative evidence will include news clippings, lawsuits and press statements. The differences in union structures between the two cities coupled with differences in labour landscapes such as competing unionism or weak labour laws may provide additional explanations for why some unions are more effective in insulating abuse, and others are more accepting of reforms that disrupt the status quo. 


\section{How Police Unions Insulate Abuse}

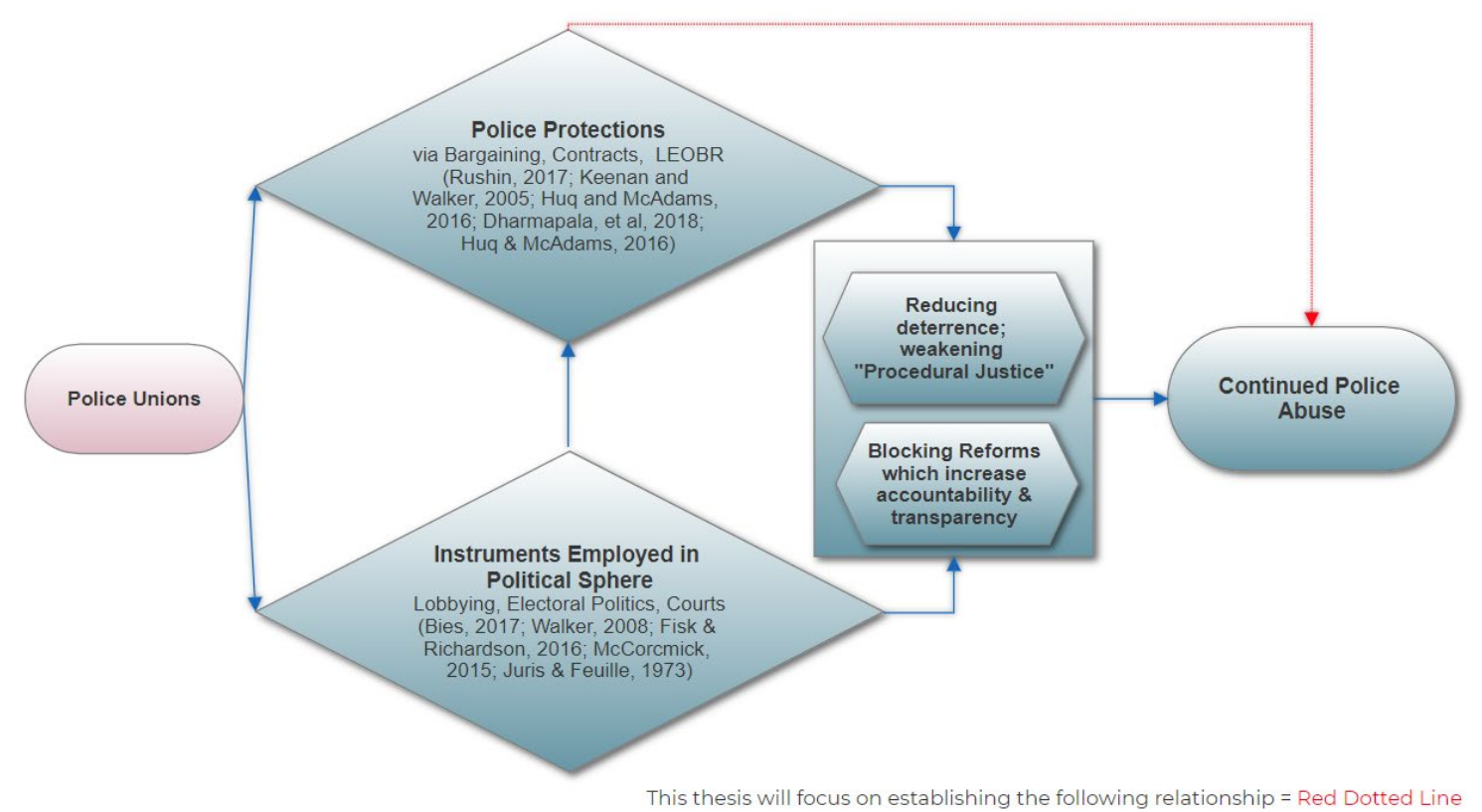

Figure 2 Causal story

This thesis, as illustrated in "Figure 2", is testing the relationship illustrated by the red dotted line connecting police protections to police abuse. First, I establish that variation in police abuse can, in part, be explained by specific types of union contract protections which are intentioned to reduce deterrence and create ineffective accountability systems. Subsequently, I explore whether political variables can best explain the ability of unions to create police protections. Next, I will qualitatively explore additional factors and analyze other union mechanisms which can be used to insulate abuse and maintain the status quo. Political actions may also help expand union power and can combat reforms aimed at repairing problems of accountability and transparency. While the blocking of reforms and political actions have been established to be an important area to explore, it will not be thoroughly investigated in this paper as it is beyond the scope of this thesis, which is primarily focused on the role of union contract protections. 
To summarize, the primary purpose of this paper is to establish the importance of police unionism in insulating abuse by quantifying the impact of a key union mechanism: police protections. The contribution of the police protection index will be a significant advancement in better understanding the relationship between unionism and problems with policing in America. Second, it aims to fill the apolitical void surrounding police unionism literature and establish that ideological alliances either strengthen or restrain police unions' abilities to insulate abuse and maintain the status quo. The qualitative section is purposed to create a more rigorous study which confirms the role of unions insulating abuse but also explores additional factors and aspects of unionism which insulate abuse.

\section{Mixed Methods Framework}

These hypotheses will not exclusively be tested in either a qualitative or quantitative approach; rather, it will be using both methods to provide a more rigorous study. The strengths of each method will counter-balance the weaknesses of the other. Additionally, recent developments in social science methods have illustrated the value of a mixed method approach. ${ }^{119}$ As touched upon in the literature review, quantitative studies on policing have failed to sufficiently explain the effects of different mechanisms created by unions. For example, one issue with quantitative studies in the past was the lack of a qualitative study to explain the effects of different mechanisms created by unions. It is difficult to quantify the power of unions with existing data as suggested by previous studies. ${ }^{120}$ This only further highlights the need for a qualitative study to better explain the role unions play. While quantitative methods may be better suited to "produce the final

\footnotetext{
119 Jick, 1979

120 Moe, 2009.
} 
inference," qualitative case studies may be more appropriate for confirming its proposed causal mechanisms. ${ }^{121}$

\section{Disclaimers}

First, I recognize that readers may take issue with facts and/or interpretation of the data as they read this work. This is inevitable when dealing with a large amount of both qualitative and quantitative data. The questions I have asked regarding the qualitative data, especially, were reflective of my interpretation of the interviewees' responses. There was a total of 15 interviews: 10 officer interviews, 4 city hall/city council representatives, and 1 appointed federal actor. ${ }^{122}$ Interviews were obtained via a 'snowball' process by contacting the largest unions in both cities and contacting the offices of city hall and city representatives.

Second, I promised anonymity to the participants of the study in return for their cooperation. ${ }^{123}$ This was a requirement for many of the participants involved, especially city representatives and police officers who may face professional consequences from their participation whether it be re-election or officer retaliation. I anonymize the identity of interview subjects, using phrases such as "An elected/appointed city representative" or "a Chicago Police Officer/union member" Third, the questions asked in each interview were adjusted to the subject's background, experience, nature of job and geography. Thus, the interviews were not all uniform in their style and formatting which is why the findings were not presented in some type of visual such as a chart that presents a breakdown of the responses. Finally, extreme care should be exercised in generalizing the qualitative evidence in this study. Qualitative evidence from the interviews from the two cities which the subsequent chapter will focus on will be used to test the existence of alternative mechanisms

\footnotetext{
121 Seawright, 2016, P. 171.

122 Appendix $K$ includes information date of interviews conducted as well as their position.

123 This is true for all interviewees with the exception of the federal perspective, Jonathan Smith.
} 
of how police departments protect officers and show qualitative evidence of how the contracts could work in practice. There is a danger with extrapolating political perceptions from a handful of interviews from only two cities in a 100-city dataset.

These findings do, however, inform the study about how unions engage in political activities and employ other mechanisms to help achieve their goals and to either improve their position or maintain the status quo. 


\section{CHAPTER 4}

\section{DATA \& CONSTRUCTION OF INDEX OF POLICE PROTECTIONS}

The following section describes a quantitative model I created to explore the relationship between union contract protections and police abuse. The model and subsequent analysis seek to answer the following question: do cities with greater levels of police protections (independent variable) experience higher levels of police abuse (dependent variable)?

\section{Context of Data in American Criminology}

A nationwide database on policing does not exist in the United States. American criminologists who study policing agree that the lack of uniform data makes it difficult to identify with any degree of certainty the key variables that determine policing outcomes in the US. ${ }^{124}$ However, efforts are underway to fill this void. For example, California is currently conducting a pilot program which collects data regarding excessive police force and other relevant misconduct variables across all state law enforcement agencies. ${ }^{125}$ While some cities and states have required the police department to keep more open and accessible systems to police data, no data is available for the majority of departments and what is collected is not uniform between those departments that do have some type of open access system. Former Federal Bureau of Investigation Director James Comey stressed the need

${ }^{124}$ Walker, 2008

125 Neuhauser, 2016. 
for the USA to develop a uniform database which collects data on variables capturing misconduct/abuse:

"How can we address concerns about 'use of force,' how can we address concerns about officer-involved shootings if we do not have a reliable grasp on the demographics and circumstances of those incidents? We simply must improve the way we collect and analyze data to see the true nature of what's happening in all of our communities." 126

The lack of uniform and credible data available for research cannot be understated. Moreover, one of the ironies of this paper is that the lack of uniform data is in part due to the highly effective strategies employed by unions at the local-level to file lawsuits and pressure politicians to fight against data collection policies. ${ }^{127}$

\section{Data}

This study aims to fill the void of missing data in policing by constructing a variable to shed light on a previously underexplored area - police unionism. I constructed an original dataset consisting of 100 observations that represent police departments in America's largest cities. ${ }^{128}$ The variables which comprise the dataset are drawn from the following sources: U.S. Census Bureau, Campaign Zero's Mapping Police Violence, Campaign Zero's Police Union Contract Database, Campaign Zero's Use-Of-Force dataset, Law Enforcement Management and Administrative Survey (LEMAS) 2013 and an originally constructed variable of police protections.

Campaign Zero, an advocacy group and police reform campaign that aims to obtain policing data, created the "Mapping Police Violence" database which combines data from three of the largest police-related deaths databases: FatalEncounters.org, KilledbyPolice.net and The Washington Post's "U.S. Police Shootings Database." ${ }^{129}$ The authors of the database

126 Comey, 2015.

127 Walker, 2008; Bies, 2017.

128100 largest cities listed in Appendix A.

${ }^{129}$ Campaign Zero, "Mapping Police Violence Dataset", 2016. 
obtained the remainder of the data via extensive research and web scraping. They argue that they have captured 98 percent of police related deaths since $2013 .{ }^{130}$ It consists of 5,577 observations of individuals who have been killed by members of the US Law Enforcement community from 2013.

In addition to obtaining data on police killings, Campaign Zero's police union contract database compiles a large range of problematic provisions from union contracts which are potential impediments to accountability. ${ }^{131}$ I have analyzed each provision in the dataset and have placed them into different categories to create an index of "police protections." A number of provisions were excluded which did not fit the criteria, meanwhile, several other provisions were added which were not in the database by using a word phishing algorithm. ${ }^{132}$ Campaign Zero's use of force dataset will also be employed which includes an index of use of force policies on America's largest 100 cities. ${ }^{133}$

The LEMAS, administered by the Bureau of Justice Statistics and operating under the US DOJ, contains survey data on 3,272 law enforcement agencies around the country. ${ }^{134}$ The survey is issued every seven years, and the most recent survey conducted in 2012 observed 360 variables characterizing the department.

\section{Dependent Variable}

The dependent variable, police abuse, is measured as the number of police killings of unarmed civilians or civilians who were not wielding a "deadly weapon" for the purposes of this paper, while 'abuse' and 'misconduct' capture similar concepts, I will be employing the term 'abuse.' Ideal data which would best test the theory is uniform excessive use of force data.

\footnotetext{
130 Campaign Zero, "Mapping Police Violence Dataset”, 2016.

131 Campaign Zero, "Police Union Contract Database", 2016.

132 Appendix $B$ includes information and details on the python word phishing algorithms written to identify additional provisions not identified by the "Police Union Contract" dataset.

133 Campaign Zero, "Use of Force Data", 2017. This dataset is not public was obtained with permission from Campaign Zero.

134 US DOJ, “LEMAS Dataset”, 2013.
} 
Unfortunately, this is not yet available. ${ }^{135}$ Police abuse should not only constitute deaths of civilians; rather, abuse is encompassing of minor incident of police misconduct and incidents of excessive use of force. Employing deaths as a proxy for abuse is admittedly an extreme proxy, hence its limited range and variation across cities. Thus, while this may be viewed as an imperfect metric for reasons surrounding the relativity of how one classifies "police abuse," I will argue in the following section (and in Appendix C) that it is sufficient in testing the hypotheses.

The "Mapping Police Violence" dataset codifies deaths of civilians by police officers into "allegedly armed," "unclear," "vehicle” or "unarmed." "136 For the purposes of this study, I have filtered the observations down to "unarmed," removed "vehicle" deaths, and have removed "allegedly armed" cases involving civilians wielding a "deadly weapon" to represent police abuse. Observations where the individual was confirmed to be unarmed constitutes a case that involves some type of police abuse. Police-related deaths of "allegedly armed" civilians are more difficult to be argued as abuse. Cases of armed deaths which involve an individual possessing a "deadly weapon" have been excluded. ${ }^{137}$ Cases where a "deadly weapon" is not being wielded is not a perfect proxy for police abuse but is sufficient for the purposes of testing the theory in this study. Nonetheless, the clear majority of the "armed" observations were removed since the individual may have been wielding a firearm, knife or another deadly weapon.

This filtered down the observations to 314 occurrences of civilian deaths and 1,508 instances of armed deaths across America's largest 100 cities between 2013 and 2016. Deaths such as suicide, vehicular death, and incidents of a similar nature have been excluded. Additionally,

\footnotetext{
135 The ideal dataset to test this theory would be uniform 'excessive use of force' data across cities, however, this data is not yet available and will be discussed later in depth. This data should become available in coming years, and there has been developments and initiatives made by individual states.

136 Campaign Zero, "Mapping Police Violence" Dataset, 2016.

137 "Deadly Weapon Law and Legal Definition", US Legal, n.d.
} 
it is problematic to generalize every "Allegedly Armed" case as "abuse," but to resolve this issue a more in-depth analysis would have to be applied, which is beyond the scope of this study. The justification, steps, and different filters applied to create the primary dependent variable of police abuse can be found in Appendix $C$.

Incidents with deadly use of force can be argued to characterize abuse. The standard for deadly use of force can be extrapolated from the Tennessee v. Garner Supreme Court ruling in 1985 , which stated that "deadly force...may not be used unless necessary to prevent the escape and the officer has probable cause to believe that the suspect poses a significant threat of death or serious bodily harm to the officer or others." ${ }^{138}$ Moreover, it is difficult to argue that a situation in which individuals who are unarmed or are not wielding a "deadly weapon" are facing a trained law enforcement officer constitutes a case of the officer confronting a deadly threat. Thus, while it is not a perfect proxy for abuse, I define abuse in this study as such and acknowledge its limitations. Appendix $C$ provides a more in-depth discussion and justification for the police abuse variable construction.

Furthermore, only deaths of unarmed civilians or civilians without a "deadly weapon" at the hands of on-duty officers have been included. Off-duty police officers have been excluded because police protections apply only to officers who are on the job.

\section{Independent Variable: Index of Police Protections}

As noted earlier, this study's primary independent variable, police protections, will be an index comprising union contract and LEOBR provisions argued to create problems for accountability and reduce deterrence. This rigorous process required individual analysis and consideration of union contract and LEOBR provisions for each city. ${ }^{139}$

\footnotetext{
138 Tennessee v. Garner, 1985. US. Supreme Court.

139 Please see Appendix E for more information on codification.
} 
This study is the first attempt to construct a broad index of police protections for America's largest police departments. Thus, its findings can shed light on a previously unexplored area of American criminology: the relationship between abuse and police protections. First, I will identify the different categories of provisions which have been argued to reduce deterrence and frustrate accountability. Subsequently, I will explain the rationale and provide an example of union contract provisions which suit the criteria.

The codification of text has been a significant methodological development in the social sciences which inherently combines elements of both qualitative and quantitative approaches. ${ }^{140}$ Text codification has frequently been used in studies involving public-sector unions, which is why I chose to adopt this methodological approach for my study. ${ }^{141}$ Similarly, this study will attempt to construct an index for police protections by codifying union contracts and LEOBR, which reduce accountability and deterrence. The category of provisions being used to construct the index have been found in existing qualitative studies to frustrate accountability and reduce deterrence. ${ }^{142}$ In sum, this index will indicate the level of protections offered to police officers. Some scholars refer to these protections which reduce accountability as "problematic." 143

I obtained union contracts and LEOBR provisions for America's largest 100 cities from Campaign Zero's police union contract database. Sixteen cities do not have contracts and 3 have refused to send a contract. ${ }^{144}$ Fourteen states with LEOBR have been included into the codification. ${ }^{145}$ LEOBR are created by the state but can be viewed as extensions of union contracts since unions across the state lobby together for state legislation. ${ }^{146}$ Contracts that have been renewed since the completion of Campaign Zero's database have been checked for

\footnotetext{
140 Grimmer and Stewart, 2013.

141 Moe, 2009.

142 Keenan and Walker, 2005.

143 Rushin, 2017.

144 Appendix $D$ includes information on cities without contracts.

145 Juris and Feuille, 1973. States with LEOBR's can be found in Appendix D.

146 Ibid.
} 
the addition or removal of provisions pertinent to the construction of this index. Thus, the protections for the period of this study are static and do not vary temporally. Nevertheless, it is worth noting that the addition or removal of contract provisions, specifically protections, are largely “a rare occurrence." 147

The justifications are largely drawn from legal and qualitative studies evaluating the impact of contract provisions. ${ }^{148} \mathrm{I}$ have identified provisions which fall into one of the following categories for the purposes of this study in Table 3.

Table 3 Category of Provisions

\begin{tabular}{ll}
\hline Limiting Oversight \\
Reducing/Preventing Oversight \\
Of & Statutes of Limitations on Data Retention \& Use (Unsustained) \\
Provisions & Statutes of Limitations on Data Retention \& Use (Sustained) \\
& Requiring City to Pay for Legal Costs and Indemnification \\
& Restrictions on Non-Sworn Investigators \\
& Unfair Access to Investigative Materials (Full) \\
& Unfair Access to Investigative Materials (Partial) \\
& Statutes of Limitations on Filing of Complaint \\
& Limitations on Type of Complaint \\
& Formal Waiting Periods that Delay Investigations \\
& Limiting Transparency \\
Advantages in Disciplinary Action
\end{tabular}

Before discussing the methods and weights for the provisions, I will first identify and justify why they have been selected. ${ }^{149}$

\footnotetext{
147 Walker, 2008; Keenan and Walker, 2008.

148 McKesson, Packnett, and Sinyangwe, 2016; Walker, 2008; Keenan and Walker, 2005; Rushin, 2017; Huq and McAdams, 2016; Dharmapala, et al, 2017.

149 Appendix E discusses the methods and steps taken to codify the contracts including visuals of the process.
} 


\section{Limiting Oversight}

As discussed earlier, oversight entities that are not restricted or have the capacity to make decisions have been identified as a strong determinant of an accountable department. ${ }^{150}$

Provisions that reduce civilian oversight are frequently found in the contracts studies and are a serious burden to creating accountable police departments. One study found that only $6 \%$ of officers supported the authority for civilian review boards to investigate matters. ${ }^{151}$ Provisions that reduce civilian oversight can make oversight committees virtually powerless and ineffective. The absence of civilian oversight is self-oversight, where the board is composed of a body of peers. The lack of transparency or involvement of civilian actors in disciplinary investigations can make these boards vulnerable to peer pressure. ${ }^{152}$ This is a common problem found in self-oversight which critics have labelled as the "The Blue Wall of Silence." 153 Thus, strong and autonomous external bodies which have the power to conduct thorough investigations and issue recommendations are found to be more effective in improving police-community relations and forces departments to conduct thorough investigations of misconduct. ${ }^{154}$

This category includes oversight entities which are limited in their capacity to subpoena, interrogate officers, participate or are restricted from conducting a thorough investigation. An example is found in the Austin police contract:

"Citizen Oversight ... regardless of its name or structure, shall not be used or permitted to gather evidence, contact or interview witnesses, or otherwise independently investigate a complaint of misconduct by an Officer. There shall be no legal or administrative requirement, to subpoena power or ...that an Officer appear before or present evidence to any ... Citizen Oversight." 155

\footnotetext{
150 Powers and Rosenblatt, 2001; Walker, 2001.

151 Wells and Schaeffer, 2007.

152 Bobb 2003; Greene, 2007.

153 Huq and McAdams, 2016.

154 Finn, 2001; Green, 2007; Philips and Trone 2002.

155 Campaign Zero, "Police Union Contract Database", 2016. [Austin, TX. Police Union Contract.]
} 
This provision bars the oversight board from issuing subpoenas to officers and strips an important instrument from the civilian investigators. In sum, it makes it difficult for the entity to present a strong case against the officer in question, thus, reducing the fear of consequence for the officer.

\section{Reducing/Preventing Oversight}

A provision which would constitute reducing or preventing any civilian oversight entity would constitute the following language found in the St. Paul contract:

"A civilian review board, commission, or other oversight body shall not have the authority to make a finding of fact or determination regarding a complaint against an officer or impose discipline on an officer." 156

Should the provision make the civilian review board essentially powerless or restrict participation, then the provision is categorized as a high-level protection. In this instance, the St. Paul union contract prevents the civilian oversight board from issuing a finding or disputing a complaint.

There are numerous documented cases of unions expressing opposition to civilian oversight or hollowing out their investigative abilities via lawsuits, political pressure or contract protections. ${ }^{157}$

\section{Statutes of Limitations on Data Retention \& Use (Unsustained)}

The next category discusses provisions which institute statutes of limitations on data retention and use. Some contracts and LEOBR prevent departments from keeping or revealing officer discipline and complaint history. These types of provisions do not apply only to civilian oversight entities, but also to internal department investigations. This makes it difficult not only for civilian review boards but also for departments attempting to discipline or terminate officers. These provisions include actions which instruct the

\footnotetext{
156 Campaign Zero, "Police Union Contract Database", 2016. [St. Paul, MN. Police Union Contract.] 157 Walker 2001; Tal 2003.
} 
department or city to: (1) delete disciplinary history or complaints after a certain period; (2) delete disciplinary history or complaints upon discretion of a supervisory officer; or (3) delete sustained complaints and other actions of a similar nature.

I have classified provisions of this nature into two dimensions. Low-level provisions consist of protections that may delete officer history over long periods of time or only erase unsustained complaints. A Hialeah contract provision would fall under this category of provisions:

"Any employee of this bargaining unit who is the subject of an internal investigation or review board will have the right to have all documents and reports purged from his personnel file if he is found to be not guilty." 158

The erasure of sustained complaints is clearly problematic because it represents cases where officers were found guilty of wrongful conduct. However, erasing unsustained complaints is also problematic: the lack of a complaint history makes it difficult to establish patterns of bias or misconduct.

\section{Statutes of Limitations on Data Retention \& Use (Sustained)}

A high-level protection would include provisions that contain language which forces the department to erase sustained complaints or prevents the use of complaint history in newly opened investigations. The following provision is found in the Sacramento contract:

"Documented disciplinary actions, or other related adverse documented comments entered in the employee's Office file, shall be removed from the Office file after one year from the date of documentation." 159

These provisions should be of greater concern for its potential role in insulating police abuse.

It is apparent the impact that such a provision can have on reducing deterrence and accountability. Moreover, Walker and Rushin argue that these limitations on data retention

${ }^{158}$ Campaign Zero, "Police Union Contract Database", 2016. [Hialeah, FL. Police Union Contract.]
${ }^{159}$ Campaign Zero, "Police Union Contract Database", 2016. [Sacramento, CA. Police Union Contract.] 
and use are hurtful to Early Intervention Systems (EIS), which Walker argues to be one of the most innovative and important accountability mechanisms. ${ }^{160}$

\section{Requiring City to Pay for Legal Costs and Indemnification}

Civil rights doctrine - 42 U.S.C. $\int 1983$ - assumes that police officers are left with the responsibility to pay settlements at their own expense. ${ }^{161}$ This is intended to deter abusive conduct: an officer is less likely to commit misconduct or abuse their power if they are cognizant of the liability for the compensation.

However, a recent study found that between 2006 and 2011, officers personally contributed financially to $0.41 \%$ of the 9225 civil rights claims in the nation's 44 largest police departments. ${ }^{162}$ Schwartz argues that her findings "undermine assumptions of financial responsibility relied upon in civil rights doctrine." ${ }^{163}$ Because of qualified immunity, an exception that is frequently used to place liability on the city, and union contracts, which mandate the city to pay for legal costs and settlements, there seems to be no financial pressure to create a deterrent effect on the officer. Thus, union contracts where the costs of settlements or legal fees fall onto the city are problematic and are a serious impediment in keeping officers accountable. An example is as follows:

“... indemnification will also be provided to any member of the unit who is made a defendant in litigation arising out of acts within the scope of his or her employment." 164

\section{Requiring City to Pay for Suspension/Fees}

This is a difficult provision to qualify, as many employers would be expected to pay for their employees' time when they have not been proven guilty of any action. However, the lack of

\footnotetext{
160 Rushin, 2017; Keenan and Walker, 2005.

161 Schwartz, 2014, P. 890.

162 Ibid.

163 Ibid.

164 Campaign Zero, "Police Union Contract Database”, 2016. [Baltimore, MD. Police Union Contract.]
} 
financial responsibility, as noted above, mitigates the deterrent effect. The following provision from the Milwaukee contract constitutes an example:

"In addition, the member shall also be served with a notice informing them of their option to substitute discretionary time in place of any or all suspension days. Suspensions exceeding five days shall not be eligible for substitution." ${ }^{165}$

\section{Restrictions on Non-Sworn Investigators}

A restriction on non-sworn investigators is a serious impediment that can reduce deterrence. This protection overlaps with concerns related to civilian oversight and problems with officers being judged by their fellow peers, rather than by an independent member who is objective and has no history or loyalty to the police force. As discussed earlier, situations where officers may be pressured by peers to protect their fellow officers are more prevalent in these settings where there are no external members to review the decisions and conduct thorough investigations. Some cities like Baltimore prevent non-sworn investigators from having any voting power:

"No civilians other than an Administrative Law Judge may serve on a Departmental Hearing Board... The AU ... will not be a voting member of the panel during deliberations on verdict or sentencing. In no event shall an AU be appointed to a Departmental Hearing Board without the consent of the accused employee or his/her counsel of record." 166

This provision stipulates that the only non-sworn member is virtually powerless - ensuring that the officer who is being disciplined will only be judged by a panel of his/her peers.

\section{Unfair Access to Investigative Materials (Full Access)}

Rushin renders a scenario where a suspect has the same type of access to an investigative file that an officer has prior to an interrogation. ${ }^{167} \mathrm{He}$ argues that most officers would view it as a constraint in carrying out a thorough investigation. Officers are likely to make a claim

\footnotetext{
165 Campaign Zero, "Police Union Contract Database", 2016. [Milwaukee, WI. Police Union Contract] 166 Campaign Zero, "Police Union Contract Database", 2016. [Baltimore, MD. Police Union Contract.] 167 Rushin, 2017.
} 
that such access "would make it unreasonably difficult to elicit [an] incriminating statement." ${ }^{168}$ Nevertheless, this protection runs contradictory to what has been argued to be "best practices" for investigators. ${ }^{169}$ The following provision was found in the Tampa Bay contract:

"The officer who is the subject of the complaint may review the complaint and all statements regardless of form made by the complainant and witnesses and all existing evidence immediately before beginning the investigative interview." 170

Another concern is that there is a possibility that police officers intimidate complainants from filing complaints, or otherwise coerce them into withdrawing complaints. ${ }^{171}$ Collins argues that complainants "may be dissuaded from filing a complaint by threats or other tactics." 172

\section{Limitations on Filing of Complaint}

Provisions of this nature touch upon two different areas. One focuses on temporal constraints on filing a complaint, whereas, the other focuses on restrictions on the type of complaint.

An example of provisions with a temporal constraint is found in the Columbus contract:

"The investigation of citizen complaints shall be concluded within ninety (90) days after the date the complaint was received by the City. This deadline may be extended by the Lodge upon written request from the City." ${ }^{173}$

Rushin admits that, while there is a benefit to keeping temporal constraints on filing complaints, it can be problematic when approaching "egregious" incidents where information is discovered at a later period. ${ }^{174}$ An example of an "egregious" incident he cites is the "midnight crew," a group of Chicago police officers who were active between 1972 -

\footnotetext{
168 Rushin, 2017, P. 1224.

${ }^{169}$ Keenan and Walker, 2005; Walker, 2008; Gupta, 2017.

170 Campaign Zero, "Police Union Contract Database", 2016. [Tampa Bay, FL. Police Union Contract.]

171 Collins, 1998, P. 180.; Keenan and Walker, 2005.

172 Collins, 1998, P. 180.; Keenan and Walker, 2005.

173 Campaign Zero, "Police Union Contract Database", 2016. [Columbus, OH. Police Union Contract.]

174 Rushin, 2017.
} 
1991. They were known to torture civilians and administer electric shocks and other torture techniques. ${ }^{175}$ Unfortunately, the evidence did not surface until after the statute of limitations had passed which prevented the police department from further investigating the officers involved. ${ }^{176}$

Another restriction involves the filing of anonymous complaints which is often cited as a strong deterrent for civilians who are afraid to make themselves known. ${ }^{177}$ Specifically, complaints that involve police brutality are more likely to be associated with a fear of retribution and prevent civilians from coming forward.

\section{Formal Waiting Periods that Delay Investigations}

Formal waiting periods are considered by several criminologists to be one of the most serious impediments. Huq and McAdams dedicate a study solely to the impact of waiting periods, which they term "delay privileges," and highlight the serious risk they pose. The San Diego contract includes the following provision:

"Any officer or officers under investigation will receive at least three (3) working days' notice prior to an interrogation except where a delay will hamper the gathering of evidence as determined by an Assistant Chief." ${ }^{178}$

Keenan and Walker argue that "delays in investigations allow officers time to collude to create a consistent, exculpatory story." ${ }^{179}$ Similarly, Rushin highlights that the extra time permitted to consult with attorneys, in combination with other protections (particularly, full access to investigative materials) can impede efforts to on keep officers accountable. ${ }^{180}$

175 Rushin, 2017.

176 Ibid.

177 Keenan and Walker, 2005.

178 Campaign Zero, "Police Union Contract Database", 2016. [San Diego, CA. Police Union Contract.]

179 Keenan and Walker, 2005, P. 212.

180 Rushin, 2017. 


\section{Limiting Transparency}

Protections that reduce transparency in department procedures are also worth including. These provisions, while reasonable, can involve crippling oversight. Alternatively, union leaders will argue that this protection prevents investigators from taking advantage of officers. Unions will argue that transparent disciplinary procedures could reduce efficiency. ${ }^{181}$ Moreover, it can lead to the department "pandering to constituents during public hearings, rather than engaging in frank discussions about the complex array of issues at stake." ${ }^{182}$ A Bakersfield contract provision falls under this category:

"The mediator shall make no public recommendations nor shall there be any public disclosure of mediation discussions in further proceedings in the grievance procedure." 183

Provisions which limit transparency to the public inherently reduce accountability since they make it difficult to assess some of the problems that may plague investigations. It is important, in accordance with "best practices" of investigations, to conduct an open and transparent investigation. ${ }^{184}$

\section{Arbitrating Disciplinary Actions}

The clear majority of contracts include arbitration clauses: allowing officers to resolve disputes outside of the courtroom. The broader legitimacy of arbitration as an alternative dispute resolution mechanism is not in question. ${ }^{185}$ Rather, the use of arbitration, specifically as a disciplinary tool, has been documented and argued to be a serious impediment to accountability. ${ }^{186}$ This is primarily because it has been demonstrated that arbitration often leads to less disciplinary penalties. ${ }^{187}$ The Detroit contract includes the following provision:

\footnotetext{
181 Rushin, 2017.

182 Rushin, 2017, P. 1249.

183 Campaign Zero, "Police Union Contract Database", 2016. [Bakersfield, CA. Police Union Contract.]

184 Walker, 2008.

185 Rushin, 2017.

186 Ibid.

187 Armstrong, 2000; Rushin, 2017.
} 
"The disciplinary action must be appealed to arbitration by providing written notice to the Department within seven (7) days of the date of the decision resulting from the Chief's Hearing. Any information requests shall accompany the request to arbitrate." 188

Furthermore, the decisions reached in arbitration are final and cannot be overturned by a court, even if the arbitrator is "wrong on the facts and wrong on the law." 189 There are limitations with generalizing all provisions in this category under the same umbrella. ${ }^{190}$

\section{Discussion of Index}

The categories of police protections found in union contracts which have been identified and discussed above are used to construct the index. Moreover, it is worth noting that these protections do not relate to one specific area of policing. Instead, the index provides a more comprehensive image of police protections. In other words, the index encompasses provisions that impact a range of police activities including both internal and external investigations. While the lack of a distinction prevents the study from isolating the effects on a specific area, it also allows the study to better investigate the range of protections that can be coupled together to reduce deterrence. For example, unusual interrogation protections may not be serious impediments; however, when they are coupled with formal waiting periods, forcing the city to pay for legal fees and restrictions on non-sworn investigators, it projects a better image of how provisions interact with one another to reduce the deterrent effect. Some of these protections have been argued to be more effective in reducing deterrence when they exist together. Rushin provides a hypothetical which better illustrates this concept:

"Imagine if, prior to conducting interrogations, police officers were required to provide suspects and their attorneys with a full and truthful accounting of all the evidence against them. And imagine if police were required to provide all suspects and their attorneys with advance notice-anywhere from twenty-four hours to ten days in length-before conducting interrogations." 191

\footnotetext{
188 Campaign Zero, "Police Union Contract Database", 2016. [Detroit, MI. Police Union Contract.]

189 Steelworkers v. Enter Wheel \& Car Corp., 363 U.S. 593, 596 (1960)

190 A quick legal note, some arbitrations decisions are not binding. Most states limit the judicial review of arbitration decisions on appeal, thus making them effectively binding. But some localities do make arbitration decisions fully reviewable by city managers, city councils, etc. (these options are normally available in places like California and Arizona, though, and they are admittedly a rarity).

191 Rushin, 2017, P. 1224-1225.
} 
In essence, all of these protections contribute to reducing deterrence by lowering the risk of punishment. This index is important because it can be used to determine which variables are correlated alongside protections that reduce deterrence.

\section{Weighting}

I will be assigning the weights for each provision with two methods. The first is a simple additive index, sometimes referred to as a "summative" index, which assigns equal weights to each provision and then takes the sum to create the score for each city. One limitation associated with the index is that there is likely to be over and underweighting since some provisions are likely to have a stronger impact than others on the dependent variable.

To make the analysis more robust, I have also created a second index where I assigned the weights by employing a similar method used by Moe in his codification of teacher union contracts - Principal Components Analysis ("PCA"). ${ }^{192}$ PCA can be used to assign weights to provisions that correlate with the latent concept. The latent concept in this study being the dependent variable, police abuse. Thus, the PCA essentially takes a series of correlated vectors and finds combinations of these that are the most uncorrelated such that you can reduce the dimensionality of the data and find which factors or variables are most responsible for the variation in each Principal Component ("PC"). Factor loading weightings for the provisions discussed above are as follows:

192 Moe, 2009. 
Table 4 PCA | Factor Loadings

\begin{tabular}{cc}
\hline \multicolumn{1}{c}{$\begin{array}{c}\text { Principal Component Analysis } \\
\text { Factor Loadings }\end{array}$} & Factor Loading \\
\hline Cimiting Civilian Oversight & 0.27660991 \\
\hline Reducing/Preventing Civilian Oversight & 0.26730663 \\
Statutes of Limitations on Data Retention \& Use (Sustained) & 0.25150448 \\
Statutes of Limitations on Data Retention \& Use (Unsustained) & 0.07083379 \\
Restrictions on Non-Sworn Investigators & 0.39544431 \\
Requiring City to Pay for Legal Costs and Indemnification & 0.27835314 \\
Requiring City to Pay for Suspension/Fees & 0.12959478 \\
Advantages in Disciplinary Action & 0.18794792 \\
Formal Waiting Periods that Delay Investigations & 0.42233597 \\
Unfair Access to Investigative Materials (Full Access) & 0.36196724 \\
Unfair Aceess to Investigative Materials (Partial) & 0.01501378 \\
Statutes of Limitations on Filing of Complaint & 0.30029437 \\
Limiting Transparency & 0.21393239 \\
\hline
\end{tabular}


Figure 3 Principal Components Analysis

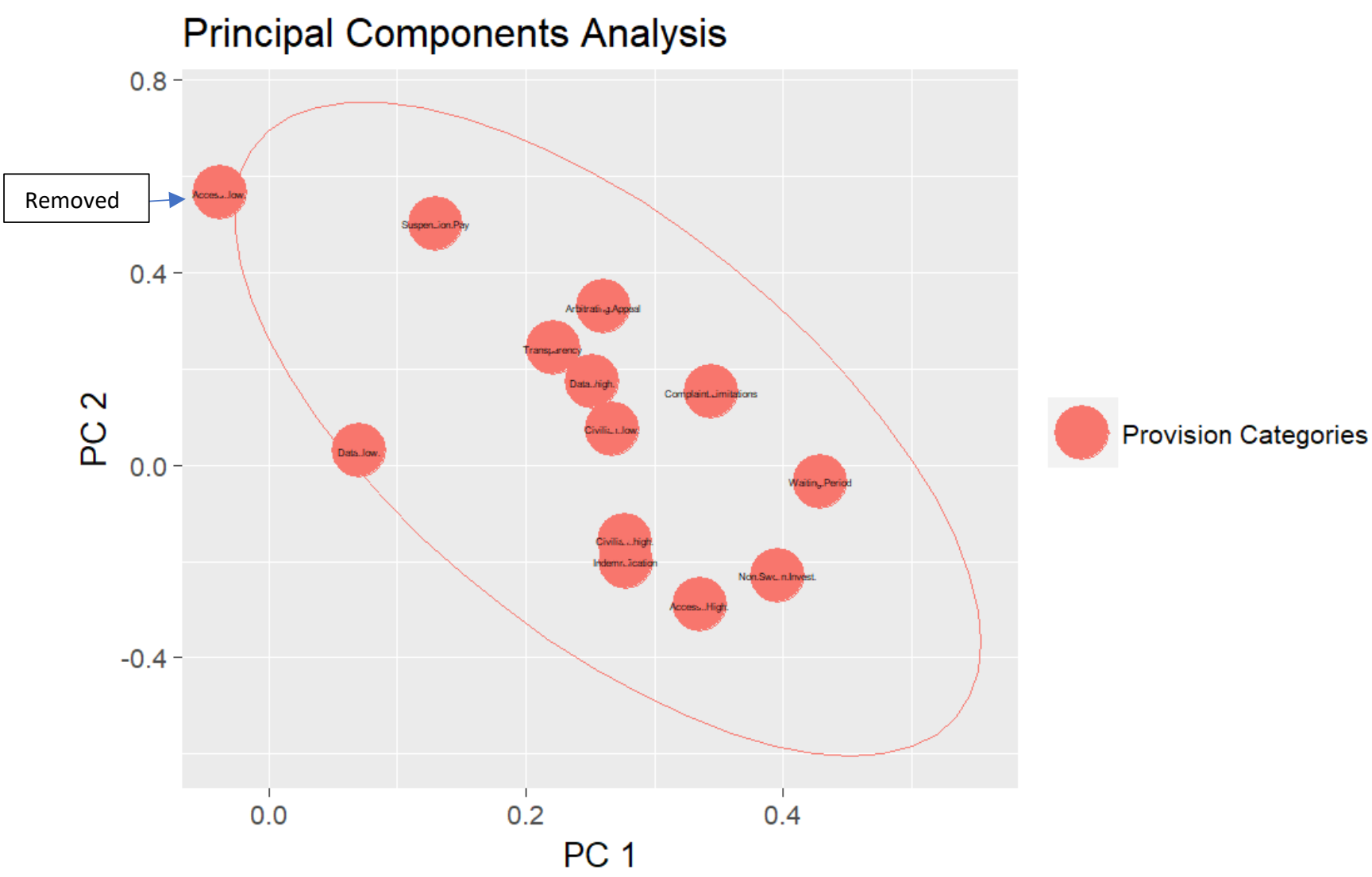

The index score will constitute the sum of the provisions which exist in the union contract. I have removed provision categories which were found to have a weight below 0.10 such as partial access to investigative materials (as noted in "Figure 3" as being outside the ring). The provisions that are most correlated with the latent concept can be seen in Table 4. While there are no studies that have employed PCA on police contract provisions, qualitative studies have placed a larger value on formal waiting periods for frustrating accountability. ${ }^{193}$ Restrictions on non-sworn investigators and access to investigative materials appear also to be indicative of provisions that are correlated with the dependent variable tested in this

${ }^{193}$ Huq and McAdams, 2016. 
study. I have used the first principal component analysis dimension because it depicts the greatest variation in the data.

There are problems associated with PCA, but they're outlined and combatted in the methodological Appendix F. For example, some argue that "Factor Analysis" would be sufficient to calculate the weightings but as argued by Velicer and Jackson, they find that there is a high degree of similarity between both PCA and Factor Analysis. Moreover, they find that employing either of the methods is unlikely to result in any empirical or substantive difference. ${ }^{194}$ Nevertheless, numerous articles have found no deductive way for determining satisfactory weights for an index, therefore, and using both the additive and the PCA factor loading weighting is used in this analysis. ${ }^{195}$ Appendix $F$ includes the police protection index scores derived by the PCA and lists each score along with the city.

\section{Limitations}

There are several limitations that apply to the construction of the police protections index. First, it fails to identify every single provision that may infringe on police accountability. However, such an exhaustive approach is extremely difficult to achieve with minimal additional benefits to analysis. Second, some of the provisions which fit the criteria for one of the above-referenced categories could be argued to be reasonable which have been highlighted in the discussion of the categories above. Most notably, including officer indemnification and having the city bear costs of misconduct which is controversial. Third, while some statelevel protections such as Law Enforcement Officer Bill of Rights (LEOBR's) have been included, there are some state-level protections which have not been included such as various legislation to protect officers. ${ }^{196}$ Fourth, it is worth noting that while these restrictive

\footnotetext{
194 Velicer and Jackson, 1990.

195 Fleischmann, et al. 1992.

196 One example of this is General Municipal 50-k in New York State which indemnifies law enforcement members from wrongdoing. There are several examples of individual states creating legislation which should be codified for future studies to better capture a comprehensive index of police protections.
} 
provisions may protect officers who commit misconduct, unions argue that these protections are necessary to protect good officers. ${ }^{197}$

Finally, this index should not be viewed as an index which is synonymous with union strength or power. This index solely measures the level of protections offered to police officers that may impede accountability. In other words, a city could score high in this index but still have a weak union which may, for example, struggle financially or organizationally. Another is that a department may have a low police protection score but have more capital and resources to focus on other efforts. It is difficult to measure union strength because of the many spheres of influence unions occupy. ${ }^{198}$ Therefore, the effect of unions as a whole cannot be quantified in one model and needs to be supplemented with qualitative evidence to better understand the different tools used by unions. ${ }^{199}$ The quantitative model intends to capture one mechanism that unions have constructed to maintain the status quo and protect their members - police protections.

The construction of this index is an original contribution of this study and a first step towards shedding light on an important and understudied area of American criminology police protections and its relationship with abuse. Moreover, the variable that captures police protections, a major union mechanism, will not only apply to one state but to America's 100 largest cities. Thus, this index will allow both academics and policy makers to better understand the role of union contract protections on different areas of policing that may need reform.

\section{Independent and Control Variables}

In addition to the primary independent variable, several other independent variables which have been established in past studies as determinants of police violence or misconduct are

\footnotetext{
197 Levinson, 2017.

198 Juris and Feuille, 1973.

199 Appendix D provides further explanation in relation to LEOBRs.
} 
being included in the model. This includes independent variables which capture racial bias and are inextricably linked to violence and abuse in policing. ${ }^{200}$ There are numerous independent variables pertaining to race included in this model to better estimate the effects of police protections on abuse. Research on police violence and accountability has established the following hypothesis as relevant: MT and Spatial hypotheses. ${ }^{201}$ Finally, the models include several control variables. Population and police force size are examples of control variables that are necessary to absorb random effects and are necessary to be controlled for in the analysis.

The controls in this model include the following:

- Violent Crime Rate (FBI Uniform Crime Reporting)

- Size of Police Force (LEMAS 2013)

- Population (US Census 2010)

Therefore, the empirical model presented in the following section is built around these variables: the dependent variable is the number of civilian deaths (as a proxy for police abuse), and the key independent variable is the index of police protections constructed by codifying union contracts. These variables aim to present empirical evidence for the following question: What is the relationship between union protections and police abuse?

\section{Empirical Model}

This model is the first attempt to quantitatively explore the relationship between union protections and police abuse. Past studies have argued that it is difficult to quantify the impact of unions and that qualitative evidence is required to better render the impact of union mechanisms. ${ }^{202}$ I acknowledge these difficulties but believe we should try to improve upon past attempts as new data and methods become available.

\footnotetext{
200 Davis, 2017.

201 US Census Bureau, “2010 Census”, 2010.

202 Walker, 2008.
} 
Numerous studies and reports have highlighted the serious problem of police departments struggling to hold their own officers accountable. ${ }^{203} \mathrm{~A}$ tabulation from the raw data of the police abuse variable used in this study finds that only 13 officers were charged with a crime (not convicted) of the 314 incidents of "Unarmed Deaths." ${ }^{204}$ As illustrated in Table 5, of the 13 officers charged with a crime for killing an unarmed civilian, only one resulted in a termination. ${ }^{205}$ While I acknowledge the merits of exploring the relationship between accountability and police protections, such a pursuit is neither suitable nor possible with the data in this study. First, there would need to be uniform data for accountability such as sustained and unsustained cases of excessive force in both internal and external oversight entities across a large set of cities. As noted earlier, some states have made individual efforts to retrieve this data. Nevertheless, data is not available across states, making it difficult to carry out a comparative study. Second, since fellow officers are likely to have their own biases, there is an issue of bias reporting by fellow officers which can corrupt the information in a report. Third, it is important to remember that some incidents of misconduct will never be reported because of fear of retaliation for filing a complaint. Finally, there are a string of unobservable variables that are likely to better explain the lack of accountability, such as the prosecutor's decision not to prosecute or their inability to sufficiently provide the jury with a fair representation of the case. ${ }^{206}$ Both internal and external (civilian oversight) investigation data needs to be retrieved to conduct a thorough study which can explain more about the variables involved with accountability. Police deaths of civilians, standing on its own, cannot be used as a proxy for accountability or lack thereof.

\footnotetext{
203 Rushin, 2017; Keenan and Walker, 2005; Huq and McAdams, 2016.

204 Campaign Zero, "Mapping Police Violence Database”, 2016.

205 These 129 cases render that only $10.1 \%$ of cases that have been reviewed (more than half of the Unarmed Deaths) between 2013-2016 of unarmed deaths resulted in some type of charge. Majority of cases that are likely to be taken seriously tend to lead to the department acting swiftly to remove or take action on the officer. Meanwhile, the remainder of the cases are under review or pending investigation which speaks to the lack of urgency or seriousness of prosecution. 206 Wright, 2017.
} 
Table 5 Outcome of "Unarmed Deaths"

\begin{tabular}{ccccc}
\hline \multicolumn{5}{c}{ Outcome of Unarmed Deaths (Reviewed) } \\
\hline $\begin{array}{c}\text { Charged - } \\
\text { No Conviction }\end{array}$ & Justified & $\begin{array}{c}\text { Not Justified } \\
\text { (Fired) }\end{array}$ & $\begin{array}{c}\text { No Known } \\
\text { Charges }\end{array}$ & Accidental/Excusable \\
13 & 22 & 1 & 91 & 3 \\
\hline
\end{tabular}

This paper builds upon the scarce literature on police unions, some of which that argues union contract protections create or continues a so-called "culture of impunity." ${ }^{207}$ This concept holds that the lack of a deterrent effect or the lack of a consequence for one's actions creates an atmosphere where more misconduct occurs. Thus, the police protections index, which is composed of provisions that protect officers who commit misconduct, create a weaker deterrent effect, and reduce accountability, is best suited to test this theory.

This study holds as a central hypothesis that there is a positive and significant relationship between police protections and police abuse. I do not argue that police protections are the primary reason for abuse. Instead, this model will further investigate the ways in which police unionism perpetuates and insulates abuse. I hypothesize that reducing deterrence effects could create environments where officers are more likely to commit actions of misconduct because there will be consequences or repercussions. It is also plausible that officers may not be cognizant of the individual provisions and protections, rather, it may be reflected in the culture in which they have adapted and learned from their fellow officers. In other words, these protections individually may not be considered and could be viewed as a reflection of the police culture.

That being said, I also consider the role of other relevant and established determinants of police abuse. Thus, it is imperative to include race-relevant variables with the interconnectedness of race and policing in America. In terms of race, research finds the Minority Threat and Spatial hypothesis as relevant.

${ }^{207}$ Refer to Literature Review (Chapter 2). 
To summarize, the analytic framework in the chapter will focus on exploring whether police protections are a determinant of police abuse, proxied by police related deaths of unarmed civilians or deaths of civilians who were not wielding a deadly weapon, in America's largest 100 cities. $^{208}$

The model is as follows:

$$
\begin{gathered}
\text { PoliceAbuse } \left._{i t}\right)=\alpha_{i}+\beta_{1}\left(\text { PoliceProtections }_{i t}\right)+\beta_{2}\left(\mathrm{MT}_{\text {Minority Threat Black }}\right)_{\text {it }}+ \\
\beta_{3}\left(\mathrm{MT}_{\text {Minority Threat Hispanic }}\right)_{\text {it }}+ \\
\beta_{4}\left(\mathrm{PL}_{\text {Black Spatial }}\right)_{\text {it }}+\beta_{5}\left(\mathrm{PL}_{\text {Hispanic Spatial }}\right)_{\text {it }}+ \\
\mathrm{X}_{\mathrm{it}}+\varepsilon_{\mathrm{it}}
\end{gathered}
$$

Subscript $i$ represents the police department, while, $t$ denotes the regional fixed effect. B denotes the regression coefficients for the independent variables. E represents the error term. X represents the control variables, which include population, violent crime rate, and the size of police department. This model employs ordinary least squares (OLS) with regional fixed effects and clusters the standard errors by region as well in order to estimate the model coefficients. ${ }^{209}$ The analysis takes place at the city-level and uses the primary law enforcement agency in each city as the unit of analysis. Since the study looks across the US, regional fixed effects have been included to account for historical legacies that vary between regions, such as race relations. While state fixed effects were considered as a substitute for regional, the data would have been skewed since there are only 100 observations in this study. ${ }^{210}$ Moreover, existing criminology studies have found regional fixed effects to be relevant and sufficient. ${ }^{211}$

\footnotetext{
208 Surowiecki, 2016; Walker and Keenan, 2005; Magenau and Hunt, 1996.

${ }^{209}$ White, 1980. Justification for OLS with Robust standard errors. This was also included in the model

210 Some states have 1 observation, whereas, other states like California which has 17 observations which is counterintuitive.

211 Smith and Holmes, 2014.
} 


\section{CHAPTER 5}

\section{POLICE PROTECTIONS \& POLICE ABUSE: FINDINGS}

The following section will analyze the results of the proposed model in the previous section which explores the relationship between the originally constructed variable of police protections and the dependent variable, police abuse.

\section{Findings}

Descriptive analysis of the data is presented in Table 6. Appendix $H$ presents a table with key variables investigated in this study alongside each observation. To reiterate, OLS with regional fixed effects and robust standard errors clustered by region is being employed to run the models. Other methods such as a Negative Binomial regression were considered but were ultimately not employed that they were not necessary. ${ }^{212}$ Appendix I provides reasons for the method chosen.

${ }^{212}$ Nonetheless, they were run in Appendix I and were similarly significant. Appendix $J$ includes additional tests including alternative variables. 
Table 6 Predicted Signs \& Descriptive Statistics

\begin{tabular}{|c|c|c|c|c|c|}
\hline \multicolumn{6}{|c|}{ Predicted Signs \& Descriptive Statistics } \\
\hline VARIABLE & $\begin{array}{l}\text { Predicted } \\
\text { Sign }\end{array}$ & Mean & $\overline{\mathrm{SD}}$ & Min & Max \\
\hline \multicolumn{6}{|l|}{ Dependent Variable(s) } \\
\hline Number of Police "Abuse" Killings 213 & & 3.14 & 4.08 & 0 & 29 \\
\hline Number of Police Killings of Black Civilians & & 5.93 & 8.31 & 0 & 51 \\
\hline Number of Police Killings & & 15.08 & 16.02 & 0 & 100 \\
\hline \multicolumn{6}{|l|}{ Independent Variable(s) } \\
\hline \multicolumn{6}{|l|}{ Union Contract Index of Police Protections } \\
\hline Police Protections (Additive) & + & 3.53 & 2.52 & 0.00 & 9.00 \\
\hline Police Protections (PCA) & + & .89 & .75 & 0.00 & 2.71 \\
\hline \multicolumn{6}{|l|}{ Minority Threat Variables } \\
\hline Percent Black & + & 20.60 & 18.16 & .20 & 82.18 \\
\hline Percent Hispanic & + & 23.53 & 19.78 & 2.28 & 95.620 \\
\hline \multicolumn{6}{|l|}{ Place Variables } \\
\hline Black Spatial & + & 47.77 & 16.06 & 17.24 & 82.48 \\
\hline Hispanic Spatial & + & 41.90 & 11.95 & 14.14 & 66.87 \\
\hline \multicolumn{6}{|l|}{ Control Variable(s) } \\
\hline Population & + & 635,098 & 958,448 & 210,347 & $8,473,938$ \\
\hline Violent Crime (per 100,000/ residents) & + & 7.07 & 3.97 & .49 & 19.87 \\
\hline $\begin{array}{l}\text { Police Department (\# of full-time } \\
\text { sworn officers) }\end{array}$ & + & 1,640 & 3,741 & 171 & 34,454 \\
\hline Observations - 100 & & & & & \\
\hline
\end{tabular}

The police protection additive index has a mean of 3.53 , a standard deviation of 2.52 and includes a range from 0 to 9 . The police protections PCA index has a mean .89, a standard deviation of .75 and includes a range from 0 to 2.71. Existing literature on public sector unions has established the link between contract strength and union membership/ population. ${ }^{214}$ As illustrated in "Figure 4", population on its own is not a determinant for the level of police protections. One may also suspect that police protections are more likely to be found in cities that exhibit higher crime rates, or those which are considered to be more dangerous places where officers are more likely make mistakes. This may be because police officers are worried more about the consequences of their actions in cities where they know they may confront conflict more often. Interestingly, as shown in "Figure 4", cities with higher crime rates seem to have no relationship with cities that contain greater levels of

\footnotetext{
${ }^{213}$ The filtering steps which were taken to create this variable are in Appendix $C$.
} ${ }^{214}$ Freeman and Han, 2015. 
protections. There is a $\mathrm{p}$ value of .318 and an adjusted R-Squared of $8.375 \mathrm{e}-05$ which makes it apparent that there is no relationship between the two variables in question.

Figure 4 Scatterplots | Police Protections by Crime Rate and Population
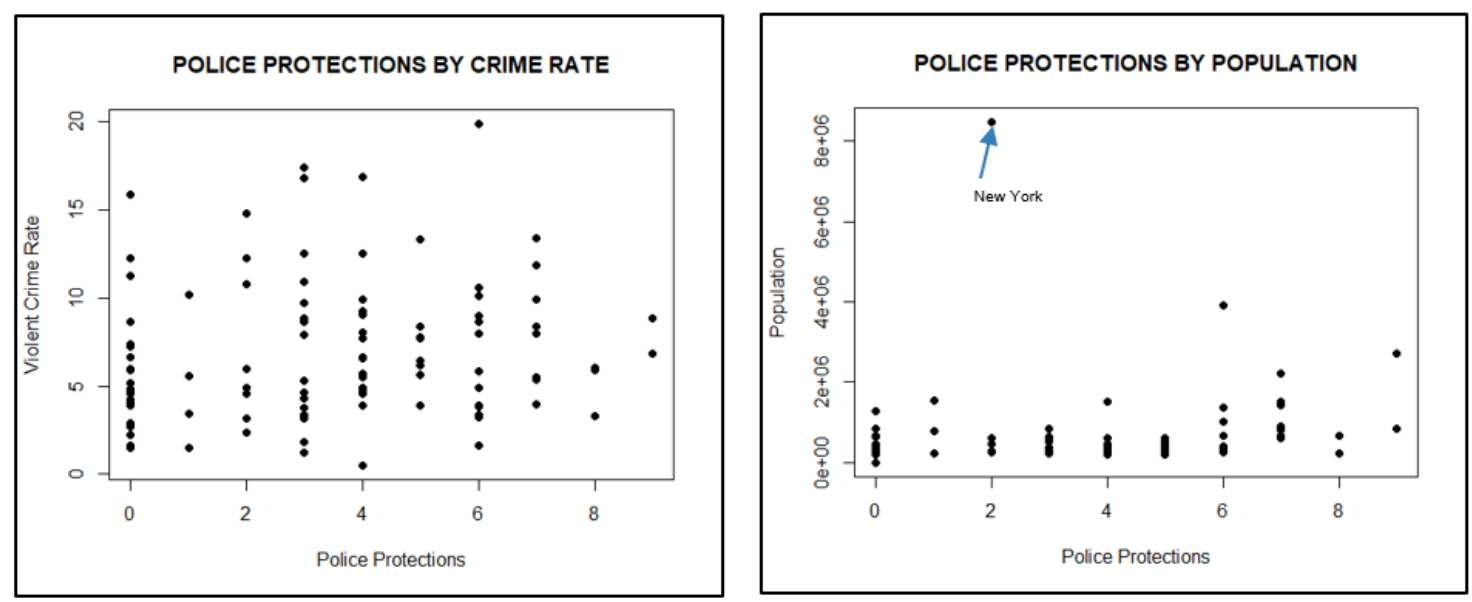

Analysis

Figure 5 Alluvial Diagram | Police Protections and Levels of Abuse

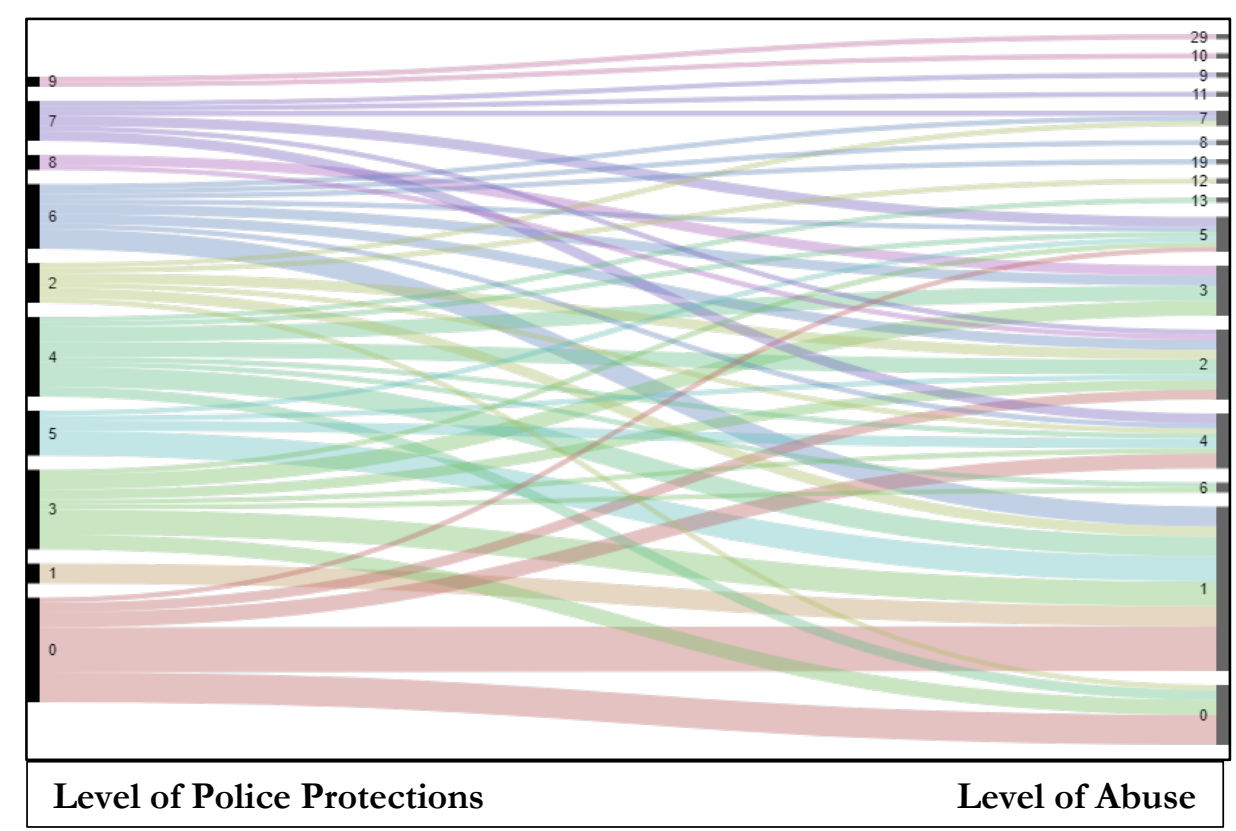

Finally, turning to the focus of this study: the relationship between police protections and police abuse (See "Figure 5"). As rendered in "Figure 5", cities with a higher police protection score are more likely to have more abuse. "Figure 6" illustrates that the relationship between the two variables is consistent with the central hypothesis of this study. Moreover, the second plot with the trend lines represent the different lines for each region: North, South, 
Northwest, Southwest. ${ }^{215}$ Nevertheless, it is important to note that simple two-dimensional relationships are misleading because they do not account for crucial controls such as population, crime rate and size of police department. Thus, the inclusion of control variables may change the findings, yet, are necessary in constructing a model that accounts for other explanatory dimensions.

Table 7 Regression Tables | Police Protections (Additive Index) and Police Abuse

Police Protections and Abuse (Additive Index)

\begin{tabular}{|c|c|c|c|c|}
\hline & \multicolumn{4}{|c|}{ Dependent variable: } \\
\hline & \multicolumn{2}{|c|}{ POLICE ABUSE } & \multicolumn{2}{|c|}{ UNARMED DEATHS } \\
\hline & (1) & (2) & (3) & (4) \\
\hline POLICE PROTECTIONS & $\begin{array}{l}0.5153^{* *} \\
(0.2330)\end{array}$ & $\begin{array}{l}0.5337^{* *} \\
(0.2334)\end{array}$ & $\begin{array}{l}0.3515^{* *} \\
(0.1599)\end{array}$ & $\begin{array}{c}0.3668^{* * * *} \\
(0.1359)\end{array}$ \\
\hline POPULATION & $\begin{array}{c}0.000003 \\
(0.000003)\end{array}$ & $\begin{array}{c}0.000003 \\
(0.000003)\end{array}$ & $\begin{array}{l}0.000004^{*} \\
(0.000002)\end{array}$ & $\begin{array}{c}0.000003^{* * *} \\
(0.000001)\end{array}$ \\
\hline VIOLENT CRIME RATE & $\begin{array}{c}0.1229 \\
(0.0778)\end{array}$ & $\begin{array}{l}-0.0590 \\
(0.1285)\end{array}$ & $\begin{array}{c}0.1220 \\
(0.0770)\end{array}$ & $\begin{array}{l}-0.0376 \\
(0.0880)\end{array}$ \\
\hline SIZE OF DEPARTMENT & $\begin{array}{l}-0.0003 \\
(0.0007)\end{array}$ & $\begin{array}{l}-0.0003 \\
(0.0006)\end{array}$ & $\begin{array}{l}-0.0004 \\
(0.0004)\end{array}$ & $\begin{array}{l}-0.0004^{*} \\
(0.0002)\end{array}$ \\
\hline BLACK_MT & & $\begin{array}{l}0.0271^{* *} \\
(0.0107)\end{array}$ & & $\begin{array}{l}0.0267^{*} \\
(0.0135)\end{array}$ \\
\hline HISPANIC_MT & & $\begin{array}{c}0.0306 \\
(0.0192)\end{array}$ & & $\begin{array}{l}0.0273^{* *} \\
(0.0108)\end{array}$ \\
\hline BLACK SPATIAL & & $\begin{array}{l}0.0486^{* *} \\
(0.0239)\end{array}$ & & $\begin{array}{l}0.0429^{*} \\
(0.0248)\end{array}$ \\
\hline HISPANIC SPATIAL & & $\begin{array}{c}0.0159 \\
(0.0201)\end{array}$ & & $\begin{array}{c}0.0092 \\
(0.0112)\end{array}$ \\
\hline Observations & 100 & 100 & 100 & 100 \\
\hline $\mathrm{R}^{2}$ & 0.5098 & 0.5479 & 0.5771 & 0.6194 \\
\hline Adjusted $\mathrm{R}^{2}$ & 0.4725 & 0.4914 & 0.5449 & 0.5718 \\
\hline Residual Std. Error & $2.9596(\mathrm{df}=92$ & $.9061(\mathrm{df}=88$ & $2.2701(\mathrm{df}=9$ & $2.2019(\mathrm{df}=88)$ \\
\hline
\end{tabular}

215 Since I am controlling for regional fixed effects, it is best to illustrate the trend lines for each of the US regions. 
Figure 6 Scatterplot and Scatterplot with Trend Line | Police Protections (Additive) and Police Abuse
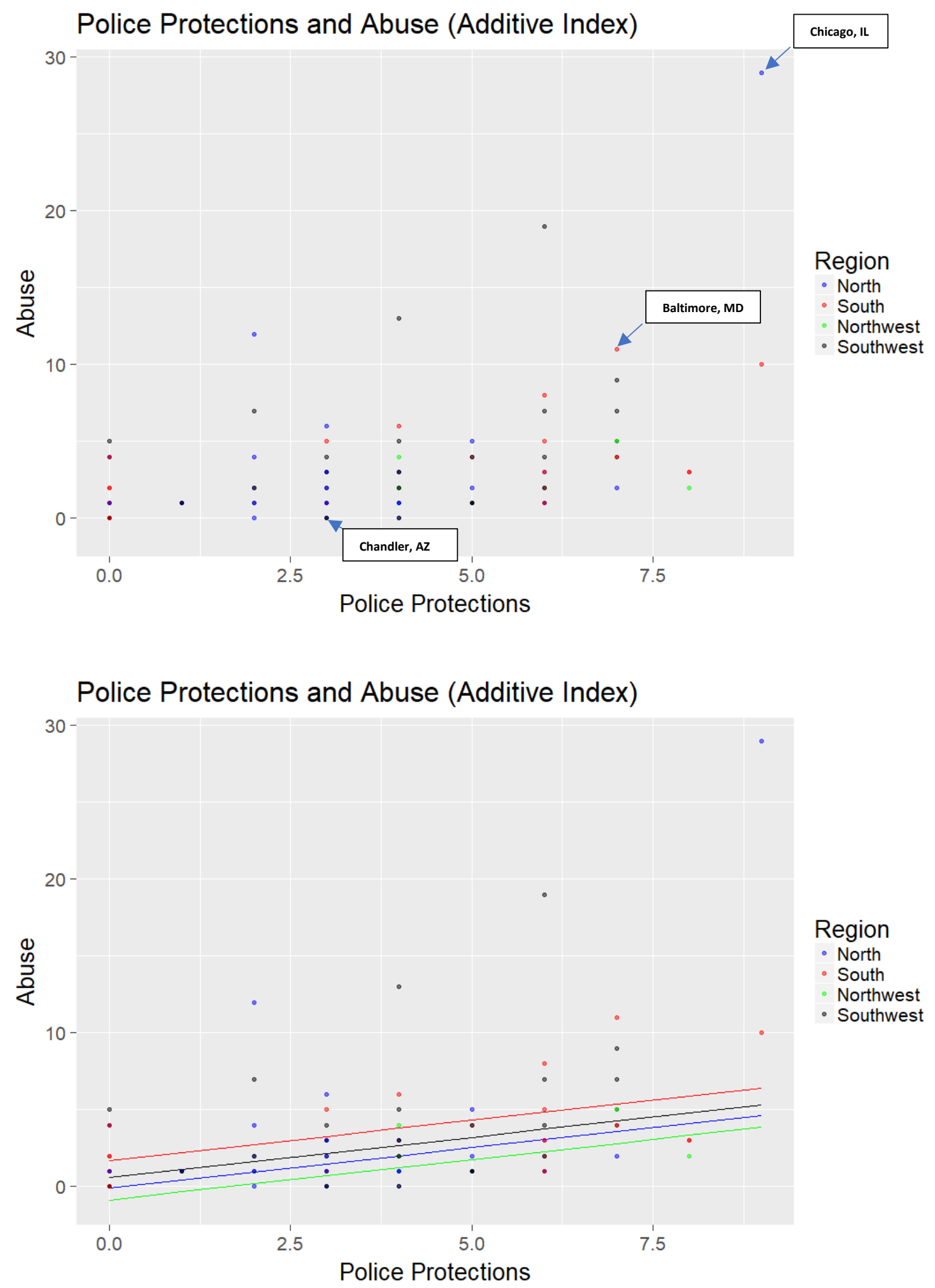
The results from the multi-variate models can be found in "Table 7". In Column 1, I start with the simple analysis between police protections and police abuse which includes basic control variables. As predicted before, there is a significant and positive relationship between police protections and population even when controlling for the effects of other variables. Chicago, which is indicated in "Figure 4", represents the extreme case scoring a police protection score of 9 and has the greatest level of police abuse. In other words, this model states that a one unit increase in the police protection index has a .51 increase in police abuse, which is significant.

Column 2 includes the Minority Threat (MT) and Spatial variables which stipulate that cities with larger populations of Black/Hispanic Groups and higher levels of segregation are likely to exhibit more instances of police violence and abuse. ${ }^{216}$ This model confirms that the Black MT variable is relevant in predicting police abuse. ${ }^{217}$ The Spatial hypothesis uses the dissimilarity index to proxy for segregation and argues that the greater the level of segregation for Black/Hispanic groups, the more likely there will be police use of excessive force in those communities. The results find protections to continue to be significant (.53); meanwhile, the Black Spatial variable shows strong associations with more police abuse. Again, police protections continue to be significant and seem to have a slightly larger effect on the inclusion of the MT and Spatial co-variates. Baltimore, Maryland constitutes a clear example of a city which fits this theory (see "Figure 6"). It has a police protection score of 7 (additive index) and a high level of police abuse (11 civilian "abuse" deaths) for a city where $63 \%$ of its population is Black (4\% is Hispanic). Additionally, Baltimore has a large dissimilarity index score of $68 \%$ (Black-White). In contrast, we can examine a city like Chandler, Arizona, which represents the other side of the spectrum. Chandler has a police protection score of 3

216 Smith and Holmes, 2014.

217 This is not a new finding, nor does it dispute other findings. Additionally, this should not be confused as meaning that Black persons are more likely to be killed, nor should it be taken that Black persons are less likely to be killed - this model simply conveys the notion that abuse is more likely in cities that have larger percentages of Black and Hispanic populations. 
and the lowest level of abuse (0 "abuse" deaths). Moreover, giving support to both the Spatial and Minority Threat hypotheses, Chandler has a dissimilarity index score of 17\% (BlackWhite) and 21\% (Hispanic-White) with a Black population of $4 \%$ and a Hispanic population of $22 \%$.

Column 3 and 4 employs unarmed deaths of civilians as the dependent variable to further illustrate that the police abuse variable is sufficient for testing the theory but to also demonstrate that it is significant with a less disputable form of "abuse." Police protections continue to be significant with a slightly smaller coefficient. However, one difference is that the Hispanic MT variable in column 4 is significant in contrast to the models employing police abuse as the dependent variable. Nevertheless, these models are generally in line with existing findings looking at police excessive use of force and accountability. ${ }^{218}$

One thing worth noting is that some of the observations are heavily skewing the study, most notably, New York, as illustrated in "Figure 7" in a "Residuals v. Leverage" plot. There can be several reasons for why New York is skewing the data which can range from rather obvious reasons, like its size, or other reasons such as crime rates in proportion to other salient variables. Additionally, as noted earlier, New York may have a string of state level protections which were not included in the study and may explain the outlier. Nevertheless, as illustrated in “Table 7", the models are all still significant while including New York. ${ }^{219}$ Thus, a more in-depth study should further explore why New York is an outlier.

218 Smith and Holmes, 2014

${ }^{219}$ New York may have a string of police protection housed within state legislation which needs to be further explore. 
Figure 7 Residuals v. Leverage | New York

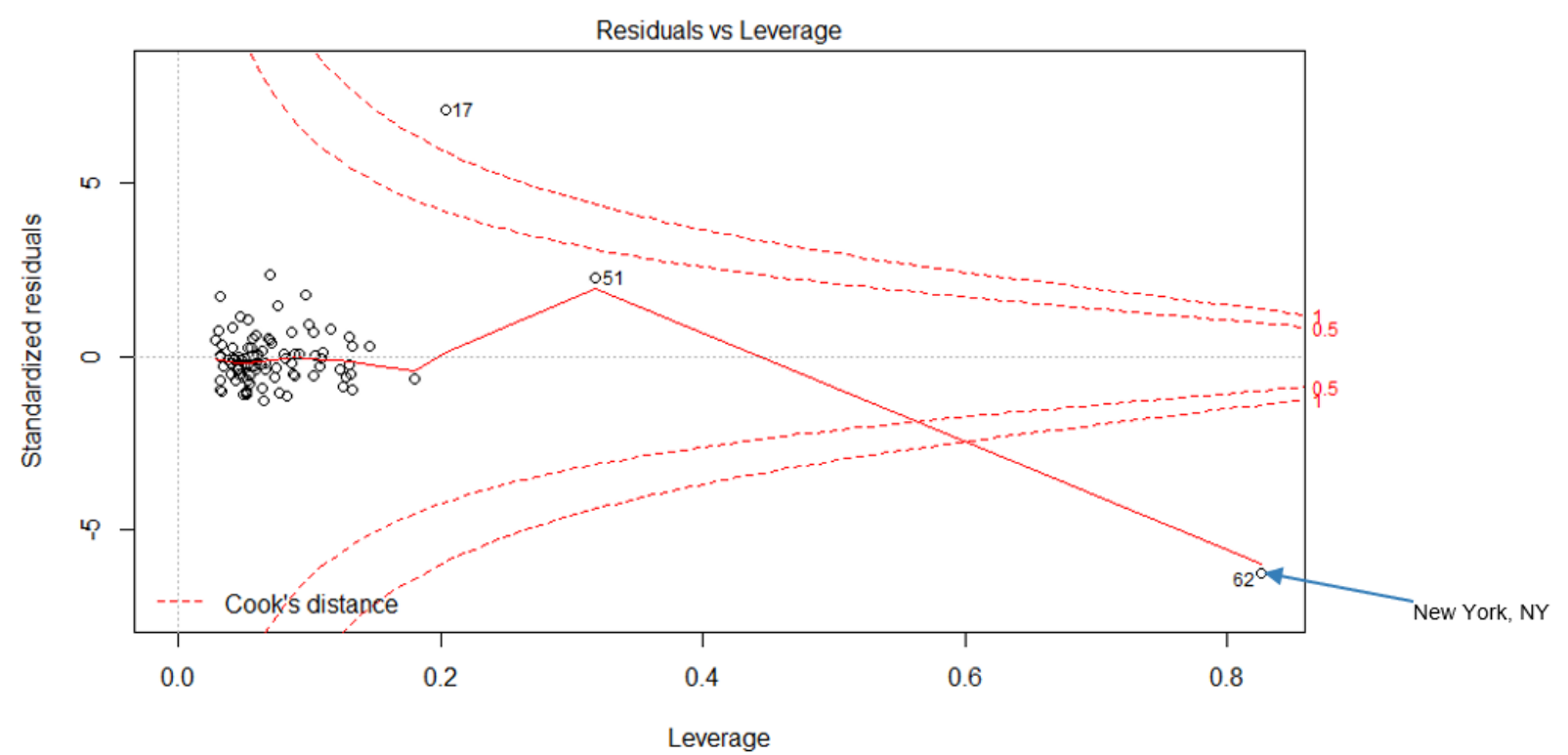

"Table 8" presents the same models but employs the PCA factor loading index, as opposed to the previous models which employed the simple additive index. As stated earlier, the PCA weightings assign weights to the provisions based on their correlation to the latent concept being police abuse in this case. Moreover, the PCA analysis provides a more credible and rigorous method to calculating the police protection scores for each city. Thus, this model is only to illustrate that both methods used to create the police protections index should be sufficient in testing the hypotheses. As illustrated in "Table 8", the models yield stronger coefficients because the scale of the index is shorter. In column 1, police protections are significant and positively correlated with police abuse (1.67). In other words, 1.7 deaths per each unit increase on the police protection index. This significant finding is worth revisiting in future studies employing better proxies for police abuse, as noted earlier, excessive use of force data is best suited to test this theory. Similarly, the Black MT and Black Spatial are both significant. In contrast to the additive index models, the Hispanic MT variable is significant when controlling for all variables. Nevertheless, the key variable in question being police protections remains significant across each model which serves as a justification for using 
either an additive or PCA index for the subsequent models. "Figure 8" includes a scatterplot and trend line.

Table 8 Regression Table | Police Protections and Police Abuse (PCA INDEX)

Police Protections and Abuse (PCA Index)

\begin{tabular}{|c|c|c|c|c|}
\hline & \multicolumn{4}{|c|}{ Dependent variable: } \\
\hline & \multicolumn{4}{|c|}{ POLICE ABUSE } \\
\hline & (1) & (2) & (3) & (4) \\
\hline POLICE PROTECTIONS & $\begin{array}{l}1.6642^{*} \\
(0.9386)\end{array}$ & $\begin{array}{l}1.6851^{*} \\
(0.9145)\end{array}$ & $\begin{array}{l}1.6493^{*} \\
(0.9740)\end{array}$ & $\begin{array}{l}1.6239^{*} \\
(0.9909)\end{array}$ \\
\hline POPULATION & $\begin{array}{c}0.000003 \\
(0.000003)\end{array}$ & $\begin{array}{c}0.000004 \\
(0.000003)\end{array}$ & $\begin{array}{c}0.000003 \\
(0.000003)\end{array}$ & $\begin{array}{c}0.000003 \\
(0.000003)\end{array}$ \\
\hline VIOLENT CRIME RATE & $\begin{array}{l}0.1338^{*} \\
(0.0730)\end{array}$ & $\begin{array}{c}0.0690 \\
(0.0623)\end{array}$ & $\begin{array}{c}0.0146 \\
(0.1180)\end{array}$ & $\begin{array}{l}-0.0166 \\
(0.1184)\end{array}$ \\
\hline SIZE OF DEPARTMENT & $\begin{array}{l}-0.0003 \\
(0.0007)\end{array}$ & $\begin{array}{l}-0.0004 \\
(0.0007)\end{array}$ & $\begin{array}{l}-0.0002 \\
(0.0007)\end{array}$ & $\begin{array}{l}-0.0003 \\
(0.0007)\end{array}$ \\
\hline BLACK_MT & & $\begin{array}{c}0.0295^{* * *} \\
(0.0094)\end{array}$ & & $\begin{array}{l}0.0191^{*} \\
(0.0104)\end{array}$ \\
\hline HISPANIC_MT & & $\begin{array}{c}0.0277 \\
(0.0175)\end{array}$ & & $\begin{array}{l}0.0275^{*} \\
(0.0155)\end{array}$ \\
\hline BLACK SPATIAL & & & $\begin{array}{l}0.0454^{*} \\
(0.0237)\end{array}$ & $\begin{array}{l}0.0458^{*} \\
(0.0266)\end{array}$ \\
\hline HISPANIC SPATIAL & & & $\begin{array}{c}0.0189 \\
(0.0270)\end{array}$ & $\begin{array}{c}0.0132 \\
(0.0262)\end{array}$ \\
\hline Observations & 100 & 100 & 100 & 100 \\
\hline $\mathrm{R}^{2}$ & 0.5020 & 0.5159 & 0.5210 & 0.5321 \\
\hline Adjusted $\mathrm{R}^{2}$ & 0.4641 & 0.4674 & 0.4731 & 0.4737 \\
\hline Residual Std. Error & $2.9831(\mathrm{df}=92)$ & $2.9739(\mathrm{df}=90$ & $2.9581(\mathrm{df}=90)$ & $2.9565(\mathrm{df}=88)$ \\
\hline
\end{tabular}


Figure 8 Scatterplot and Scatterplot with Trend Line | Police Protections (PCA) and Police Abuse
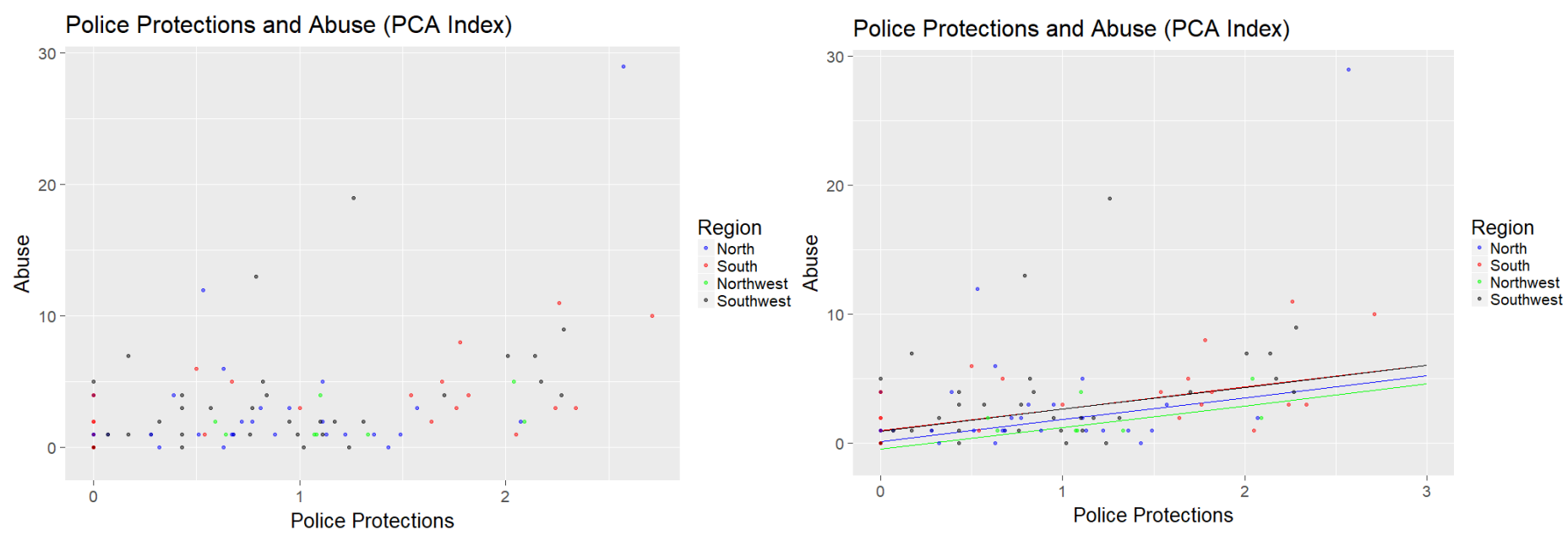

In "Table 9", I have included all police killings observed in the "Mapping Police Violence" dataset for the 100 cities in question. This is intended to test whether the differences in the previous models are associated with police abuse or just an unmeasured feature of civilian deaths at the hands of police. Thus, I have replaced the dependent variable from abuse to all police killings. This purports the notion that protections create abuse, in contrast to the idea that protections are found in cities with more police violence in general. As illustrated across all models in “Table 9", police protections remain insignificant across each model despite controlling for different variables. However, race-related variables continue to remain significant with a slightly larger effect than the previous models that determine police abuse. This test provides further evidence for the theory that police protections in union contracts are a strong predictor of abuse. "Figure 9" represents a scatterplot of the two dimensions being measured. ${ }^{220}$

220 Appendix $J$ includes regression involving additional institutional variables such as use of force policies. 
Table 9 Regression Table | Police Protections and Police Killings of Civilians

Police Protections and All Police Killings

\begin{tabular}{|c|c|c|c|c|}
\hline & \multicolumn{4}{|c|}{ Dependent variable: } \\
\hline & \multicolumn{4}{|c|}{ POLICE KILLINGS } \\
\hline & (1) & (2) & (3) & (4) \\
\hline POLICE PROTECTIONS & $\begin{array}{c}2.6514 \\
(2.9066)\end{array}$ & $\begin{array}{c}2.7776 \\
(3.0021)\end{array}$ & $\begin{array}{c}2.6002 \\
(2.8726)\end{array}$ & $\begin{array}{c}2.6443 \\
(3.1202)\end{array}$ \\
\hline POPULATION & $\begin{array}{c}0.00003^{* * *} \\
(0.00001)\end{array}$ & $\begin{array}{c}0.00003^{* * *} \\
(0.00001)\end{array}$ & $\begin{array}{c}0.00003^{* * *} \\
(0.00001)\end{array}$ & $\begin{array}{c}0.00003^{* * *} \\
(0.00001)\end{array}$ \\
\hline VIOLENT CRIME RATE & $\begin{array}{c}0.6986^{* * *} \\
(0.1707)\end{array}$ & $\begin{array}{c}0.5625^{* * *} \\
(0.1803)\end{array}$ & $\begin{array}{c}0.3901 \\
(0.2608)\end{array}$ & $\begin{array}{c}0.3316 \\
(0.2809)\end{array}$ \\
\hline SIZE OF DEPARTMENT & $\begin{array}{c}-0.0058^{* * *} \\
(0.0020)\end{array}$ & $\begin{array}{c}-0.0060^{* * *} \\
(0.0019)\end{array}$ & $\begin{array}{c}-0.0056^{* * *} \\
(0.0018)\end{array}$ & $\begin{array}{c}-0.0057^{* * *} \\
(0.0018)\end{array}$ \\
\hline BLACK_MT & & $\begin{array}{c}0.0575 \\
(0.0386)\end{array}$ & & $\begin{array}{c}0.0306 \\
(0.0553)\end{array}$ \\
\hline HISPANIC_MT & & $\begin{array}{c}0.0204 \\
(0.0271)\end{array}$ & & $\begin{array}{c}0.0193 \\
(0.0424)\end{array}$ \\
\hline BLACK SPATIAL & & & $\begin{array}{l}0.1204^{* *} \\
(0.0556)\end{array}$ & $\begin{array}{c}0.1166 \\
(0.0739)\end{array}$ \\
\hline HISPANIC SPATIAL & & & $\begin{array}{c}0.0453 \\
(0.0343)\end{array}$ & $\begin{array}{c}0.0426 \\
(0.0447)\end{array}$ \\
\hline Observations & 100 & 100 & 100 & 100 \\
\hline $\mathrm{R}^{2}$ & 0.7026 & 0.7041 & 0.7109 & 0.7115 \\
\hline Adjusted $\mathrm{R}^{2}$ & 0.6800 & 0.6745 & 0.6820 & 0.6755 \\
\hline Residual Std. Error & $9.0630(\mathrm{df}=9$ & $1405(\mathrm{df}=90$ & $0348(\mathrm{df}=9$ & $.1275(\mathrm{df}=88)$ \\
\hline
\end{tabular}

Figure 9 Scatterplot | Police Protections and Police Killings

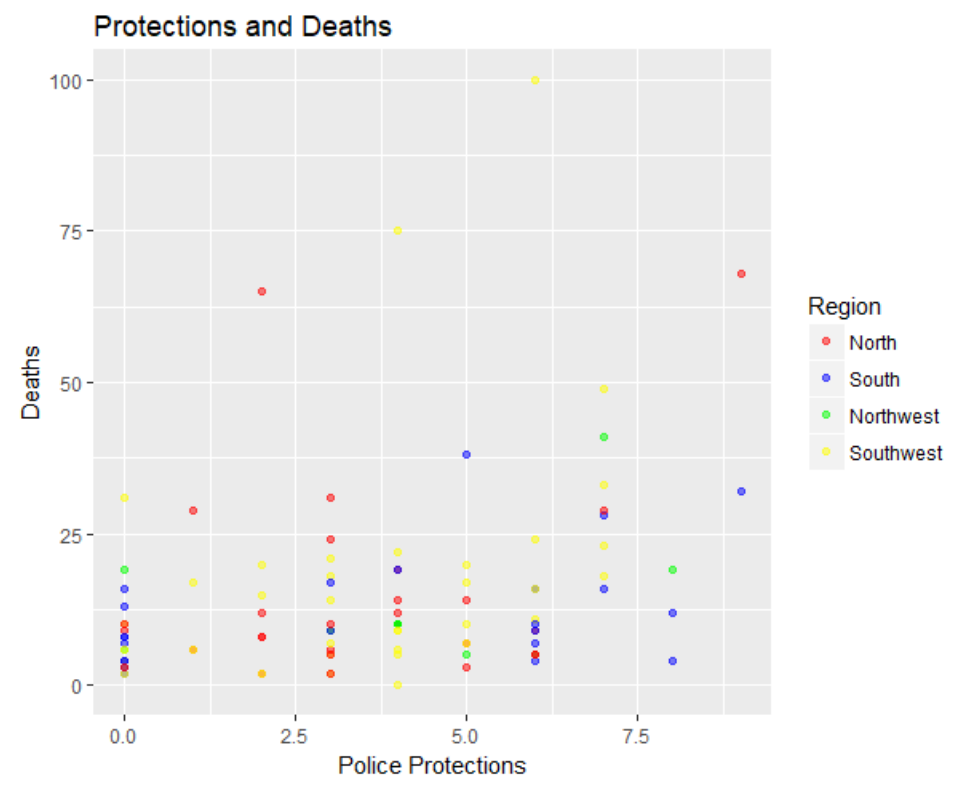




\section{Endogeneity}

A common problem encountered in studies of this nature is endogeneity bias. In this case, the question posed is whether abuse creates more police protections. This is a valid concern, yet it is unlikely due to several reasons. Prior to discussing the problems with this theory, it is worth discussing the potential mechanism that supports the view of this bias.

Law enforcement members and unions have a vested interest in protecting their officers. Police officer associations or groups are likely to safeguard themselves from discipline or accountability in areas where they realize they are more at risk of misconduct investigations (or where there may be rampant abuse). This would not be surprising, since it is the role of unions to represent their members' interests, whether or not their interests are reflective of the interests of the community in which they serve. Thus, in cities where there is less abuse, there may be less of a focus to create protections to shield officers, and the focus can shift to other pertinent issues such as increasing pay or obtaining better fringe benefits.

First, on a technical point, the alternate theory could not be supported by the data used in this study nor is the data available. The data from this study looks at civilian deaths from 2013-2016. This does not mean that police killings of unarmed civilians did not exist prior to 2013 . While we do not know the magnitude of police abuse in the past, we are aware that police union contracts only came into existence in the latter half of the twentieth century during the "War on Drugs". ${ }^{221}$ Thus, it is difficult to argue that the police protections caused abuse in the past since there was a time when union protections did not exist. Unfortunately, accurate uniform numbers across cities are not available for the period needed to test this alternative theory at the present time. In order to establish this, we would need to obtain data from the year prior, and following the implementation of union contracts, and employ

\footnotetext{
221 Juris and Feuille. 1973.
} 
a difference-in-difference approach to render how abuse shaped protections. ${ }^{222}$ Moreover, it would require the first version of the original contracts, which vary greatly temporally and are beyond the scope of this study. It is worth noting that the most recent study by Dharmapala, et al. looked specifically at Florida departments before and after receiving bargaining rights and found the difference-in-difference approach as helpful in confirming that bargaining power did increase misconduct. ${ }^{223}$ Their study only focuses one state, but further supports the theory and mechanism in this model.

Second, I recognize and do not dispute the claim that abuse, initially, may have shaped the protections when contract protections first were implemented in the latter half of the twentieth century. This is a fair criticism, but neither this paper nor this model is disputing that abuse may have shaped original protections. Moreover, the independent variable of police protections in this study does not change in the period examined in this thesis, albeit within a small temporal scope. Protection provisions have been found to be fairly static, and the removal or addition of provisions has been deemed a "largely rare occurrence." 224 Therefore, the data being used in this model writes another story which does not dispute the origins of the protections. Rather, it explores how these static protections have created an insulator-like effect in the present - reducing deterrence for officers by weakening accountability systems and creating an atmosphere which continues abuse.

Another potential endogeneity problem involves other factors not controlled for which are causally linked to the key variables and are excluded from the model. For example, there are state-level police protections which may provide substantial protections that are not included in union contracts. In this type of situation, a police department may be rendered as having

\footnotetext{
222 Some original union contracts may potentially be obtained but it would be a timely process. Moreover, should I have obtained the original contracts, data regarding police related deaths of unarmed civilians was not uniformly documented during the period in which many cities started drafting and implementing union contracts. Additionally, the same period where large cities started to implement police labour contracts also falls under the same period of the war on drugs where there is a serious lack of data, and where there is data, it has been argued to be unreliable. 223 Dharmapala, et al., 2017.

224 Walker, 2008; Keenan and Walker, 2008; Huq and McAdams, 2016.
} 
weak police protections according to the index in this paper, yet, in reality, officers are offered strong protections from the state. State-level protections could be viewed as an extension of union protections since many unions are lobbying at the state-level for certain protections. ${ }^{225}$

Finally, there are a number of other variables that are more likely to have had an impact on creating policing protections, such as the political ideology of the city and state, which can assist or restrain the ability of the union to create protections. This theory will be tested in the subsequent chapter.

A problem beyond endogeneity bias surrounds the temporal scope of the data being employed. The years selected could potentially be outliers where there may be more or less abuse than the average year. In other words, the average year in the period of analysis may not be the average year for the city. Finally, there remains the problem of the small range with the dependent variable of police abuse which is a valid concern. Nevertheless, this concern was addressed earlier and involves problems that revolve around issues related to there being a lack of data or access to data best suited to capture the effect of police protections. Moreover, while excessive use of force data has yet to be available on the national scale, efforts are underway to collect this data on the state level which will then allow researchers to employ the index constructed in this study again.

As stated earlier, this quantitative model is the first attempt to quantify a police union mechanism and estimate its effects on police abuse. Thus, while there are problems of endogeneity and other limitations, these findings are significant and establish a link between police abuse and a specific union mechanism.

225 Juris and Feuille, 1973. 


\section{Discussion}

While it is difficult to argue that protections in and of themselves cause abuse, there is a clear statistical relationship which achieves the primary aim of the paper and fills a serious gap in the literature. Unions insulate police abuse and fight to preserve the status quo, which is a process involving several mechanisms. This model discusses how police protections, which police unions create, may explain continued variation in abuse. While there is a possibility that unions will try to increase or remove protections, it is largely a rare phenomenon. ${ }^{226}$ In sum, this model establishes a quantitative linkage that supports the notion that police union mechanisms insulate police abuse. This is the first step of many in an attempt to better understand police unions and their relationship with abuse.

In this model, I employed police abuse as the dependent variable. There are four primary findings to highlight. First, police protections have a positive and significant relationship with police abuse, standing on its own. Second, police protections are an even stronger determinant when including race variables that have been established in past studies such as Minority Threat and Spatial. Third, police protections have no relationship with police killings of armed civilians but do have a relationship with abuse and deaths of police killings of Black civilians. In other words, police protections do determine cities with higher levels of police abuse but do not determine cities with more police killings in general, which further supports the notion that protections have a relationship with abuse. ${ }^{227}$

These findings suggest that the greater the level of police protections, the more likely there will be abuse. Thus, the culture of impunity theory may be plausible, in the sense that a reduction in deterrence may play a significant role in the decisions and behavior of police officers. ${ }^{228}$ Another way to view this model is thus: cities which have low levels of police protections are

\footnotetext{
226 Walker, 2008; Keenan and Walker, 2008; Huq and McAdams, 2016.

227 Appendix J includes alternative institutional variables such as use of force police and finds police protections to not only be significant but to have a larger effect on police abuse than use of force/deadly use of force policies. 228 Walker, 2016.
} 
also less likely to experience police abuse. In turn, the lack of police protections generates a greater deterrent effect and sustains a climate where officers are more considerate and cognizant of their actions. Therefore, it can be reasonably argued that this union mechanism - union contract protections - can be potentially creating an insulator-like effect for police abuse by removing the fear of consequences for officer misconduct. Again, it is plausible that while officers may not be cognizant of individual protections, many of the behaviors are learned informally from fellow officers.

The next logical question to ask is what explains the variation in police protections. Past studies on police unionism that have failed involve political variables which have been strong indicators of union strength in the literature concerning unions. Thus, the next part of the paper will explore different political variables that may be able to account for variation in the level of policeprotections. In so doing, the second part of this study will explore the political dimension of police unionism to better understand whether unions are restricted by politics. 


\section{CHAPTER 6}

\section{IDEOLOGICAL INFLUENCE ON UNIONISM}

The first part of this thesis establishes the relationship between police abuse and police protections which are created and supported by unions. It addressed an important gap in the literature, as while there had been analyses of the nature of police unionism in American criminology literature, there had been no cross-city tests of competing theories or intuitions about the role of police institutions in abuse. As the previous part of the thesis establishes, police unions use institutional protections that reduce deterrence and construct an atmosphere more accepting of police abuse against civilians. But what explains why some unions are able to sustain or create such mechanisms? Thus, it is now logical to explore variables that may explain variation in police protections. Literature in the field has been fairly apolitical, which has hindered the understanding of union abilities and why unions are effective maintaining at upholding the status quo. By this I mean the literature generally ignores potential political correlates of police institutions.

To examine the specific role of political ideology on police protections, I use the same city-level dataset and explore the political correlates of police protections. I will test the originally constructed index of police protections and use it as the dependent variable for this part of the study. I will cite a small sample of interviews for this part of the study to confirm suggestions 
and findings of past studies on ideological perceptions of officers. ${ }^{229}$ Thus, the political dimension explored is intended to inform whether ideological alliances can explain variation in the level of police protections. While the membership of the police unions has long been cited as supporters of more conservative candidates, unions in other areas have also been cited to receive better support and bargaining positions from liberal politicians and labour laws. Therefore, this section addresses the following questions: (1) Are officer perceptions valid in the thinking that they receive more support and protections in conservative areas? (2) Does city-level ideology or state-level ideology via bargaining rights determine variation in the level of police protections offered to officers?

\section{Empirical Model}

Returning to teacher unionism literature, Moe finds that unions formed strong alliances with the Democratic party throughout the course of the twentieth century. ${ }^{230}$ Moreover, this political alliance, in combination with a surge in unionism, helped introduce and pass strong labour laws. ${ }^{231}$ This in turn allowed teacher unions to create stronger contracts and craft the existing status quo. ${ }^{232}$ In sum, teacher unions' success in achieving stronger state labour laws was, in part, due to the alliance with the Democratic party. Another way to perceive this theory is that weak contracts are the product of weak state labour laws that are primarily advocated by conservative interests. ${ }^{233}$ While this remains true for teacher unionism, it is important to determine whether the same holds true for police unionism and police protections. In contrast to teacher unions, police unions have been observed to contain a more conservative membership and have been documented endorsing conservative candidates in

\footnotetext{
229 Appendix K.

230 Moe, 2015.

231 Moe, 2015. Dark, 1999.

232 Moe, 2012; Moe, 2015.

233 Freeman and Han, 2015.
} 
presidential elections, most recently the Fraternal Order of Police (FOP) endorsed President Donald Trump. ${ }^{234}$

There has yet to be a study that looks at a macro-view of police officer perceptions and voting patterns. However, existing literature discusses how police officers lean towards conservative stances and their recent endorsements of politicians during elections, at the presidential level, have all been Republican. ${ }^{235}$ Juris and Feuille find from interviews and surveys that officers adopt a hard-liner stance on crime "resulted in frequent police-union endorsements of, or informal membership for, political candidates who exhibit 'conservative stances on many social and political issues." 236 The majority of officers interviewed for this thesis, albeit a limited sample, explicitly stated that conservative governance is preferred and cited that they expect better protections and benefits. Additionally, media and advocacy groups have highlighted a "double standard" surrounding how the Republican party attacks teacher unions but carves out an exemption for police unions. ${ }^{237}$ This places police unions in a potentially cross-cutting situation since they naturally have pro-labour interests that may be at odds with fiscal conservative stances that fight to reduce union power. Thus, it is also reasonable to find, in line with officer perceptions, that officers receive better protections in areas with a greater conservative inclination. Consequently, the model will inadvertently test the validity of the perception that officers receive better protections in conservative areas. This model will, in turn, shed more light on another underexplored area which is whether police unionism has a different set of ideological alliances differing from their counterparts or how they may be just as susceptible.

\footnotetext{
${ }^{234}$ Juris and Feuille, 1973

235 Quick, 2017.

236 Juris and Feuille, 1973, P. 58.

237 Quick, 2017.
} 


\section{Data \& Methods}

In this chapter, I turn to analyzing the police protection index, constructed and employed in preceding chapters of this thesis, as the dependent variable to test whether the political ideology of a city or state labour laws has any relationship with the level of protections.

The unit of analysis is again the city, with the dataset of the 100 largest US cities. The dependent variable is the police protection index. The independent variables include political ideology, bargaining power, population, violent crime rate and size of police department. The political ideology index has been drawn from the "American Ideology Project" designed by political scientists Christopher Warshaw and Christopher Tausanovitch. ${ }^{238}$ The dataset provides ideological scores which are derived from the Annenberg National Election Study and the Cooperative Congressional Election study which was administered to 275,000 Americans. ${ }^{239}$ The authors use Item Response Theory to calculate the ideological scores for each city on a liberal-conservative continuum where -1 represents the most liberal and 1 represents the most conservative. ${ }^{240}$ This continuum will be more appropriate than a Republican-Democratic variable representing the affiliation of the mayor or city council, especially, since a majority of America's largest cities are Democratic. A binary measure would not capture the variation required to test the theory. While there are issues with employing this dataset, such as the fact that most of the cities which are observed in this study tend to lean towards the liberal end of the spectrum, the continuum creates some variation. Thus, this dataset solves problems of cities which may have a Democratic mayor but where many of his/her policies are right of center.

\footnotetext{
238 Tausanovitch and Warshaw, "American Ideology Project”, 2017. 239 Ibid.

240 Ibid.
} 
It is also important to consider that unions may be restricted in their ability to negotiate contracts because of conservative or liberal politics at the state-level, such as via the adoption of collective bargaining laws. The existence or lack thereof of bargaining abilitiy will be another political variable included in this model. This binary variable was extracted from the 2013 LEMAS dataset. ${ }^{241}$ Bargaining laws shed more light on the political ideology on the state-level, rather than the city level. Thus, it should be viewed as another type of political variable. Appendix $H$ has the list of ideological scores for each city examined in this study.

I will be using an OLS regression with regional fixed effects and standard errors which are clustered by region to test the relationship. There are concerns with generalizing from these results since the police protection index only covers the period from 2013-2016 and many of these protections were instituted at different instances in the past few decades. However, the political ideology index and status of bargaining of powers are the results of decades of politics. The "American Ideology Project" uses data that spans over a decade to derive the ideological scores for the cities, and many of these protections were enacted at different times throughout the past few decades.

To summarize, this model will first explore political ideology influence on police protections at the local-level and then investigate whether state-level politics may restrain or influence the level of police protections.

241 US DOJ, “LEMAS” Dataset, 2013. 


\section{Findings}

Figure 10 Density Plot | Political Ideology Densities Across America's Largest 100 Cities

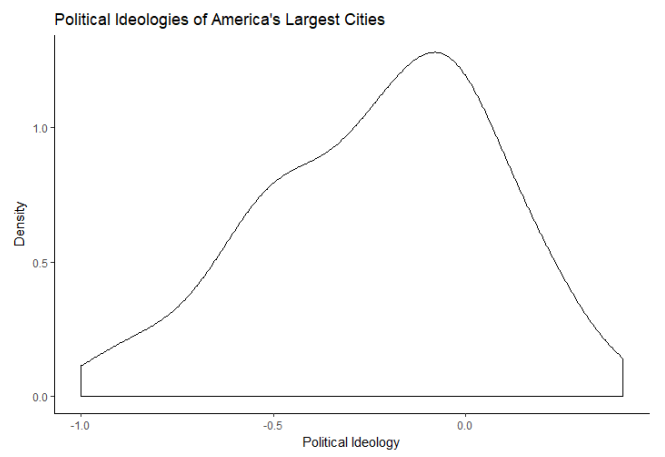

"Figure 10" includes a visual descriptive of the political ideology variable extracted from the

"American Ideology Project." It is apparent that America's largest cities are shifted toward the liberal direction of the continuum. However, there is variation among the continuum as illustrated by the density plot is more concentrated in the center.

Table 10 Regression Tables | Political Ideology and Police Protections

POLICE PROTECTIONS AND POLITICAL IDEOLOGIES

Dependent variable:

POLICE PROTECTIONS (PCA)

(1)

(2)

\begin{tabular}{lccc}
\hline POLITICAL_IDEOLOGY & -0.4292 & -0.1519 & -0.1519 \\
& $(0.4091)$ & $(0.3830)$ & $(0.3830)$ \\
BARGAINING RIGHTS & & $0.8092^{* * *}$ & $0.8092^{* * *}$ \\
POPULATION & $(0.1972)$ & $(0.1972)$ \\
& & $0.000001^{* * *}$ & $0.000001^{* * *}$ \\
VIOLENT CRIME RATE & $(0.000000)$ & $(0.000000)$ \\
& & 0.0171 & 0.0171 \\
SIZE OF DEPARTMENT & & $(0.0104)$ & $(0.0104)$ \\
& & $-0.0002^{* *}$ & $-0.0002^{* *}$ \\
\hline Observations & 100 & $(0.0001)$ & $(0.0001)$ \\
$\mathrm{R}^{2}$ & 0.0373 & 0.2325 & 100 \\
Adjusted R ${ }^{2}$ & -0.0033 & 0.1650 & 0.1650 \\
Residual Std. Error & $0.7514(\mathrm{df}=95)$ & $0.6855(\mathrm{df}=91)$ & $0.6855(\mathrm{df}=91)$ \\
\hline Note: & & ${ }^{*} \mathrm{p}<0.1 ;{ }^{* *} \mathrm{p}<0.05 ;{ }^{* * *} \mathrm{p}<0.01$
\end{tabular}


Figure 11 Scatterplot | Political Ideology and Police Protections

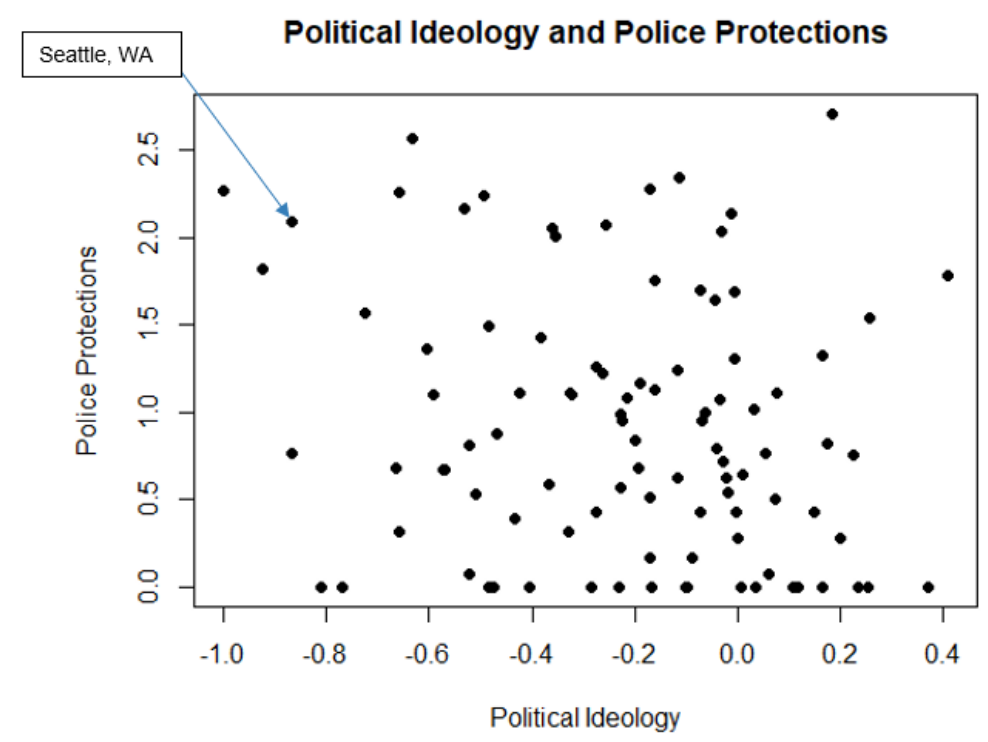

The results of the analysis are presented in Table 10. In column 1, I ask if a relationship exists between city-level ideology and police protections while controlling for necessary variables. The results present a null relationship, which is at odds with both predicted relationships: officers receive more protections under conservative leadership and officers receive better benefits from liberal governance. It is clear from "Figure 11" that there is no relationship between the two variables in question. Political ideology is statistically insignificant with a negative coefficient (-.42) indicating a leftward lean. One reason for this could be that there are not enough observations in the dataset. Another potential explanation which can be supported by union leaders is that "both conservatives and liberals want the support of the police" and that they should support the candidate who will provide more support. ${ }^{242}$ Interviews with union members have revealed that political alliances at the local-level are irrelevant. Instead, they argue that they will endorse anyone who will provide them with support. ${ }^{243}$ However, the most likely reason could be that there is an inherent sampling bias by only selecting the largest 100 American cities.

242 Burpo, DeLord, and Shannon, 1997, P. 101.

243 Phone Interview with Dallas Police Officer/DPA Member, Mar. 2, 2018. 
Nonetheless, the political ideology variable does not account for state political ideology, which may restrict or hinder the labour power in cities. For example, the city of Dallas may have an ideological score that may be left to the state of Texas.

Figure 12 Density Plot | Cities with Bargaining Rights

\begin{tabular}{|l|l|}
\hline $\begin{array}{l}\text { Bargaining Power } \\
(=1)\end{array}$ & $\begin{array}{l}\text { No Bargaining } \\
\text { Power }(=0)\end{array}$ \\
\hline 81 & 19 \\
\hline
\end{tabular}

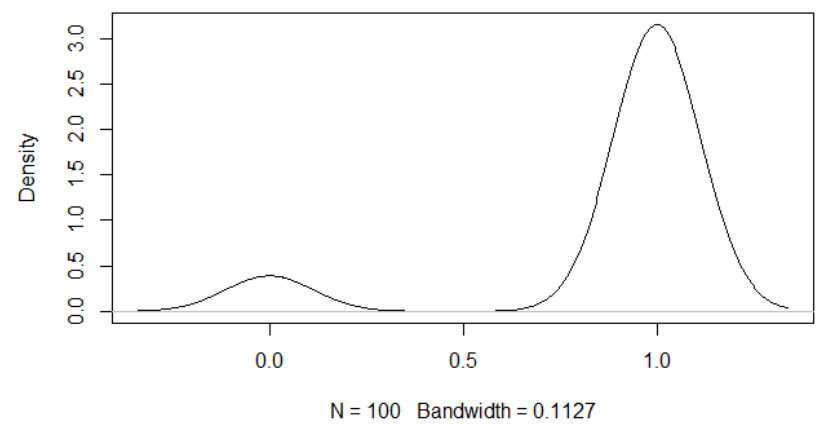

Column 2 includes the binary variable of whether the city allows for a law enforcement organization to bargain. While some states ban bargaining altogether, there are also states like Texas where some cities are permitted, and others do not. ${ }^{244}$ It is important to note that the majority of cities $(81 / 100)$ have some type of bargaining power ("Figure 12"). This does not mean that every city with bargaining power has protections: Dallas is one example. In column 2, the results present a positive and statistically significant relationship between bargaining and police protections (.81). In other words, cities which have bargaining powers that are primarily due to state laws will have a .81 -unit increase on the police protections index as opposed to cities that do not have collective bargaining powers. As noted above, this speaks to a larger discussion surrounding the layers of American federalism. Thus, while local politics are effective and powerful, they may be restrained by state or federal politics. ${ }^{245}$ "Figure 13 " represents the distribution of police protections by state. This is intentioned to demonstrate while state

\footnotetext{
${ }^{244}$ Some cities in states which restrict collective bargaining are still successful, at times, in negotiating another type of agreement like a meet $\&$ confer or similar type of labour agreement. Arlington, TX has no bargaining agreement, whereas, Dallas has a meet and confer and Austin has a stronger contract with protections. 245 Miller, 2008.
} 
variation is varied slightly, some states, such as Nevada are inherently limited in their variation because of the LEOBRs.

Figure 13 Circular Dendrogram | Police Protections by State

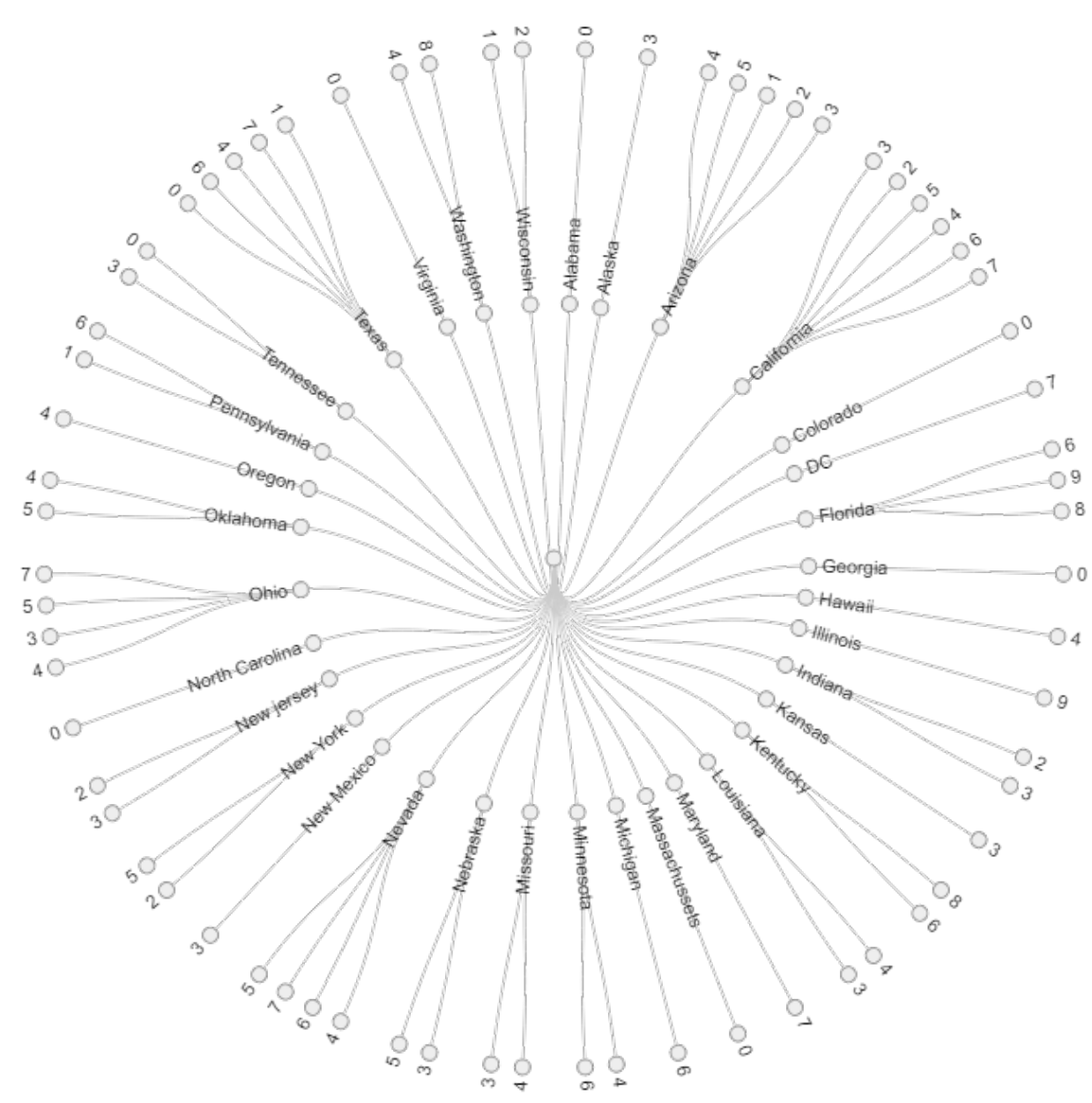

Furthermore, it is important not to contextualize collective bargaining powers in an apolitical light. Georgia, North Carolina, South Carolina, Texas, Tennessee, and Virginia are all states which do not allow any type of public-sector collective bargaining (including law enforcement organizations). ${ }^{246}$ As Freeman and Han highlight, "many conservative Republicans view public sector collective bargaining as usurping the authority of elected

246 Sanes and Schmitt, 2014; Hacker and Pierson, 2010. 
governments and as a barrier to an efficient low-cost public sector." ${ }^{247}$ Thus, it is reasonable to propose that restrictive collective bargaining laws are the product of successful conservative politics in state legislatures. ${ }^{248}$ In sum, this relationship may suggest that conservative politics at the state-level has restrained unions at the local-level to create police protections.

While the relationship is not as simple or as straightforward as political partisanship or party affiliation of the mayor, it is clear that there is an underlying political link.

\section{Discussion}

Two primary findings should be highlighted: the null relationship between ideology and the impact of bargaining powers. First, political ideologies of cities have no relationship with the level of police protections. Officer perceptions expected greater protections as we move towards the right of the ideology continuum. In other words, cities that are near center should have greater protections than those to the left. However, it appears that local-level politics does not have a salient effect on the level of police protections. Moreover, this conclusion may support Moe's theories on teacher unions in that unions employ politics from the top-down but rely on collective bargaining from the bottom-up. ${ }^{249}$ It is also likely that there is simply an insufficient number of observations $(\mathrm{N}=100)$ and that the study needs to include a larger set to confirm this finding. Instead, this null relationship reveals how union protections at the local level are not contingent on whether the city is more conservative or liberal. ${ }^{250}$

Second, collective bargaining powers which are granted by states and state labour laws have a significant impact on the level of protections which officers receive. There are outliers, e.g. some cities in Texas, but the variable is significant and substantively large. State-level

\footnotetext{
247 Freeman and Han, 2012, P.2.

248 Phone Interview with Dallas Police Officer/DPA Member, Mar. 1, 2018.

249 Moe, 2015.

250 Phone Interview with Dallas Police Officer/DPA Member, Mar. 1, 2018. This notion can be supported by a phone interview with a Dallas Police Officer/DPA Member who worked on DPA strategies.
} 
restrictions on collective bargaining make it difficult, at the very least, for unions to create contracts with greater police protections. Thus, states with weaker public-sector bargaining laws have a negative relationship with the level of police protections. In other words, notions that conservative states are more likely to safeguard police officers are not confirmed in this model. These findings are also significant because they run contrary to what officers may believe about police support and ideological alliances. Instead, it is plausible to suggest that conservative states may be inadvertently making it more difficult for police unions to safeguard their members. This model can be viewed as suggesting that state level liberalism vis-à-vis strong public-sector bargaining creates stronger police protections. This is not to say that there are not outliers: Florida stands as an example of a state with strong bargaining rights for law enforcement officers despite having weak bargaining laws for other publicsector workers, which supports the theory that officers receive support in conservative areas.

However, there are other factors to consider, such as the unique labour histories that vary across cities, as well as fiscal budgets. Police unions in some cities, such as Seattle, may benefit from their city's strong pro-labour stance in combination with residing in a state that permits collective bargaining. However, it is worth noting that Seattle is low in terms of the MT and Spatial variables and has historically not contained a large Black/Hispanic population which can serve as another potential reason for low levels of police abuse. On the other hand, a city like Dallas forces both the police and fire unions to band together to leverage the city into an agreement. ${ }^{251}$ Some cities have different dimensions of labour that may work against one another's interest. For example, in Chicago a police officer/FOP member described the contentious relationship between the fire and police unions where the city, historically, has given preference to the fire union. ${ }^{252}$ Examples include the city

251 Phone Interview with Dallas Police Officer/DPA Member, Mar. 1, 2018; Phone Interview with Dallas Police Officer/DPA Member, Jan. 18, 2018.

252 Interview with Chicago Police Officer/FOP Member, Chicago, IL - USA, Aug. 16, 2017. 
providing one union with better benefits or providing the fire union with a "me too" clause in their contract. ${ }^{253}$ In sum, the distinctiveness of each individual city that American federalism permits include a long list of variables that cannot be accounted for in this quantitative model.

To summarize, while this analysis cannot confirm if local-level political ideology is relevant to police protections, despite support from multiple theories, it does suggest that unions in states with conservative labour laws may be restrained in their ability to safeguard police protections and their officers.

${ }^{253}$ Interview with Chicago Police Officer/FOP Member, Chicago, IL - USA, Aug. 16, 2017. 


\section{CHAPTER 7}

\section{ALTERNATIVE EXPLANATIONS AND EVIDENCE OF MECHANISMS: CASE STUDIES OF CHICAGO \& DALLAS}

While the quantitative models are sufficient in linking a key union mechanism to police abuse, it is important to explore other dimensions which can explain how unions preserve the status quo and insulate abuse to better inform the study. This chapter will qualitatively explore alternative explanations for continued abuse, which involve variation in labour relationships and union structures. Police unions wield several different instruments in the political space to block reforms, reduce accountability, influence politicians, and advocate for legislation. ${ }^{254}$ These mechanisms are not mutually exclusive from one another and vary greatly across cities as a result of the unique histories that shape each city. More importantly, the sui generis nature of American federalism allows there to be such variation among cities. The effectiveness and power of unions are largely drawn from their activities at the local level, consistent with broader patterns of findings that show the effectiveness of US interest groups at the local level. ${ }^{255}$

254 Bies, 2017; Fisk and Richardson, 2016; McCormick 2015.
255 Miller, 2008. 
I begin with a federal perspective, which confirms the general correlates and results found in previous chapters surrounding the importance of police protections. Furthermore, it sheds light on other instruments that unions employ in the political arena and other instruments unions employ which weaken accountability systems. Subsequently, I will explore alternative explanations alluded to in the federal perspective with two case studies: Chicago, IL, and Dallas, TX. The former represents a city residing in a state with strong bargaining powers, whereas the latter depicts a weaker union with no police protections. Thus, this section is intentioned to explore alternative variables which can help explain why Dallas has been applauded for their policing practices and experiences low levels of abuse, whereas Chicago has high levels of abuse and has been cited as a department struggling with accountability. Moreover, the paired-study will present alternative variables for why Chicago has experienced more success in preserving the status quo, which is linked with continued abuse. In doing so, the differences between the unions will be discussed to illustrate how variation in the union structures and labour landscapes have contributed to creating a police department where officers are less incentivized to engage in citizen abuse.

\section{Federal Perspective on Unions}

The DOJ under the Obama administration took a more active role in reforming America's criminal justice system. The most notable efforts were carried out by the civil rights division of the DOJ. Jonathan Smith was appointed as chief of the special litigation unit for the DOJ Civil Rights Division (2010-2015) and was the individual responsible for "investigating law enforcement agencies across the country." ${ }^{256}$ Smith is arguably one of the most important federal actors involved and tasked with reforming America's most troubled police departments and was appointed for the sole purpose of reforming police

${ }^{256}$ Interview with Jonathan Smith, Washington, DC - USA, Sep. 7, 2017. 
departments. ${ }^{257}$ While acknowledging the hazards of generalizing from a single interview, his unique role should supply credibility to the evidence presented because of his proximity of the position to the question of interest - what part do police unions play in insulating police abuse?

Smith was responsible for the drafting and execution of consent decrees between cities and the DOJ. These decrees, if the city complied, force the implementation of different reforms tailored for the department. The intention of these reforms is to reform different aspects of policing culture and repair troubled departments, and every case reviewed by Smith, ranging from those New Orleans, LA to Ferguson, MO, involved reforms purposed to repair broken accountability systems. ${ }^{258}$ He argues that there are three obstacles in reforming a troubled police department:

1. Lack of acceptance "of the depth of the problem and that usually comes from the chief and political officials." 259

2. Union resistance. "Whenever there is an increase in accountability and almost every one of the cases ...the accountability system is broken. One of the functions of an accountability system is to discipline officers. One of the primary roles of police unions are to protect police officers." 260

3. Institutional inertia. "As human beings we all do things the way we've always done things... change is hard... trying to do things differently is really hard, especially, bringing in new systems and practices in place. There has to be a sustained effort to do it the new way for so long that it becomes the habit. And, that's why you need consent decrees to last for a period of years because

\footnotetext{
${ }^{257}$ Interview with Jonathan Smith, Washington, DC - USA, Sep. 7, 2017.

258 Ibid.

${ }^{259} \mathrm{Ibid}$.

260 Ibid.
} 
you need to have the reform in place and then there has a to be a period of sustained compliance." ${ }^{261}$

This description of the problem further supports the theory that unions have a part to play in combating policing reforms. Smith argues that this should not be surprising given that the interests of the police unions do not always match the interests of the departments. Departments are tasked with protecting and serving the community, unions are responsible for protecting their members. Thus, when departments have problems with accountability systems purposed to discipline officers, unions will have an interest to act against repairing these systems that make their members more vulnerable. This is a parallel that can be drawn to teacher unionism literature which discusses the vested interests of unions to safeguard their members. ${ }^{262}$

He then discussed some of the different instruments unions use to maintain the status quo. One of the first mechanisms that he discussed was union contract provisions. He recognizes that "police officers have and should have due process rights." ${ }^{263}$ However, he argues that certain provisions at times make it difficult to discipline officers: "what we have now are contract provisions all over the country that create weird artificial deadlines, which makes it impossible to consider certain relevant evidence, limited review and more." ${ }^{264}$ This qualitative evidence supports the findings from the primary models in this thesis. Nevertheless, contract protections, while problematic, are not the only mechanism used to insulate officers. Smith than discussed another underexplored area - the political arena.

\footnotetext{
${ }^{261}$ Interview with Jonathan Smith, Washington, DC - USA, Sep. 7, 2017.

262 Moe, 2015; Moe, 2012.

${ }^{263}$ Interview with Jonathan Smith, Washington, DC - USA, Sep. 7, 2017.

264 Ibid.
} 
Different media tactics, lawsuits, lobbying, electoral politics, and endorsements play a "major influential role" in the reform process. Furthermore, he argues that police unions are the most influential public-sector unions, a reality he credits to the fact that police unions have not been subjected to the same demonization as teachers' unions have experienced. ${ }^{265}$ In addition to being exempted from conservative attacks, Smith highlighted how unions are also able to neutralize progressive optimism with politicians who want to reform police departments and cites the example of Mayor Washington in Chicago. Thus, unions have "tremendous power and influence ... on chiefs and politicians." ${ }^{266}$ This interview evidence from a federal perspective is crucial, as it confirms findings in the first part of the study on contract protections reducing deterrence and insulating abuse. However, while Smith acknowledges the importance of contract protections, he also highlights that there are other spheres and instruments that unions employ to block reforms and hold the status quo.

\section{Case Selection: Chicago \& Dallas}

The qualitative data above helps confirm the findings of the quantitative model developed within this thesis, specifically the role of protections working to insulate abuse and weaken accountability. However, it also touches upon some additional nuances which could not be captured through quantitative means as well as alternative explanations for how unions preserve the status quo besides protections. Unions employ instruments and occupy spaces beyond those directly relevant to protecting police. Many of the mechanisms discussed outside police protections are difficult to quantify and will be explored in a qualitative study of two American cities: Chicago, Illinois, and Dallas, Texas.

\footnotetext{
265 Quick, 2017.

266 Interview with Jonathan Smith, Washington, DC - USA, Sep. 7, 2017.
} 
These two cities were chosen due to their demographic similarities and their extreme divergence in terms of police protections and abuse. ${ }^{267}$ They are similar in terms of racial composition ("Figure 14"), population, and most importantly stand as contrasts with each other in terms of abuse and police behavior outcomes. As already demonstrated via the index proposed in Chapter 4, the level of police protections varies significantly. Chicago has one of the highest levels of both police protections and abuse. ${ }^{268}$ In contrast, Dallas has the lowest possible score on the police protections index and has a lower level of abuse especially when considering that the Dallas homicide rate was $5.9 \%$ and the Chicago homicide rate was $5.4 \%{ }^{269}$

While they differ in terms of police protections, both cities house strong unions which employ similar instruments in the political arena. While other police unions exist in the cities, I will be focusing on the largest unions in the two cities, namely the Chicago Fraternal Order of Police, Lodge \#7 (Chicago FOP) and the Dallas Police Association (DPA). The Chicago FOP has an active and retired membership of 17,000 members. The DPA is the oldest and largest union in Dallas with 4,000 active and retired members. These dominant unions capture the vast majority of total constabularies and are the critical union actors in both cities.

\footnotetext{
${ }^{267}$ One limitation is the difference in size: Dallas has a population of 1.32 million and Chicago has a population of 2.73 million. Nevertheless, these two are the best for the analysis in comparison because they are relatively close in population in comparison to other potential cities. Again, this limitation also applies to the size of the department: Dallas has police force of nearly 3,400 officers, whereas, Chicago has nearly 12,000.

268 Appendix $G$ presents a table with variables of interest for each observation in the dataset.

${ }^{269}$ US Census Bureau, “2010 Census”, 2010.
} 


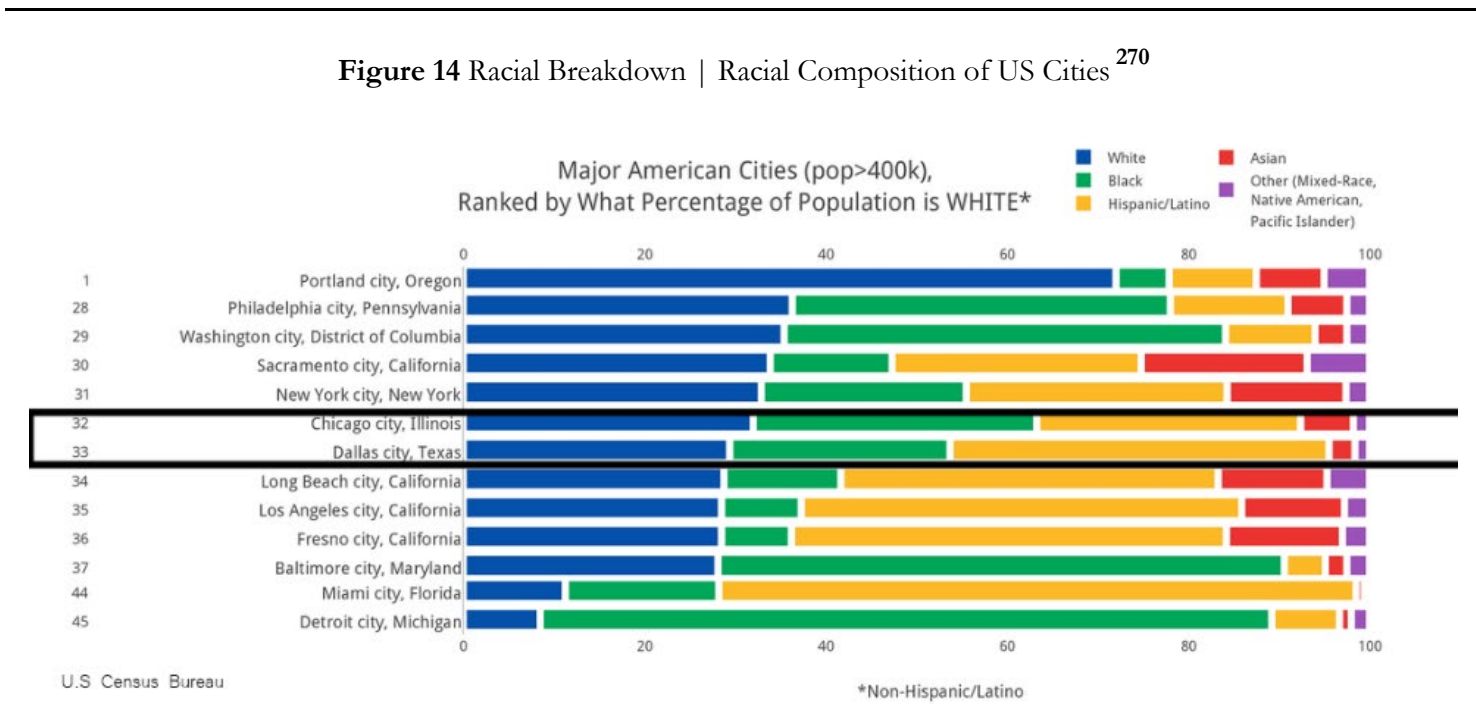

Finally, the two cities stand as contrasts in terms of reputation. Chicago has been viewed as a troubled police department in need of serious reforms. Following the release of the footage in the Laquan McDonald, a knife-wielding Black 17-year old who was shot 16 times by Chicago police officers while walking away from the officers, the Illinois Attorney General called upon the DOJ to investigate the Chicago Police Department. ${ }^{271}$ Some critics have labelled the report as a "scathing" review of the department which "found there to be a pattern and practice of excessive use of force violating the fourth amendment." ${ }^{272}$ In contrast, Dallas has been called a leader in police training and transparency. ${ }^{273}$

The above characteristics make the two cities ideal case studies for comparison to complement the statistical tests. Doing so allows two critical questions to be addressed: can police unions operating in states with weak collective bargaining laws still be serious opponents of reform by involving themselves in the political arena? And secondly, what are alternative explanations for why Dallas's unions have not been successful in blocking reforms and creating protections? These questions will be examined through qualitatative

\footnotetext{
270 This is an important characteristic since treatment of minority populations in the US, specifically in the criminal justice system, has been a determinant of cities with problems between communities and its police departments.

271 Ruthhart, Sweeney, and Byrne, 2017.

272 Kaste, 2017.

273 Robbins, 2016.
} 
evidence gathered through extenisve semi-structured interviews and an analysis of material drawn from the legal and public spheres, including: lawsuits, press statements, reports, and news articles. ${ }^{274}$

\section{Alternative Explanations}

President Barack Obama noted at the June 12, 2016 memorial of the five slain Dallas police officers that the "Dallas Police Department has been at the forefront of improving relations between police and the community." 275 The quantitative models in preceding chapters seem to support this statement and suggests that the Chicago FOP has taken a contrasting role by reducing transparency and having strong police protections in place which weaken accountability systems. ${ }^{276}$ This is not to say that Dallas has a perfect police department, as earlier chapters illustrate - abuse is still present in Dallas - but the weight of evidence renders Dallas as a department which is both more accountable and experiences more success with the implementation of prescribed policing practices and community oriented policing programs. ${ }^{277}$ Both Dallas police officers and city representatives were proud and highlighted the high standards of the Dallas police department and its community policing programs. ${ }^{278}$ The Chicago police interviews diverged in their view of the Department, and both city representative interviews in Chicago were critical of existing policing practices and behavior. ${ }^{279}$

Interviews conducted for this thesis have revealed alternative explanations which explain the lack of police protections in Dallas as well as the ineffectiveness of the DPA to insulate policing practices. The final question this thesis will address is whether union structures have a part to play in explaining variation in the type of police department. I have

\footnotetext{
274 Appendix $K$ provides information about the interviews.

275 Obama, 2016.

276 Lynch, 2017.

277 Robbins, 2016.

278 All Dallas police officer and city representatives' interviews. Appendix $K$.

279 All Chicago police officer and city representatives' interviews. Appendix K.
} 
identified two alternative explanation which pertain to union involvement and may have a part in producing the different outcomes observed in Chicago and Dallas: historical labour legacies creating the path for progressive reforms and ethnically pluralist unionism. ${ }^{280}$

\section{Historical Labour Legacies \& Progressive Reforms}

First, it is important to set the stage and consider the unique historical labour legacy that differs between US cities. As noted earlier, Miller highlights the amount of power American federalism allocates to localities and how special interests can shape policy, which could undermine Black and poor communities. ${ }^{281}$

In contrast to the Chicago FOP, the DPA and other unions in Dallas have not had the same power vis-à-vis state authorities, most likely because of weak state labour laws. As noted earlier, state-level labour laws have a negative relationship with police protections. However, another variable which may explain the lack of protections is the fact that the DPA and the Dallas Fire Fighters Association (DFFA) negotiate the "meet and confer" jointly. ${ }^{282}$ Naturally, this makes it difficult for the DPA to include provisions that are specific to the nature of policing. In sum, the "meet and confer" only touches upon the areas where the interests of both groups meet - fiscal matters pertaining to salary, fringe benefits and tenure (job security). ${ }^{283}$ Thus, issues revolving discipline and grievances are not included in the contract since these issues are not as salient for fire departments. ${ }^{284}$

Another important variable to consider is the effectiveness and success of progressive reformers. One Dallas appointed/elected city representative explained why Dallas was

280 There are other more prevalent reasons for the lack of reforms. This section only focuses on variables involving differences in union structures and variables hindering or promoting union abilities. The contract protections discussed in previous sections will not be discussed in this section.

281 Miller, 2008.

282 Phone Interview with Dallas Police Officer/DPA Member, Jan. 18, 2018.

283 Phone Interview with Dallas Police Officer/DPA Member, Mar. 1, 2018.

284 Interviews with Dallas Police Officers/DPA Members, Jan. 18, 2018; Feb. 16, 2018; Mar. 1, 2018; Mar. 2, 2018; Mar. 8,2018 , find the agreement to be sufficient and all agreed that there were enough protections for officers. 
more responsive to changing police practices and argued that the department and city were active since the late 1980 's in asking whether police officers are acting the right way. ${ }^{285} \mathrm{In}$ other words, city managers and police chiefs were not only more responsive to unpleasant situations between the department and its citizens but acted on addressing the problems by creating new initiatives to reform the department with better hiring practices, community policing programs and refining use-of-force policies. ${ }^{286}$

A final aspect to consider which may explain the lack of resistance by the DPA is that the period which the city representative discussed to be a time of reform also happens to line up with the public-sector union crack down of the 1980's. ${ }^{287}$ The combination of weak state labour laws compounded by anti-union attacks under the Reagan administration may help explain the vulnerability, lack of opposition and ease of policing reform in Dallas.

Dallas is a unique case, which illustrates how active involvement from the city and a lack of union opposition can conspire to produce greater accountability. City managers and police chiefs took a personal interest in implementing proactive policing practices and had the benefit of weak labour resistance, potentially making it easier to introduce and monitor reforms. The labour relationship, historical legacies, police chief, city administration in power, as well as environmental factors, can all work to create a potent force in reforming police departments and weakening union resistance to alter the status quo. In essence, anti-union climate coupled with weak labour laws allowed for progressive reformers at the local-level (Dallas) to take actions to respond to problems troubling the police department.

\footnotetext{
285 Phone Interview with Dallas Appointed/Elected City Representative, Jan. 7, 2018; Phone Interview with Dallas Police Officer/DPA Member, Feb. 16, 2018.

286 Phone Interview with Dallas Appointed/Elected City Representative, Jan 7, 2018.

287 McCartin, 2011.
} 


\section{Ethnic/Pluralistic Unionism}

Both a Dallas police officer and one Dallas city representative argued the importance and role of other competing unions in Dallas. ${ }^{288}$ The existence of different police unions in the same city naturally reduces the leveraging power of the dominant union and constructs the arena for politicians to use one against another. ${ }^{289}$ However, the existence of ethnic unions, most notably, The Black Police Association of Greater Dallas (BPAD) seems to have played a critical role in fragmenting the power of the DPA, advocating for reform, and supporting progressive reforms by the city which may have been opposed by the DPA. A Dallas police officer argued that the BPAD has played an active role in "investing in communities of color and reforming problematic policing practices." ${ }^{290}$

There are several reasons why ethnic and pluralistic unionism helped construct the space for better policing practices to be adopted in Dallas. First, ethnic unions resolve clear problems of representation in cities with one large union. As noted by one Chicago police officer, the Chicago FOP is predominantly White and minority member interests may be drowned out or become excluded. ${ }^{291}$ The BPAD has been cited advocating for better community policing programs and identifying racial bias in the police force. ${ }^{292}$ For example, recently the BPAD pushed the department to investigate a DPD officer who was expressing racist behavior on social media. ${ }^{293}$

In another example, a Dallas city representative highlighted that the BPAD makes it easier for the Chief of Police to remove bad officers, specifically, officers involved with patterns

\footnotetext{
288 Phone Interview with Dallas Appointed/Elected City Representative, Dec. 8, 2018; Phone Interview with Dallas Police Officer/DPA Member/BPAD member, Mar. 8, 2018.

289 Phone Interview with Dallas Appointed/Elected City Representative, Jan. 7, 2018; Phone Interview with Dallas Police Officer/DPA Member/BPAD Member, Feb. 16, 2018; Phone Interview with Dallas Police Officer/DPA Member, Mar. 2, 2018.

290 Phone Interview with Dallas Police Officer/DPA Member/BPAD Member, Mar. 8, 2018.

${ }^{291}$ Interview with Chicago Police Officer/FOP Member, Chicago, IL - USA, Aug. 27, 2017.

292 Phone Interview with Dallas Police Officer/DPA Member/BPAD Member, Feb. 16, 2018; Phone Interview, Dallas Police Officer/DPA Member, Jan. 18, 2018.

${ }^{293}$ Ramirez, 2016. Several white Dallas police officers were found involved with a social media "post showing a man in blackface with a noose around his neck as others give a thumbs-up sign."
} 
of racial bias and can rely on the BPAD for a statement of support. ${ }^{294}$ In Chicago, the FOP can rally against the chief and not be concerned with a competing union supporting the chief's decision.

One Dallas police officer argued the BPAD today is critical for supporting black commanders who may not receive the same support than their White counterparts, "Law enforcement is a conservative white male profession, how many of those officers do you think are fond of taking leadership from a black man... Your minority commanders will be the strongest advocates for community policing tactics." 295

In the past, Chicago has had Black police associations, most notably, the Afro American Police League (later changed to the African American Police League) who fought heavily for black officers in the late 1960's and early 1970's. ${ }^{296}$ However, one city representative stated that the organization has been essentially defunct for quite a long time and was only active around the civil rights movement. ${ }^{297}$ This notion is supported by Chicago police officer interviewees who made no mention of the organization. ${ }^{298}$ Nor is there anything today in Chicago which serves as an effective competing union to the Chicago FOP like the BPAD is to the DPA on matters addressing policing reform.

Therefore, it is plausible to suggest that the lack of a powerful and active organization to represent minority officer interests has allowed the Chicago FOP to be more effective in combating reforms, maintaining the status quo and creating an agenda that insulates police culture. In contrast, the DPA has had to be cognizant of their agenda and understand the ramifications of advocating for an issue that may draw opposition from the BPAD. In

\footnotetext{
294 Phone Interview with Dallas Appointed/Elected City Representative, Dec. 8, 2017.

295 Phone Interview with Dallas Police Officer/DPA Member/BPAD Member, Mar. 8, 2018.

296 Chandler, 2016.

297 Phone Interview with Chicago Appointed/Elected City Representative, Mar. 16, 2018.

298 Interviews from Chicago and Dallas police officers/union members. Whereas, every interviewee from Dallas made mention of the BPAD and their influence. Appendix $K$ includes a little more information on the number and date of interviews.
} 
other words, the DPA has to have an agenda which aligns with the BPAD in order to present a united front on other matters.

Moreover, while the DPA has been cited as being initially hostile towards certain types of reforms, they have also been found to be strong proponents and advocates for reforms that create better policing practices. ${ }^{299}$ One Dallas police officer stated that the DPA has always been known to push for professionalization and adopting better policing practices. ${ }^{300}$ One plausible argument is that the DPA, in part, started to support better policing practices earlier because chiefs and the city started adopting policies earlier. ${ }^{301}$ Simultaneously, the DPA may have been cognizant of the anti-union climate at the time and may have thought that it may be better to adhere to reforms and made a calculus of where to resist.

In sum, the city's proposal to implement reforms not only evaded the same level of hostility exhibited by the Chicago FOP, but the DPA and other unions started to adapt to the altered institutional inertia and support the reforms and agenda of competing unions focused on reforming troubling aspects of policing relating to race.

\section{Discussion}

While the study earlier established a link between police protections and police abuse, this chapter sought to employ qualitative evidence to better explore alternative explanations. This section began by qualitatively exploring a federal perspective which discussed unions' role and interest in weakening accountability systems. Moreover, the evidence confirms the general correlates from the first model and highlights the negative impact of police protections. It then touched upon alternative explanations for continued abuse and lack of reform. Despite a union - such as the DPA - not having strong police protections in their

\footnotetext{
299 Phone Interview with Dallas Appointed/Elected City Representative, Jan. 7, 2018.

300 Phone Interview with Dallas Police Officer/DPA Member, Mar. 1, 2018.

301 Phone Interview with Dallas Appointed/Elected City Representative, Jan. 7. 2018.
} 
contracts, the political arena allows unions to block reforms and insulate abuse.

Nonetheless, conducted interviews demonstrate and highlight alternative explanations for why Dallas varied in outcomes.

First, the qualitative evidence shows that labour laws restricting union power had a clear effect on restraining the DPA in preserving the status quo which was not experienced by the Chicago FOP. Specifically, weak labor laws coupled with progressive reform initiatives. Second, and arguably the most important, the existence of competing ethnic unions which not only served to reduce leveraging power as a competing union, but also served as a check on the DPA from adopting an agenda which insulates concerning aspects of police behavior and culture. Furthermore, it allowed for different issues to the forefront that would be drowned in larger, white-majority unions such as the Chicago FOP. Ethnic unions that find problems with status quo practices will serve as an important reform force against practices that are discriminatory towards their own members, which in turn; leads to the creation of fairer and better policing practices more reflective of the community. The combination of these factors may explain the conditions for why the DPA not only accepted some reforms but advocated alongside the DPA and local progressives on reform initiatives which created a more accountable department with less abuse. Therefore, the existence of another ethnic union pushing an agenda to create a more accountable department, an anti-union climate with weaker state labour laws, and the DPA cooperating on several reform initiatives may also serve as potential alternative explanations for why the Chicago FOP was more effective in maintaining the status quo. 


\section{CHAPTER 8}

\section{CONCLUSION}

How can we explain the continued abuse perpetrated by police and the variation therein?

The lack of compliance with laws and unfair treatment by the state's enforcement agency raises questions central to studies in political science. The manner in which the state's enforcement agency conducts itself and treats its citizens has been argued to characterize "the health of the democracy." ${ }^{302}$ Moreover, the perception that the enforcement agency, purposed to protect and serve the citizenry, is likely to use violence against specific groups creates problems of state legitimacy and the lack thereof.

Thus, we return to asking what explains variation in police abuse? Logically, we must investigate mechanisms which safeguard officers from accountability. Criminology has identified the role of police unions as an interest group which has a legal obligation to safeguard its members in fighting to weaken accountability mechanisms and block reforms purposed to increase accountability and transparency. Moreover, recent literature has confirmed a quantitative link between police unionism and abuse but failed to identify what union mechanism creates abuse. ${ }^{303}$ This thesis advances such a stance by arguing that police protections, found in union contracts and LEOBR, can best explain variation in levels

\footnotetext{
302 Huq, 2017.

${ }^{303}$ Dharmapala, et al, 2017.
} 
of police abuse. Evidence gathered by constructing and testing an original index of police protections that codified union contracts in America's largest 100 cities for provisions which have been argued to create problems for accountability support this conclusion. Moreover, when including race-relevant variables, which have been empirically demonstrated in the past to have a relationship with police abuse, police protections had a larger effect. While the construction of the index of police protections is a significant contribution to advancing the field, the positive and significant correlation with police abuse establishes a quantitative link between a specific union mechanism and police abuse.

Subsequently, after arguing why endogeneity is not an issue for this study, I then logically shifted the discussion toward attempting to understand variation in the level of protections. Drawing from theories found in special interest group and public-sector unionism, I test whether political ideology or variables relating to ideology have any bearing on the level of protections. Police unionism literature has largely been apolitical with the exception of qualitative studies observing lobbying strategies to block reforms purposed to increase accountability and transparency. ${ }^{304}$ This part of the study was aimed to better understand ideological alliances which have been alluded to, such as the uniqueness of police unions containing a large conservative membership living alongside the need for pro-labour support. Conservative politicians have been observed holding a "double standard" for defending police unions and attacking their public-sector counterparts, most notably in education. In contrast, literature on public-sector unionism and special interests argues that conservative interests fight to weaken state labour laws. Thus, do police unions benefit from conservative ideology or not? There is not enough data to confirm whether city-level ideology has any bearing on the level of protections. However, there was a positive and significant relationship between states which allowed

304 Bies, 2017; Fisk and Richardson, 2016. 
law enforcement to bargain and those which did not. In other words, state-level conservatism vis-à-vis weak labour laws and bargaining rights has a negative relationship with strong levels of protection within departments.

The third and last empirical chapter qualitatively confirmed how police protections and unions have a part to play in continuing abuse by weakening accountability systems and fighting against reforms. Moreover, it explored alternative explanations for how unions may be able to preserve status quo policing practices beyond the scope of police protections, which was illustrated via a paired-comparative study of Chicago and Dallas. This case study touched upon other variables, which first demonstrated the role of progressive reformers in states with weak labor laws. Second, and arguably most importantly, the existence and strength of competing ethnic unions which have agendas to reform departments naturally weaken the power of the dominant union and force the union to align with agendas from competing unions. Finally, in relation to the alternative variables, the DPA was also viewed as an advocate for some reforms which assisted in creating better accountability systems and allowed progressive reformers to experience more ease in creating reforms than in cities like Chicago, which has one large, predominantly White-membered, union, and where minority member interests may be drowned out.

As noted at the start of this thesis, police unions are not the only entity or force creating problems in America's police department. Problems with leadership, politicians, resistance by mid-level managers, institutional inertia and other factors also play a role in creating issues which continue or safeguard abusive practices and behaviours. The list also includes problems of accountability that are beyond the realm of departmental control, such as criminal procedures. A recent study, argues that prosecutors and the judiciary play a large role in continued problems of accountability because they fail to responsibly and seriously carry out criminal cases against officers, which is beyond the control of the department 
and unions. ${ }^{305}$ Moreover, as demonstrated by the qualitative evidence, unions only become a more salient adversary when departments start taking initiatives to reform. In other words, if the departments neglect or fail to accept that there is a problem, then there will be no initiatives to reform, and in turn no need for unions act. That being said, even when departments are the primary actors safeguarding abuse or neglecting to address problems of misconduct, contract protections can be in the background which can shape or justify police behavior.

To summarize, while unions are not the only reason for police abuse, this study has established a quantitative link between police protections, a key union mechanism, and police abuse. It has also illustrated that officer perceptions err in the belief that conservative support provides them with more protections. Instead, it demonstrates that state-level conservatism vis-à-vis weak labour laws may restrict the ability of unions to create police protections to safeguard officers. While the political model is not perfect, it is a first step in shedding light and understanding political and ideological alliances surrounding police unions. Moreover, the originally constructed index of police protections is an important resource and tool which can be employed in future studies to better understand and explore the impact of police unions. Finally, the qualitative evidence demonstrated that there are several alternative variables that can assist with explaining variation for how unions can insulate abuse and preserve the status quo, such as competing unionism, progressive reformers and unique labour relationships. This evidence also confirmed general correlates found in the study such as the role of police protections weakening accountability systems.

While the work taken by the Obama administration was a first step in reviving and strengthening the legitimacy of police departments across the US with initiatives like community-oriented

305 Pfaff, 2017. 
policing, the recent departure from these initiatives by the DOJ under Attorney General Jeff Sessions reflects a shift in a direction that can potentially reverse the reforms required to repair America's most troubled departments. ${ }^{306}$ Law enforcement agencies are entrusted with a monopoly of power by the state to protect and serve its communities. Because of this trust, mistreatment by police officers can lead a citizenry to distrust its state and its legitimacy. Thus, identifying variables which help may explain variation in police abuse is critical in strengthening a key democratic institution, and by extension democracy itself. Until law enforcement agencies across the US start a process of self-reflection which includes the reforming of police union mechanisms which weaken accountability systems and continue to shape police behavior, then the US will continue to experience a lack of trust by its minority populations for the state's enforcement agency and the very essence of democracy in America.

${ }^{306}$ Huq, 2017. 


\section{BIBLIOGRAPHY}

2010 US Census. US Census Bureau, 2010. https://www.census.gov/2010census/data/.

“2016 Racial Profiling Report.” Departmental. Dallas Police Department, n.d.

Adams, Roy J. "The Human Right of Police to Organize and Bargain Collectively." Police Practice and Research 9, no. 2 (May 1, 2008): 165-172. https://doi.org/10.1080/15614260802081329.

AFRO-AMERICAN POLICE LEAGUE, Renault Robinson, Howard Saffold, and Jerry Crawley, Plaintiffs, v. FRATERNAL ORDER OF POLICE, CHICAGO LODGE NO. 7, John M. Dineen, and City of Chicago, Defendants. FRATERNAL ORDER OF POLICE, CHICAGO LODGE NO. 7, Counter-Plaintiffs, No. No. 81 C 4004. (United States District Court, N.D. Illinois, Eastern Division. December 8, 1982).

Alford, Robert. "Designing Social Inquiry: Scientific Inference in Qualitative Research." Contemporary Sociology 24, no. 3 (May 1, 1995): 424-427. https://doi.org/10.2307/2076556.

Andenæs, Johannes. Punishment and Deterrence. University of Michigan Press, 1974.

Angrist, Josh, and Jörn-Steffen Pischke. Mostly Harmless Econometrics. Princeton University Press, 2009. https://press.princeton.edu/titles/8769.html.

Anonymous. Interview with Chicago Appointed/Elected City Representative. Phone, February 2, 2018.

—. Interview with Chicago Appointed/Elected City Representative. Phone, March 16, 2018.

—. Interview with Chicago Police Officer/FOP Member (01). In-Person, August 16, 2017.

—. Interview with Chicago Police Officer/FOP Member (02). In-Person, August 16, 2017.

—. Interview with Chicago Police Officer/FOP Member (03). In-Person, August 17, 2017.

—. Interview with Chicago Police Officer/FOP Member (04). In-person, August 17, 2017.

—. Interview with Chicago Police Officer/FOP Member (05). In-person, April 17, 2017.

- Phone Interview with Dallas Appointed/Elected City Representative. Phone, January 7, 2018.

. Phone Interview with Dallas Appointed/Elected City Representative. Phone, December 8, 2018.

. Phone Interview with Dallas Police Officer/DPA Member (01). Phone Conversation, January 18, 2018.

—. Phone Interview with Dallas Police Officer/DPA Member (03), March 1, 2018.

. Phone Interview with Dallas Police Officer/DPA Member (04), March 2, 2018.

. Phone Interview with Dallas Police Officer/DPA Member/BPAD Member (05). Phone, March 8, 2018.

- Phone Interview with Dallas Police Officer/DPA Union Member/BPAD Member (02), February 16, 2018. 
Anzia, Sarah F., and Terry M. Moe. "Do Politicians Use Policy to Make Politics? The Case of Public-Sector Labor Laws" 110, no. 4 (2016): 763-777.

https://doi.org/10.1017/S0003055416000484.

. "Public Sector Unions and the Costs of Government." The Journal of Politics 77, no. 1 (January 1, 2015): 114-127. https://doi.org/10.1086/678311.

Armstrong, David. "Second Chance for Cops." The Boston Globe, May 21, 2000. http://cache.boston.com/globe/metro/packages/civil_service/part1.htm.

Barber, Michael J. "Ideological Donors, Contribution Limits, and the Polarization of American Legislatures." The Journal of Politics 78, no. 1 (January 2016): 296-310.

https://doi.org/10.1086/683453.

Baumgartner, Frank, Christian Breunig, Christoffer Green-Pedersen, Bryan Jones, Peter Mortensen, Michiel Nuytemans, and Stefaan Walgrave. "Punctuated Equilibrium in Comparative Perspective." American Journal of Political Science, Michiel, 53, no. 3 (July 2009): 18.

Baumgartner, Frank R. Agendas and Instability in American Politics. American Politics and Political Economy. Chicago ; London: University of Chicago Press, 1993.

Baumgartner, Frank R., Bryan Jones, and James L. True. "Punctuated-Equilibrium Theory Explaining Stability and Change in Public Policymaking." In Theories of the Policy Process, edited by Paul Sabatier, 2nd ed., 58, 2006.

Beccaria, Cesare. On Crimes and Punishments. Prentice Hall, 1963.

Berg, Austin. "Chicago Police Unions Are Fighting to Destroy Decades of Complaint Records." Illinois Policy (blog), December 14, 2015. https://www.illinoispolicy.org/chicago-policeunions-are-fighting-to-destroy-decades-of-complaint-records/.

Berman, Sheri. "Case Studies and Theory Development in the Social Sciences." Perspectives on Politics 5, no. 1 (2007): 187-188. https://doi.org/10.1017/S1537592707070491.

Bies, Katherine J. "LET THE SUNSHINE IN: ILLUMINATING THE POWERFUL ROLE POLICE UNIONS PLAY IN SHIELDING OFFICER MISCONDUCT.” Stanford Law Journal 28 (2017): 41.

Blumer, Herbert. "Race Prejudice as a Sense of Group Position." Pacific Sociological Review 1, no. 1 (April 1, 1958): 3-7.

Bonanno, Emma. “'An Evidential Review of Police Misconduct: Officer versus Organization' by Emma Rose Bonanno," 2015. https://ir.lib.uwo.ca/ungradawards 2015/9/.

"Brazil: Police Abuse Unabated | Human Rights Watch.” Human Rights Watch. Accessed April 4, 2018. https://www.hrw.org/news/2018/01/18/brazil-police-abuse-unabated.

Brooks, L. W. "Police Descretionary Behavior: A Study of Style.” In Critical Issues in Policing. Waveland Press, 2005.

Buckler, Kevin G., and Steve Wilson. "Media Violence Effects." Encyclopedia of Criminological Theory, 2010.

Buckler, Kevin, and James D. Unnever. "Racial and Ethnic Perceptions of Injustice: Testing the Core Hypotheses of Comparative Conflict Theory." Journal of Criminal Justice 36, no. 3 (2008): 270-278. https://doi.org/10.1016/j.jcrimjus.2008.04.008.

"Building Momentum from the Ground Up: A Toolkit for Promoting Justice in Policing." Policy Recommendation. The Center for Popular Democracy, June 2015. 
Burpo, John, Ron DeLord, and Michael Shannon. Police Association Power, Politics, and Confrontation. Springfield, Illinois: Charles C Thomas, 1997.

Caldwell, Lucy. "It's Time to Take On Police Unions.” National Review, December 16, 2014. https://www.nationalreview.com/2014/12/its-time-take-police-unions-lucy-morrowcaldwell/.

Chandler, D.L. "Little Known Black History Fact: The Afro-American Patrolmen's League.” Black America Web (blog), October 31, 2016. https://blackamericaweb.com/2016/10/31/littleknown-black-history-fact-the-afro-american-patrolmens-league/.

Charrier, Kim. "Navigating Organizational Change: Strategic Management in Law Enforcement." Doctor of Education, Northern Arizona University, 2007.

Cherone, Heather. "City's Controversial Top Lawyer Stephen Patton Steps Down." DNAinfo Chicago, January 20, 2017. https://www.dnainfo.com/chicago/20170120/downtown/annavalencia-appointed-city-clerk-susana-mendoza-rahm-emanuel.

Coen, Jeff, and Stacy St. Clair. "Chicago’s Top Lawyer Preparing to Depart Amicably but amid Controversy." Chicago Tribune. January 19, 2017. ‥

Collier, David. "Understanding Process Tracing." PS, Political Science \& Politics 44, no. 4 (October 1, 2011): 823-830. https://doi.org/10.1017/S1049096511001429.

Collins, Allyson. Shielded from Justice: Police Brutality and Accountability in the United States. Human Rights Watch, 1998.

Comey, James. "Hard Truths: Law Enforcement and Race.” Speech, February 12, 2015. https://www.fbi.gov/news/speeches/hard-truths-law-enforcement-and-race.

Dallas Police Ass'n v. City of Dallas, 1999 U.S. Dist. LEXIS 12487 (1999).

Dallas Police Ass'n v. City of Dallas, 1999 U.S. Dist. LEXIS 12487, No. No. 3:93-CV-2481-P (United States District Court for the Northern District of Texas, Dallas Division August 11, 1999).

Dardick, Hal. "McCarthy 'cover-up' Accusations on Laquan McDonald Case Don't Square with Prior Remarks." chicagotribune.com, February 21, 2018.

http://www.chicagotribune.com/news/local/politics/ct-met-garry-mocarthy-rahm-emanuelaccusations-20180221-story.html.

Dark, Taylor E. The Unions and the Democrats: An Enduring Alliance. Ithaca ; London: ILR Press, 1999.

Davis, Angela, Bryan Stevenson, Marc Mauer, and Donald Wright. Policing the Black Man by Angela J. Davis, Bryan A. Stevenson, Marc Mauer, Bruce Western, Jeremy Travis, 2017. https:www.penguinrandomhouse.combooks537978policing-the-black-man-by-edited-andwith-an-introduction-by-angela-j-davis 9781101871270.

"Deadly Weapon Law and Legal Definition." USLegal, Inc. Accessed April 12, 2018. https://definitions.uslegal.com/d/deadly-weapon/.

Delaney, John Thomas, and Peter Feuille. "Collective Bargaining, Interest Arbitration, and the Delivery of Police Services." Review of Public Personnel Administration 5, no. 2 (1985): 21-36. https://doi.org/10.1177/0734371X8500500203. 
Dharmapala, Dhammika, Richard H. McAdams, and John Rappaport. "The Effect of Collective Bargaining Rights on Law Enforcement: Evidence from Florida." SSRN Electronic Journal, 2017. https://doi.org/10.2139/ssrn.3095217.

Doerner, Jill K., and Stephen Demuth. "The Independent and Joint Effects of Race/Ethnicity, Gender, and Age on Sentencing Outcomes in U.S. Federal Courts." Justice Quarterly 27, no. 1 (February 1, 2010): 1-27. https://doi.org/10.1080/07418820902926197.

Farber, Henry S. "Union Membership in the United States: The Divergence between the Public and Private Sectors*." Princteon University - Industrial Relations Section, September 19, 2005, 30.

Feuille, Peter, and John Delaney. "Collective Bargaining, Interest Arbitration, and Police Salaries." Industrial and Labor Relations Review 39, no. 2 (January 1, 1986): 228. https://doi.org/10.1177/001979398603900205.

Feuille, Peter, Wallace Hendricks, and John Thomas Delaney. The Impact of Collective Bargaining and Interest Arbitration on Policing. Institute of Labor and Industrial Relations, University of Illinois, 1983.

Finn, Peter. "Citizen Review of Police: Approaches and Implementation." National Institute of Justice - US Department of Justice, March 2001, 181.

Firestone, David. “The Rise of New York's Police Unions.” The Guardian, January 13, 2015. https://www.theguardian.com/us-news/2015/jan/13/new-york-police-unions-powerful.

Fisk, Catherine, and L. Song Richardson. "Police Unions." George Washington Law Review 85, no. 3 (May 2017): 88.

FRATERNAL ORDER OF POLICE, CHICAGO LODGE No. 7, Petitioner, v. ILLINOIS LABOR RELATIONS BOARD, LOCAL PANEL, and The City of Chicago, Respondents., No. No. 1-10-3215. (Appellate Court of Illinois, First District, First Division. November 21, 2011).

FRATERNAL ORDER OF POLICE, CHICAGO LODGE NO. 7; The Chicago Police Sergeants Association, PBPA Unit 156A; The Chicago Police Captains Association, PBPA UNIT 156C; and The Chicago Police Lieutenants Association, PBPA Unit 156B, Plaintiffs, v. The CITY OF CHICAGO; The Department of Police of the City of Chicago; and Chicago Tribune Company, LLC, Defendants (Fraternal Order of Police, Chicago Lodge No. 7, Plaintiff-Appellee; The Chicago Police Sergeants Association, PBPA Unit 156A, the Chicago Police Captains Association, PBPA Unit 156C, and the Chicago Police Lieutenants Association, PBPA Unit 156B, Plaintiffs and Intervenors-Appellees; The City of Chicago and the Department of Police of the City of Chicago, Defendants-Appellants; The Chicago Tribune Company, LLC, Defendant and Intervenor-Appellant)., No. Nos. 1-14-3884, $1-$ 15-0162, 1-15-1573. (Appellate Court of Illinois, First District, Sixth Division July 8, 2016).

Freeman, Richard. "What, If Anything, Can Labor Do to Rejuvenate Itself and Improve Worker Well-Being in an Era of Inequality and Crisis-Driven Austerity?” IDEAS Working Paper Series from RePEc, January 1, 2013.

Freeman, Richard B., and Eunice Han. "The War Against Public Sector Collective Bargaining in the US." Journal of Industrial Relations 54, no. 3 (June 1, 2012): 386-408. https://doi.org/10.1177/0022185612442279.

Freeman, Richard B., and Robert Valletta. "The Effects of Public Sector Labor Laws on Labor Market Institutions and Outcomes." When Public Sector Workers Unionize, January 1, 1988, 81 106. 
Freeman, Richard, Eunice Han, David Madland, and Brendan Duke. "How Does Declining Unionism Affect the American Middle Class and Intergenerational Mobility?" NBER Working Paper Series, October 1, 2015, n/a. https://doi.org/10.3386/w21638.

Freeman, Richard, Eunice Han, David Madland, and Brendan V. Duke. "How Does Declining Unionism Affect the American Middle Class and Intergenerational Mobility?" Working Paper. National Bureau of Economic Research, October 2015. https://doi.org/10.3386/w21638.

Fryer, Jr Roland G. "An Empirical Analysis of Racial Differences in Police Use of Force." Journal of Political Economy, 2016.

George, Alexander L. Case Studies and Theory Development in the Social Sciences. BCSIA Studies in International Security. Cambridge, Mass.; London: MIT Press, 2005.

Gibbs, Jack. Crime, Punishment, and Deterrence. Elsevier, 1975. https://books.google.co.uk/books?id=TGRHAAAAMAAJ\&q=Gibbs, $+1975 ; \& d q=G i b b s,+$ 1975;\&hl=en\&sa $=$ X\&ved=0ahUKEwjJt4 czKPaAhWHvhQKHVO9BQ0Q6AEIKTAA.

Gill, Charlotte, David Weisburd, Cody W. Telep, Zoe Vitter, and Trevor Bennett. “CommunityOriented Policing to Reduce Crime, Disorder and Fear and Increase Satisfaction and Legitimacy among Citizens: A Systematic Review." Journal of Experimental Criminology 10, no. 4 (December 2014): 399-428. https://doi.org/10.1007/s11292-014-9210-y.

Grimmer, Justin, and Brandon M. Stewart. "Text as Data: The Promise and Pitfalls of Automatic Content Analysis Methods for Political Texts." Political Analysis 21, no. 3 (2013): 267-297. https://doi.org/10.1093/pan/mps028.

Gupta, Vanita. "INVESTIGATION OF THE BALTIMORE CITY POLICE DEPARTMENT." Investigation. US Department of Justice, August 10, 2016.

. "Investigation of the Ferguson Police Department." Investigation. Washington, D.C.: US DOJ - Civil Rights Division, 2015.

Gupta, Vanita, and Jenny Yang. “ADVANCING DIVERSITY IN LAW ENFORCEMENT.” Washington, D.C.: US Department of Justice, October 2016.

Hacker, Jacob S., and Paul Pierson. Winner-Take-All Politics: How Washington Made the Rich Richer and Turned Its Back, on the Middle Class. New York; London: Simon \& Schuster, 2010.

Hersher, Rebecca. "DOJ: ‘Severely Deficient Training’ Has Led To Pattern Of Abuse By Chicago Police." NPR, January 13, 2017. https://www.npr.org/sections/thetwoway/2017/01/13/509646186/doj-severely-deficient-training-has-led-to-pattern-of-abuse-bychicago-police.

Hinkel, Dan. "Judge Rules against New Police Disciplinary Guidelines in Victory for FOP Chicago Tribune." Chicago Tribune, November 14, 2017. http://www.chicagotribune.com/news/local/breaking/ct-met-chicago-police-discipline-fop20171114-story.html.

Hirsch, Barry T., and Jeffrey M. Hirsch. "The Rise and Fall of Private Sector Unionism: What Comes Next?,” December 2005.

Holliday, Darryl, and Harry Backlund. "For Black Officers in Chicago, City's Police Crisis Calls for Action." City Bureau, December 7, 2015. https://www.citybureau.org/stories/2016/7/31/for-black-officers-in-chicago-citys-policecrisis-calls-for-action. 
Holmes, Malcolm D. "MINORITY THREAT AND POLICE BRUTALITY: DETERMINANTS OF CIVIL RIGHTS CRIMINAL COMPLAINTS IN U.S. MUNICIPALITIES.” Criminology 38, no. 2 (2000): 343-368. https://doi.org/10.1111/j.1745-9125.2000.tb00893.x.

Huq, Aziz Z. "Dignity, Not Deadly Force: Why Procedural Justice Matters for Modern Policing and Democracy." World Policy Journal 34, no. 2 (2017): 38-42.

https://doi.org/10.1215/07402775-4191602.

Huq, Aziz Z, and Richard H McAdams. "Litigating the Blue Wall of Silence: How to Challenge the Police Privilege to Delay Investigation." THE UNIVERSITY OF CHICAGO LEGAL FORUM, 2016, 43.

Jackman, Tom. "Fraternal Order of Police Union Endorses Trump - The Washington Post," September 16, 2016. https://www.washingtonpost.com/news/truecrime/wp/2016/09/16/fraternal-order-of-police-union-endorses-trump/.

Jacobs, David, and Robert M. O'brien. "The Determinants of Deadly Force: A Structural Analysis of Police Violence." American Journal of Sociology 103, no. 4 (January 1998): 837-62. https://doi.org/10.1086/231291.

Jick, Todd D. "Mixing Qualitative and Quantitative Methods: Triangulation in Action." Administrative Science Quarterly 24, no. 4 (1979): 602-11.

Jones, Bryan D., and Frank R. Baumgartner. "From There to Here: Punctuated Equilibrium to the General Punctuation Thesis to a Theory of Government Information Processing: Jones/Baumgartner: Punctuated Equilibrium Theory." Policy Studies Journal 40, no. 1 (February 2012): 1-20. https://doi.org/10.1111/j.1541-0072.2011.00431.x.

Juris, Hervey A., and Peter Feuille. Police Unionism: Power and Impact in Public-Sector Bargaining. Lexington, Mass: Lexington Books, 1973.

Kalven, Jamie. Citizens Police Data Project. Online Web Application. The Invisible Institute, 2015. https://beta.cpdb.co/data/bVB1qK/.

Kaste, Martin. "Chicago Police Often Used Excessive Force, DOJ Report Finds.” NPR, January 14, 2017. https://www.npr.org/2017/01/14/509807184/chicago-police-often-usedexcessive-force-doj-report-finds.

KEENAN, KEVIN M, and SAMUEL WALKER. "AN IMPEDIMENT TO POLICE ACCOUNTABILITY? AN ANALYSIS OF STATUTORY LAW ENFORCEMENT OFFICERS’ BILLS OF RIGHTS.” Boston University Law Review 14 (2005): 60.

Kelly, Kimbriell, Sarah Childress, and Steven Rich. "Justice Department Forces Police Reforms. But Have They Worked? | The Washington Post." The Washington Post. Accessed April 19, 2018. http://www.washingtonpost.com/.

King, Desmond S., and Robert C. Lieberman. "Ironies of State Building: A Comparative Perspective on the American State." World Politics 61, no. 3 (2009): 547-588. https://doi.org/10.1017/S0043887109000185.

King, Shaun. "King: No Convictions for Cops Charged with Murder in 2015 - NY Daily News," January 5, 2016. http://www.nydailynews.com/news/national/king-no-convictions-copscharged-murder-2015-article-1.2486371.

Klein, Joanne. "History of Police Unions." Encylopedia of Criminology and Criminal Justice, 2014.

Law Enforcement Management \& Administrative Statistics (LEMAS). 2013. Washington, D.C.: US Department of Justice, 2013. 
Levinson, Reade. "Special Report: Police Union Contracts Offer Shield of Protection." News. Reuters Investigates, January 13, 2017. https://www.reuters.com/investigates/specialreport/usa-police-unions/.

Lofca, Izzet. "A Case Study on Police Misconduct in the United States of America and an Applicable Model for the Turkish National Police.” University of North Texas, 2002.

Lynch, Loretta. "Justice Department Reaches Agreement with City of Baltimore to Reform Police Department's Unconstitutional Practices," January 12, 2017. https://www.justice.gov/opa/pr/justice-department-reaches-agreement-city-baltimorereform-police-department-s.

Magenau, John M., and Raymond G. Hunt. "Police Unions and the Police Role." Human Relations 49, no. 10 (October 1, 1996): 1315-43. https://doi.org/10.1177/001872679604901003.

Marks, Monique, and David A. Sklansky. Police Reform from the Bottom up: Officers and Their Unions as Agents of Change. Police Practice and Research. London: Routledge, 2012.

McCartin, Joseph Anthony. Collision Course; Ronald Reagan, the Air Traffic Controllers, and the Strike That Changed America. New York ; Oxford: Oxford University Press, 2011.

McCormick, Marcia L. "OUR UNEASINESS WITH POLICE UNIONS: POWER AND VOICE FOR THE POWERFUL?” SAINT LOUIS UNIVERSITY PUBLIC LAW REVIEW 35, no. 47 (2015): 20.

McKesson, DeRay, Samuel Sinyangwe, and Brittany Packnett. "Police Union Contracts and Police Bill of Rights Analysis.” Policy Recommendation. Campaign Zero, June 29, 2016.

. "Police Use of Force Policy Analysis." Policy Analysis. Campaign Zero, September 20, 2016.

Mettler, Suzanne, and Richard Valelly. "Introduction: The Distinctiveness and Necessity of American Political Development." In The Oxford Handbook of American Political Development. Oxford University Press, 2016.

. "Introduction: The Distinctiveness and Necessity of American Political Development Oxford Handbooks." In The Oxford Handbook of American Political Development. Oxford University Press, 2016. http://ezproxyprd.bodleian.ox.ac.uk:2067/view/10.1093/oxfordhb/9780199697915.001.0001/oxfordhb9780199697915-e-21.

Miller, Lisa Lynn. The Perils of Federalism [Electronic Resource]: Race, Poverty, and the Politics of Crime Control. Oxford Scholarship Online. Oxford: Oxford University Press, 2008. https:/ / ezproxyprd.bodleian.ox.ac.uk/login?url=http://dx.doi.org/10.1093/acprof:oso/9780195331684.001. $\underline{0001 .}$

Moe, Terry M. "Power and Political Institutions." Perspectives on Politics 3, no. 2 (2005): 215-233. https://doi.org/10.1017/S1537592705050176.

. "Teachers Unions and American Education Reform: The Politics of Blocking." The Forum 10, no. 1 (May 15, 2012). https://doi.org/10.1515/1540-8884.1494.

. "Vested Interests and Political Institutions." Political Science Quarterly 130, no. 2 (2015):

277-318. https://doi.org/10.1002/polq.12321.

Moe, Terry M., and Susanne Wiborg. The Comparative Politics of Education: Teachers Unions and Education Systems around the World. Cambridge, United Kingdom: Cambridge University Press, 2017. 
Morabito, Melissa. “American Police Unions: A Hindrance or Help to Innovation?” International Journal of Public Administration 37 (September 19, 2014). https://doi.org/10.1080/01900692.2014.934464.

"Negative Binomial Distribution: Use \& Misuse - Contagious Distribution, Overdispersion Parameter, Truncation, Log Series, Log Normal Distribution.” Accessed April 18, 2018. http://influentialpoints.com/Training/Negative binomial distribution use and misuse.ht $\underline{\mathrm{m}}$.

Neuhauser, Alan. "California Launches First Statewide System to Track Police Use of Force." US News \& World Report, September 22, 2016. https://www.usnews.com/news/articles/201609-22/california-launches-first-statewide-system-to-track-police-use-of-force.

Newman, Graeme. "ZIMRING \& HAWIKINS, 'Deterrence: The Legal Threat in Crime Control' (Book Review)." Journal of Criminal Justice 1, no. 2 (July 1, 1973): 169.

Norcross, Eileen. "WORKING PAPER PUBLIC-SECTOR UNIONISM: A REVIEW." George Mason University, May 2011. http:// financedocbox.com/Retirement Planning/72889226Working-paper-public-sector-unionism-a-review-by-eileen-norcross-no-may-2011.html.

Obama, Barack. "Dallas Shooting: President Obama Speaks at Memorial Service | Time." Speech, Dallas, Texas, July 12, 2016. http://time.com/4403543/president-obama-dallas-shootingmemorial-service-speech-transcript/.

O’Connor, Matt. "Police Lose False Arrest Lawsuit." Chicago Tribune, November 18, 2001. http://articles.chicagotribune.com/2001-11-18/news/0111180061 1 correctional-officermalicious-prosecution-false-arrest-lawsuit.

Parry, Hannah. "Eric Garner Chokehold Cop Sees Pay Jump to $\$ 120,000$ | Daily Mail Online.” Daily Mail, September 13, 2016. http://www.dailymail.co.uk/news/article-3786578/OutageEric-Garner-chokehold-cop-Daniel-Pantaleo-31-sees-pay-jump-20-000-jaw-dropping-120000-despite-desk-duty-demotion.html.

Pfaff, Jonathan. Locked In: The True Causes of Mass Incarceration_and How to Acbieve Real Reform. Basic Books, 2017. https://www.amazon.co.uk/Locked-Causes-Incarceration_and-AchieveReform/dp/0465096913.

Pogarsky, Greg, and Alex R Piquero. "Studying the Reach of Deterrence: Can Deterrence Theory Help Explain Police Misconduct?” Journal of Criminal Justice 32, no. 4 (July 2004): 371-86. https://doi.org/10.1016/j.jcrimjus.2004.04.007.

Police Shootings 2016 Database. Accessed April 12, 2018. https://www.washingtonpost.com/graphics/national/police-shootings-2016/.

Powers, James, and Dan Rosenblatt. International Association of Police Chiefs, 2001.

Putchinski, Laurence J. Union Influence and Police Expenditures [Electronic Resource]. Criminal Justice (LFB Scholarly Publishing LLC). New York: LFB Scholarly PubLLC, 2007. https:// ezproxyprd.bodleian.ox.ac.uk/login?url=http://ebookcentral.proquest.com/lib/oxford/detail.action ?docID=3016835.

Quick, Kimberly. "The Double Standard for Public-Sector Unions.” The Century Foundation (blog), October 17, 2017. https://tcf.org/content/commentary/double-standard-public-sectorunions/.

Ramirez, Marc. "Dallas' Black Police Association Calls for Inquiry into Social Media Post Depicting Man with Noose | News | Dallas News,” March 2016. 
https://www.dallasnews.com/news/news/2016/03/10/dallas-black-police-association-callsfor-inquiry-into-social-media-post-depicting-man-with-noose.

Robbins, Ted. "Dallas Has Been Called A Leader In Police Training, Transparency." NPR, July 8, 2016. https://www.npr.org/2016/07/08/485274691/dallas-has-been-called-a-leader-inpolice-training-transparency.

Ross, Cody T. "A Multi-Level Bayesian Analysis of Racial Bias in Police Shootings at the CountyLevel in the United States, 2011-2014.” Edited by Peter James Hills. PLOS ONE 10, no. 11 (November 5, 2015): e0141854. https://doi.org/10.1371/journal.pone.0141854.

Rushin, Stephen. "Police Union Contracts." DUKE LAW JOURNAL 66 (2017): 76.

Ruthhart, Bill, Annie Sweeney, and John Byrne. "AG Madigan Sues to Enforce Chicago Police Reform; Emanuel Pledges Cooperation - Chicago Tribune." Chicago Tribune. August 30, 2017. http://www.chicagotribune.com/news/local/politics/ct-emanuel-madigan-consent-decreemet-0830-20170829-story.html.

Sakala, Leah. "Breaking Down Mass Incarceration in the 2010 Census." Policy Group. Prison Policy Initiative, May 28, 2014. https://www.prisonpolicy.org/reports/rates.html.

Sanes, Milla, and John Schmitt. "Regulation of Public Sector Collective Bargaining in the States." Center for Economic anf Policy Research, March 1, 2014.

Schwartz, Joanna. "Police Indemnification.” NYU Law Review 89, no. 3 (June 2014). http://www.nyulawreview.org/issues/volume-89-number-3/police-indemnification.

Seawright, Jason. Multi-Method Social Science by Jason Seawrigbt. Cambridge University Press, 2016. https://www.cambridge.org/core/books/multi-method-socialscience/286C2742878FBCC6225E2F10D6095A0C.

Sherman, Lawrence W. Scandal and Reform: Controlling Police Corruption. University of California Press, 1978.

Silver, Nate. "Most Police Don't Live In The Cities They Serve.” FiveThirtyEight (blog), August 20, 2014. https://fivethirtyeight.com/features/most-police-dont-live-in-the-cities-they-serve/.

Sinyangwe, Samuel. Mapping Police Violence (version 2018). CSV, English. Campaign Zero, n.d.

—. Police Contracts Database (version 2018). CSV, English. Campaign Zero, 2016.

—. Use Of Force Dataset. Campaign Zero, 2018.

Skogan, Wesley G. “Why Reforms Fail.” Policing and Society 18, no. 1 (March 1, 2008): 23-34. https://doi.org/10.1080/10439460701718534.

Skolnick, Jerome H. "Enduring Issues of Police Culture and Demographics." Policing and Society 18, no. 1 (March 1, 2008): 35-45. https://doi.org/10.1080/10439460701718542.

Smith, Brad W., and Malcolm D. Holmes. "Police Use of Excessive Force in Minority Communities:. A Test of the Minority Threat, Place, and Community Accountability Hypotheses." Social Problems 61, no. 1 (February 1, 2014): 83-104. https://doi.org/10.1525/sp.2013.61.1.83.

Smith, Douglas A. "The Neighborhood Context of Police Behavior." Crime and Justice 8 (1986): 313-341. https://doi.org/10.1086/449126.

Smith, Jonathan. Interview with Jonathan Smith. In-Person, September 7, 2017. 
Spielman, Fran. "What Did Top City Lawyer Tell Aldermen about $\$ 5 \mathrm{M}$ Settlement for McDonald Family?” Chicago Sun-Times, December 6, 2015. https://chicago.suntimes.com/chicagopolitics/what-did-top-city-lawyer-tell-aldermen-about-5m-settlement-for-mcdonald-family/.

Steelworkers v. Enter Wheel \& Car Corp, No. 363 U.S. 593, 596 (US Supreme Court 1960).

Stinson, Philip M, and John Liederbach. "Police Integrity Lost: A Study of Law Enforcement Officers Arrested," n.d., 672.

Stinson, Phillip M. "Cops Shoot and Kill Someone about 1,000 Times a Year. Few Are Prosecuted. What Can Be Done?” Los Angeles Times, December 15, 2016. http://www.latimes.com/opinion/op-ed/la-oe-stinson-cop-shootings-20161215-story.html.

Stone, Christopher E., and Heather H. Ward. "Democratic Policing: A Framework for Action." Policing and Society 10, no. 1 (April 1, 2000): 11-45. https://doi.org/10.1080/10439463.2000.9964829.

Surowiecki, James. "Why Are Police Unions Blocking Reform? | The New Yorker." The New Yorker, September 19, 2016. https://www.newyorker.com/magazine/2016/09/19/why-arepolice-unions-blocking-reform.

Tacopino, Joe. “Justice Department Overhauls Eric Garner Investigation Team.” The New York Post. October 25, 2016. https://nypost.com/2016/10/25/justice-department-overhauls-ericgarner-investigation-team/.

Tangara. Data Mining Tutorials, December 24, 2009. http://data-miningtutorials.blogspot.co.uk/2009/12/varimax-rotation-in-principal-component.html.

TATOR, CAROL, FRANCES HENRY, Charles Smith, and Maureen Brown. Racial Profiling in Canada: Challenging the Myth of "a Few Bad Apples." University of Toronto Press, 2006. http://www.jstor.org/stable/10.3138/9781442678972.

Tausanovitch, Chris, and Christopher Warshaw. "Representation in Municipal Government." American Political Science Review 108, no. 03 (August 2014): 605-41. https://doi.org/10.1017/S0003055414000318.

Tausanovitch, Christopher, and Christopher Warshaw. American Ideology Project. Accessed April 20, 2018. http://americanideologyproject.com/.

Tennesse v. Garner, No. 471 U.S. 1 (U.S. Supreme Court 1985).

Terrill, William, and Jason R. Ingram. "Citizen Complaints Against the Police: An Eight City Examination.” Police Quarterly 19, no. 2 (June 2016): 150-79. https://doi.org/10.1177/1098611115613320.

The Counted. English. The Washington Post, n.d.

“The Dilemmas of Police Unions | Get-Tough.” Accessed April 16, 2018. https://alexbelkins.com/2017/04/14/the-dilemmas-of-police-unions/.

Tittle, CR. "LABELLING AND CRIME - AN EMPIRICAL EVALUATION (FROM LABELLING OF DEVIANCE.” Sage, 1980, 23.

Trejo, Stephen J. "The Effects of Overtime Pay Regulation on Worker Compensation." The American Economic Review 81, no. 4 (September 1, 1991): 719-740.

True, James, Bryan D. Jones, and Frank R. Baumgartner. "Punctuated-Equilibrium Theory Explaining Stability and Change in Public Policymaking." Edited by Paul Sabatier. Theories of the Policy Process, 2nd Edition, April 2006. 
Tyler, Tom R. "Procedural Justice, Legitimacy, and the Effective Rule of Law." Crime and Justice 30 (2003): 283-357.

Valderrama, Franklin Ulyses. FRATERNAL ORDER OF POLICE, CHICAGO LODGE NO. 7, Plaintiff, v. CITY OF CHICAGO, Defendant., No. No. 2016 CH 16529. (2017 WL 4070875 (Ill.Cir.Ct.) (Trial Order) Circuit Court of Illinois. County Department, Chancery Division General Chancery Section Cook County July 17, 2017).

Velicer, Wayne, and Douglas Jackson. "Component Analysis versus Common Factor Analysis Some Issues in Selecting an Appropriate Procedure." Multivariate Behavioral Research 25, no. 1 (1990): 1-28.

Waldron, Travis. "Brazilian Cops Are Killing More People Than Ever. Somebody Tell Madonna." HuffPost UK, November 1, 2017. http://www.huffingtonpost.com/entry/brazil-policeviolence-madonna-rio us 59f9dc68e4b0d1cf6e91f1ef.

Walker, Samuel. Taming the System: The Control of Discretion in Criminal Justice, 1950-1990. Oxford University Press, 1993.

. "The Neglect of Police Unions: Exploring One of the Most Important Areas of American Policing." Police Practice and Research 9, no. 2 (May 1, 2008): 95-112. https://doi.org/10.1080/15614260802081253.

Walker, Samuel. “Walker: Police Unions Create a 'Culture of Impunity’ for Officers.” Samuel Walker (blog), September 20, 2016. http://samuelwalker.net/2016/09/walker-police-unionscreate-a-culture-of-impunity-for-officers/.

Warshaw, Christopher, and Christopher Tausonovitch. American Ideology Project, 2017.

Weitzer, Ronald, and Steven A. Tuch. "Race and Perceptions of Police Misconduct." Social Problems 51, no. 3 (2004): 305-325. https://doi.org/10.1525/sp.2004.51.3.305.

. "REFORMING THE POLICE: RACIAL DIFFERENCES IN PUBLIC SUPPORT FOR CHANGE*." Criminology 42, no. 2 (May 2004): 391-416. https://doi.org/10.1111/j.1745-9125.2004.tb00524.x.

White, Halbert. “A HETEROSKEDASTICITY-CONSISTENT COVARIANCE MATRIX ESTIMATOR AND A DIRECT TEST FOR HETEROSKEDASTICITY.” Econometrica (Pre-1986) 48, no. 4 (May 1, 1980): 817. https://doi.org/10.2307/1912934.

Wilson, Reid. "GOP Plans New Assault on Unions.” The Hill, December 7, 2016. http://thehill.com/regulation/labor/309122-gop-plans-new-assault-on-unions.

Wilson, Steve, and Kevin Buckler. “The Debate over Police Reform: Examining Minority Support for Citizen Oversight and Resistance by Police Unions." American Journal of Criminal Justice 35, no. 4 (2010): 184-197. https://doi.org/10.1007/s12103-010-9079-x.

Wilson, Steve, Jihong Zhao, Ling Ren, and Steven Briggs. "The Influence of Collective Bargaining on Large Police Agency Salaries: 1990-2000.” American Journal of Criminal Justice 31, no. 1 (September 2006): 19-34. https://doi.org/10.1007/BF02885682.

“World Report 2018: Rights Trends in Brazil." World Report. New York, NY: Human Rights Watch, January 5, 2018. https://www.hrw.org/world-report/2018/country-chapters/brazil.

Wright, Valerie. "Deterrence in Criminal Justice: Evaluating Certainty vs. Severity of Punishment." Policy Recommendation. The Sentencing Project, November 2010. 
Zhao, Jihong, and Nicholas Lovrich. "Collective Bargaining and the Police: The Consequences for Supplemental Compensation Policies in Large Agencies." Policing: An International Journal 20, no. 3 (September 1, 1997): 508-18. https://doi.org/10.1108/13639519710180169. 


\section{APPENDICIES}

\section{Appendix A: 100 Largest Cities Included in Study:}

Albuquerque, NM; Anaheim, California; Anchorage, Alaska; Arlington, Texas; Atlanta, Georgia; Aurora, Colorado Austin, Texas; Bakersfield, California; Baltimore, Maryland; Baton Rouge, Louisiana; Birmingham, Alabama; Boston, Massachussets; Buffalo, New York; Chandler, Arizona; Charlotte, North Carolina; Chesapeake, Virginia; Chicago, Illinois; Chula Vista, California; Cincinnati, Ohio; Cleveland, Ohio; Colorado Springs, Colorado; Columbus, Ohio; Corpus Christi, Texas; Dallas, Texas; Denver, Colorado; Detroit, Michigan; Durham, North Carolina; El Paso, Texas; Fort Wayne, Indiana; Fort Worth, Texas; Fremont, California; Fresno, California; Garland, Texas; Glendale, Arizona; Greensboro, North Carolina; Henderson, Nevada; Hialeah, Florida; Honolulu, Hawaii; Houston, Texas; Indianapolis, Indiana; Irvine, California; Irving, Texas; Jacksonville, Florida; Jersey City, New Jersey; Kansas City, Missouri; Laredo, Texas; Las Vegas, Nevada; Lexington, Kentucky; Lincoln, Nebraska; Long Beach, California; Los Angeles, California; Louisville, Kentucky; Lubbock, Texas; Madison, Wisconsin; Memphis, Tennessee; Mesa, Arizona; Miami, Florida; Milwaukee, Wisconsin; Minneapolis, Minnesota; Nashville, Tennessee; New Orleans, Louisiana; New York, New York; Newark, New Jersey; Norfolk, Virginia; North Las Vegas, Nevada; Oakland, California; Oklahoma City, Oklahoma; Omaha, Nebraska; Orlando, Florida; Philadelphia, Pennsylvania; Phoenix, Arizona; Pittsburgh, Pennsylvania; Plano, Texas; Portland, Oregon; Raleigh, North Carolina; Reno, Nevada; Riverside, California; Rochester, New York; Sacramento, California; San Antonio, Texas; San Bernardino, California; San Diego, California; San Francisco, California; San Jose, California; Santa Ana, California; Scottsdale, Arizona; Seattle, Washington; Spokane, Washington; St.Louis, Washington; St.Paul, Minnesota; St.Petersburg, Florida; Stockton, California; Tampa, Florida; Toledo, Ohio; Tucson, Arizona; Tulsa, Oklahoma; Virginia Beach, Virginia; Washington, DC; Wichita, Kansas; Winston-Salem, North Carolina. 


\section{Appendix B: Additional Provision Identification and \& Word Phishing}

Additional provisions, not included in the "Police Union Contract Dataset" from campaign Zero, were found by manually combing through contracts and by employing Python word phishing algorithms. An example of one script which attempted to identify provisions relating to civilian oversight can be found below:

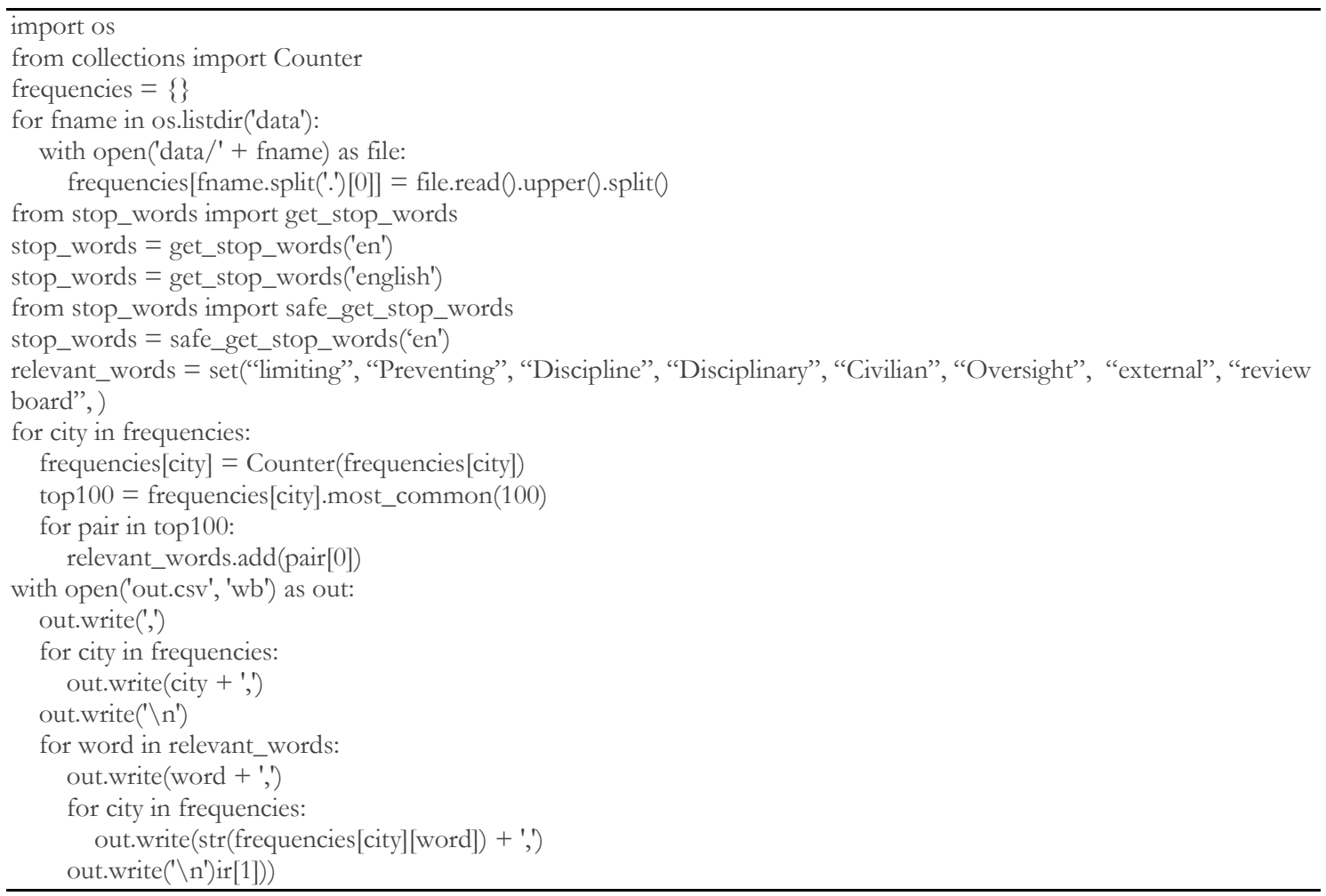

Additional provisions were found via manual codification. Each provision was individually considered and evaluated to determine whether it fits the criteria for any of the categories. Please see Appendix E for more information on codification. 


\section{Appendix C: Dependent Variable Filtering (Police Abuse)}

Cases of "Allegedly Armed" deaths involve an individual which may have posed a deadly threat to other civilians in his environment; this may include but is not limited to domestic violence, gang violence, and domestic and foreign terrorism. Admittedly, the unarmed filter and cases where a deadly weapon is not being wielded is not a perfect proxy for police abuse, but the methodology employed for classifying it as "unarmed" is rigorous and should add a degree of credibility for the labeling of some observations as abuse.

Next, I removed observations of civilians who have been killed by other law enforcement agencies not covered by the union contracts in question, such as federal agencies and local sheriff departments. Other agencies such as sheriff departments are worth exploring but are not within the scope of this study. Some sheriff departments have their own contracts and protections but have not been included in this study.

Additionally, I determined that those cases characterized as 'justified' are not excludable due to the fact that the majority of cases are under "pending investigation" or are blank. To further build credibility for this decision, only 27 of the 314 deaths which have been categorized under "abuse" were found to be justified or excusable by the department but will still be considered in the analysis. Included in the 26 justified observations is the death of Eric Garner, which is not only being disputed by the DOJ, but also resulted in the city of New York paying out a $\$ 5.9$ million settlement to the family of the deceased. ${ }^{307}$ Therefore, the "justified" filter will have no bearing on this study and will not be utilized to create a distinction between cases that constitute abuse or not.

307 Tacopino, 2016. 
The database codes an individual as unarmed if they are:

- "not holding any objects or weapons when killed

- holding household/personal items that were not used to attack others (cellphone, video game controller, cane, etc.)

- holding a toy weapon (BB gun, pellet gun, air rifle, toy sword)

- a person who dies in police custody after a police use of force or police neglect of their medical needs

- alleged to be armed by the police, but multiple independent witnesses maintain the person was unarmed, video evidence shows that the person was unarmed, and/or circumstances indicate it was physically impossible for that person to be armed (i.e. claiming a person shot themselves with their own gun while handcuffed and under surveillance in police custody after being searched for weapons)"

- not holding a "deadly weapon" or toy which looks like a "deadly weapon. (Inserted)

The following deaths have been removed as Unarmed for this study and excluded:

- (1) innocent bystander or hostage killed

- (2) a pedestrian or motorist accidentally hit by a police car or passengers in a vehicle chased by police with no weapon on them

- (3) drivers or passengers accidentally hit by a police car.

- (4) suicide deaths.

The vast majority of the "allegedly armed" observations were removed if individuals were wielding a "deadly weapon." State laws vary in their definition of a "deadly weapon" but is "generally defined as a firearm or anything manifestly designed, made, or adapted for the purposes of inflicting death or serious physical injury. The term includes, but is not limited to, a pistol, rifle, or shotgun; or a switch-blade knife, gravity knife, stiletto, sword, or dagger; or any billy, black-jack, bludgeon, or metal knuckles." Any civilian deaths which were wielding any such weapons were not included in the which is legally defined as may have been wielding a firearm, knife or another deadly weapon. This filtered down the observations to 314 occurrences of civilian deaths across America's largest 100 cities between 2013 and 2016. Deaths such as suicide, vehicular death and incidents of a similar nature have been excluded. It is problematic to generalize every "Allegedly Armed" case as abuse, to temporarily resolve the problem for limited temporal period allocated for the study, I have included deaths where the civilian is not armed with a "deadly weapon." The purpose 
of this was to broaden the range of the dependent variable since the greatest number of unarmed deaths was 19 . Alternatively, sifting through the 5,650 observations in the dataset individually would also require that I extrapolate information, resulting in some form of bias with missing or unreliable information in the assessment of the 5,557 incidents.

Additionally, I have not used the “justified' filter to exclude observations because the majority of cases are under "pending investigation" or are blank. To further build credibility for this decision, only 26 of the "unarmed" deaths were found to be justified or excusable by the department but will still be considered in the analysis. ${ }^{308}$ Included in the 26 justified observations is the death of Eric Garner, which is not only being disputed by the DOJ, but also resulted in the city of New York paying out a $\$ 5.9$ million settlement to the family of the deceased. ${ }^{309}$ Therefore, the "justified" filter will have no bearing on this study and will not be utilized to create a distinction between cases that constitute abuse or not.

As stated earlier, this proxy for abuse is not perfect and any significance suggests that there is some type of relationship which needs to be further explored with stronger proxies once the data becomes available. The index of police protections can be applied in future studies employing uniform excessive use of force data which would best capture the theory which attempted to be tested in this paper which is that police behavior is influenced by police protections.

It is also worth noting that regressions were also run with using "unarmed" deaths and the relationship had a similar significance.

\footnotetext{
308 While acknowledging that some unarmed deaths could be argued to be classified as justified, the "justified" filter in the database is problematic on a number of fronts.

309 Tacopino, 2016.
} 


\section{Appendix D: LEOBR \& Cities Lacking Contracts}

\section{The following cities do not have contracts:}

Arlington, TX; Atlanta, GA; Charlotte, NC; Colorado Springs, CO; Durham, NC;

Garland, TX; Greensboro, NC; Irving, TX; Lubbock, TX; New Orleans, LA; Norfolk, VA; Plano, TX; Raleigh, NC; Scottsdale, AZ; Virginia Beach, VA; Winston-Salem, NC.

The following cities refused to send contracts:

Birmingham, Chesapeake, and San Bernardino refused to send contracts.

\section{The following states have a Law Enforcement Officer Bill of Rights (LEOBR):}

California; Delaware; Florida; Illinois; Kentucky; Louisiana; Maryland; Minnesota; Nevada; New Mexico; Rhode Island; Virginia; West Virginia; Wisconsin

\section{Notes on LEOBR:}

There are as many as 20+ LEOBRs, depending on how you defined the term LEOBR (and at least 16-17 even if we use a narrow definition of the term LEOBR). LEOBRs also exist in Arkansas, Iowa, Oregon, Tennessee, Texas, and Wisconsin but do not include the protections discussed in this study nor are they termed LEOBR. But they provide the same basic protections. Some of them also have unusual stipulations, like that in Texas which applies more rigorously to cities like Houston, but not others, based on population.

Additionally, police union contracts are only one of many possible avenues through which police officers have obtained these protections. Some have obtained identical protections through LEOBRs, others through municipal codes, and some through city ordinance. For example, St. Paul's contract does not explicitly provide many of these protections. But the 
contract refers to municipal code or departmental regulations, which do include some of these protections.

Thus, a more in-depth study need to categorize different state legislation, department regulations and municipal codes that provide similar protections as contracts and LEOBR. Unfortunately, these are beyond the scope of this thesis which is focused solely on union contracts and LEOBR which are explicitly LEOBR. 


\section{Appendix E: Codification of Contracts}

In terms of the process of identifying and coding the contracts. I extracted the provisions into an excel spreadsheet for individual assessment of each provision in question. First, I classified them by examining the language of the provision and extracting their impact from the "Police Union Contract" dataset. For example, in the screenshot below, I individually evaluated each of the Baltimore provisions: some have been categorized and some others have not been categorized as problematic towards accountability. Those not categorized were not included in the PCA.

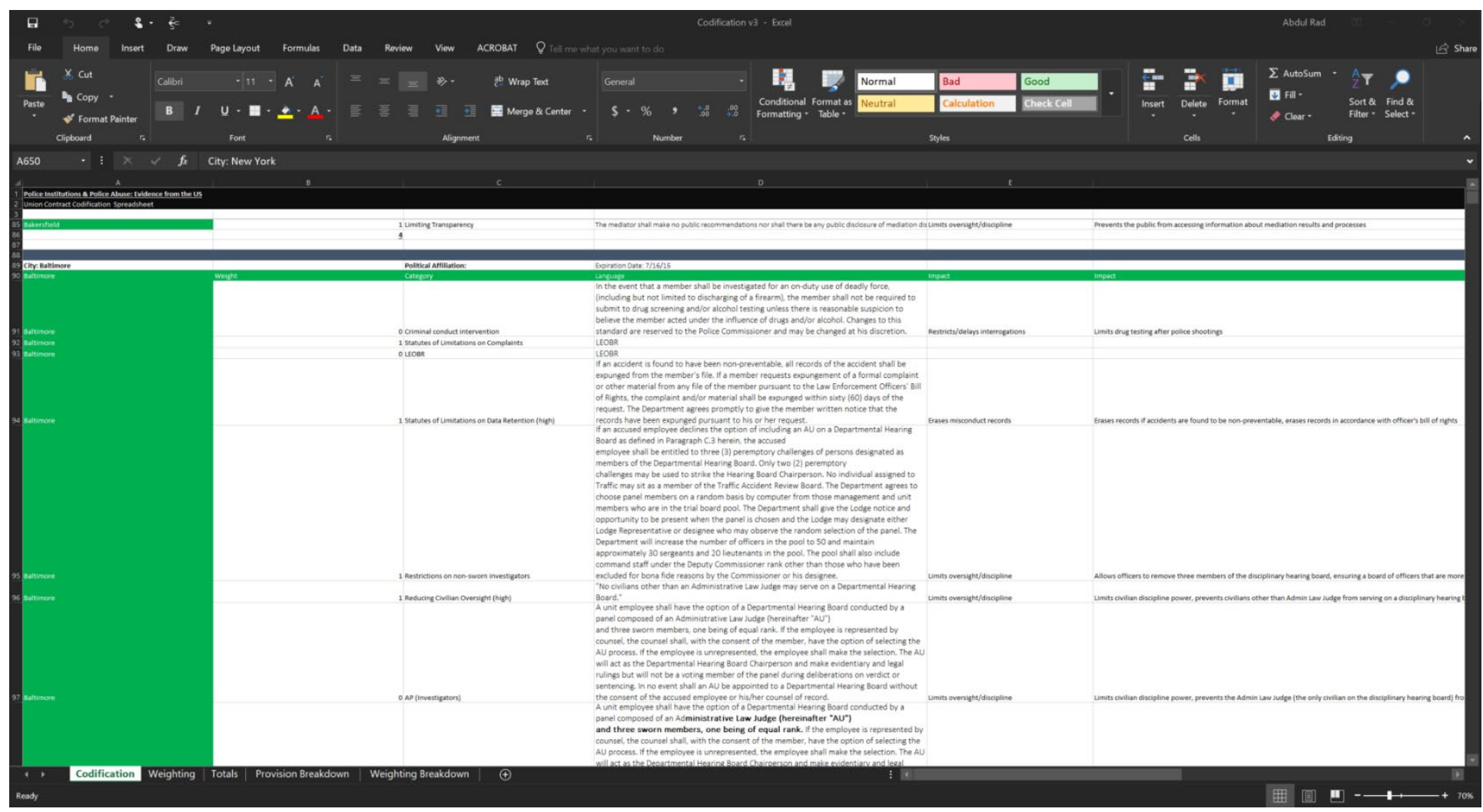

A copy of the spreadsheet which includes all of the provisions and classifications can be produced upon request. Unfortunately, there is over 1,200 rows in the spreadsheet and cannot be reproduced in this appendix (approximately 120 pages). 


\section{Appendix F: Principal Component Analysis}

The police association contracts were coded by singling out provisions which fall under the discussed categories of provisions discussed in the construction of the independent variable. For the purposes of this paper I have not clustered the different provisions along with each other which may create better and more refined scores. The dimensions and the factor loadings are listed below:

\begin{tabular}{|l|l|}
\hline Category of Provisions & Factor Loading \\
\hline Limiting Oversight & $\mathbf{0 . 2 7 6 6 0 9 9 1}$ \\
\hline Reducing/Preventing Oversight & $\mathbf{0 . 2 6 7 3 0 6 6 3}$ \\
\hline Statutes of Limitations on Data Retention \& Use (Sustained) & $\mathbf{0 . 2 5 1 5 0 4 4 8}$ \\
\hline Statutes of Limitations on Data Retention \& Use (Unsustained) & $\mathbf{0 . 0 7 0 8 3 3 7 9}$ \\
\hline Requiring City to Pay for Legal Costs and Indemnification & $\mathbf{0 . 3 9 5 4 4 4 3 1}$ \\
\hline Requiring City to Pay for Suspension/Fees & $\mathbf{0 . 2 7 8 3 5 3 1 4}$ \\
\hline Restrictions on Non-Sworn Investigators & $\mathbf{0 . 1 2 9 5 9 4 7 8}$ \\
\hline Advantages in Disciplinary Action & $\mathbf{0 . 2 6 0 1 2 9 8 7}$ \\
\hline Unfair Access to Investigative Materials (Full) & $\mathbf{0 . 3 3 5 8 5 9 8 1}$ \\
\hline Unfair Access to Investigative Materials (Partial) & $\mathbf{0 . 0 3 7 2 0 2 5 5}$ \\
\hline Statutes of Limitations on Filing of Complaint & $\mathbf{0 . 3 3 5 8 5 9 8 1}$ \\
\hline Limitations on Type of Complaint & $\mathbf{0 . 1 5 0 1 3 7 8}$ \\
\hline Formal Waiting Periods that Delay Investigations & $\mathbf{0 . 3 4 3 7 7 7 5 1}$ \\
\hline Limiting Transparency & $\mathbf{0 . 2 2 1 5 0 9 9 2}$ \\
\hline
\end{tabular}

The easiest method employed to construct an index is a simple additive index (also referred to as "summative") which was also created and employed. However, this approach assumes that the provisions are all equally important (and should thus be given equal weight) in measuring that dimension, and that each of the dimensions is equally important (and should be equally weighted) in constructing the final index. While acknowledging some of the benefits that an additive or "summative" index offers, these assumptions can become a vice moving forwards and are likely not faire assumptions to make as highlighted by scholars like Moe. ${ }^{310}$ Some rules and some dimensions are probably more important than others in capturing the restrictiveness of the contract.

310 Moe, 2009. 
Rules about teacher transfer rights, for example, would seem much more problematic for school managers_-and much more restrictive_-than requirements about the length of faculty meetings.

PCA is a better, more flexible way of constructing the index. For each dimension, I assume that the component rules are all measures of some latent concept (in this case being police abuse), and we can factor analyze them to create a single score for that dimension: a score that weights the components unequally, depending on their correlation with the latent variable. We can then assume that the fourteen-dimension scores are all measuring (in different ways, some better than others) the restrictiveness of the overall contract. The summary index of police protections can then be derived from all of the factor loadings reflecting their differential importance.

This was the approach adopted here, using the "Prin_Comp" function in R-Studio. In the above table, the number in the second column represents the factor loading. These loadings, as the numbers indicate, range between 0.02 and approximately .42. I have removed two of the items listed above-Statutes of Limitations on Complaints that are Unsustained and Limitations on type of complaint because their loadings were relatively low. In sum, provisions with weightings less than .10 were dropped.

Based on these loadings, composite indexes (single scores) were then created for each dimension, and the fourteen components were then treated as touching upon different areas of police protections which reduce deterrence. Of the remaining twelve dimensions, all have consequential roles to play in the overall index, but the most important are formal waiting periods, followed by restrictions on non-sworn investigators, Unfair Access to Investigative Materials (Full Access), and etc. It should not be surprising given that a 
recent qualitatively study was dedicated solely on the impact of "delay privileges" or waiting periods on reducing accountability. ${ }^{311}$

I have used a standard varimax rotation, as followed by Moe which maximizes the sum of the variances of the squared factor loadings. In sum, this makes the PC's factor loadings larger or in the near range of zero. This final index varies from 0 to 2.71, with a mean of .89 and a standard deviation of 0.75 . This is the key independent variable of the empirical analysis of this thesis. Moreover, the index of police protections will arguably be the largest contribution to advancing the study on police unionism from this thesis.

\section{PCA v. Factor Analysis}

It is also important to note that while the construction and methodology employed is similar to Moe's index of "restrictiveness", I have employed PCA instead of "Factor Analysis". ${ }^{312}$

Nevertheless, there is no large substantive difference as argued by Velicer and Jackson there is very little difference in the two methods, "the major conclusion of this article is that there is little basis to prefer either component analysis or factor analysis." 313

\footnotetext{
311 Huq and McAdams, 2016.

312 Moe, 2009.

313 Velicer and Jackson, 1990.
} 


\section{Appendix G: Index of Police Protections}

Below are the scores for the police protection index:

\begin{tabular}{|c|c|c|}
\hline \multicolumn{3}{|c|}{$\begin{array}{l}100 \text { Largest Cities in America } \\
\text { Police Protection Index }\end{array}$} \\
\hline & ADDITIVE & \\
\hline CITY & INDEX & PCA INDEX \\
\hline Albuquerque & 3 & 0.57 \\
\hline Anaheim & 3 & 0.43 \\
\hline Anchorage & 3 & 0.64 \\
\hline Arlington & 0 & 0 \\
\hline Atlanta & 0 & 0 \\
\hline Aurora & 0 & 0 \\
\hline Austin & 7 & 2.17 \\
\hline Bakersfield & 4 & 0.82 \\
\hline Baltimore & 7 & 2.26 \\
\hline Baton Rouge & 4 & 1 \\
\hline Birmingham & 0 & 0 \\
\hline Boston & 0 & 0 \\
\hline Buffalo & 2 & 0.32 \\
\hline Chandler & 3 & 1.02 \\
\hline Charlotte & 0 & 0 \\
\hline Chesapeake & 0 & 0 \\
\hline Chicago & 9 & 2.57 \\
\hline Chula Vista & 2 & 0.17 \\
\hline Cincinnati & 4 & 0.95 \\
\hline Cleveland & 5 & 1.11 \\
\hline Colorado Springs & 0 & 0 \\
\hline Columbus & 7 & 2.07 \\
\hline Corpus Christi & 4 & 1.31 \\
\hline Dallas & 0 & 0 \\
\hline Denver & 0 & 0 \\
\hline Detroit & 6 & 1.57 \\
\hline Durham & 0 & 0 \\
\hline El Paso & 6 & 1.7 \\
\hline Fort Wayne & 2 & 0.77 \\
\hline Fort Worth & 1 & 0.28 \\
\hline Fremont & 3 & 0.43 \\
\hline Fresno & 3 & 0.43 \\
\hline Garland & 0 & 0 \\
\hline Glendale & 5 & 0.76 \\
\hline Greensboro & 0 & 0 \\
\hline Henderson & 6 & 1.33 \\
\hline Hialeah & 8 & 2.34 \\
\hline Honolulu & 4 & 0.59 \\
\hline Houston & 7 & 2.28 \\
\hline Indianapolis & 3 & 0.63 \\
\hline
\end{tabular}


Police Institutions and Police Abuse: Evidence from the US

\begin{tabular}{|c|c|c|}
\hline Irvine & 4 & 0.68 \\
\hline Irving & 0 & 0 \\
\hline Jacksonville & 9 & 2.71 \\
\hline Jersey City & 3 & 0.88 \\
\hline Kansas City & 4 & 1.43 \\
\hline Laredo & 4 & 0.95 \\
\hline Las Vegas & 7 & 2.04 \\
\hline Lexington & 6 & 1.64 \\
\hline Lincoln & 3 & 0.63 \\
\hline Long Beach & 2 & 0.17 \\
\hline Los Angeles & 6 & 1.26 \\
\hline Louisville & 8 & 2.24 \\
\hline Lubbock & 0 & 0 \\
\hline Madison & 1 & 0.28 \\
\hline Memphis & 3 & 0.67 \\
\hline Mesa & 2 & 0.32 \\
\hline Miami & 6 & 1.78 \\
\hline Milwaukee & 2 & 0.39 \\
\hline Minneapolis & 6 & 1.22 \\
\hline Nashville & 0 & 0 \\
\hline New Orleans & 3 & 0.54 \\
\hline New York & 2 & 0.53 \\
\hline Newark & 2 & 0.68 \\
\hline Norfolk & 0 & 0 \\
\hline North Las Vegas & 5 & 1.08 \\
\hline Oakland & 4 & 0.77 \\
\hline Oklahoma City & 5 & 1.54 \\
\hline Omaha & 5 & 1.11 \\
\hline Orlando & 6 & 1.69 \\
\hline Philadelphia & 1 & 0.07 \\
\hline Phoenix & 4 & 0.79 \\
\hline Pittsburgh & 6 & 1.49 \\
\hline Plano & 0 & 0 \\
\hline Portland & 4 & 1.1 \\
\hline Raleigh & 0 & 0 \\
\hline Reno & 4 & 1.07 \\
\hline Riverside & 3 & 0.43 \\
\hline Rochester & 5 & 1.36 \\
\hline Sacramento & 5 & 1.11 \\
\hline San Antonio & 7 & 2.14 \\
\hline San Bernardino & 4 & 1.24 \\
\hline San Diego & 6 & 2.01 \\
\hline San Francisco & 7 & 2.27 \\
\hline San Jose & 6 & 1.1 \\
\hline Santa Ana & 3 & 1.17 \\
\hline Scottsdale & 1 & 0.07 \\
\hline Seattle & 8 & 2.09 \\
\hline Spokane & 4 & 1.13 \\
\hline
\end{tabular}


Police Institutions and Police Abuse: Evidence from the US

\begin{tabular}{ccc}
\hline St. Louis & 3 & 0.81 \\
St. Paul & 4 & 0.67 \\
St. Petersburg & 6 & 2.05 \\
Stockton & 5 & 0.84 \\
Tampa & 6 & 1.76 \\
Toledo & 3 & 0.51 \\
Tucson & 5 & 0.99 \\
Tulsa & 4 & 0.5 \\
Virginia Beach & 0 & 0 \\
Washington & 7 & 1.82 \\
Wichita & 3 & 0.72 \\
Winston-Salem & 0 & 0 \\
\hline
\end{tabular}


Appendix H: Table of Key Variables

The table below includes the primary variables of interest which are explored in the quantitative models of the paper.

\begin{tabular}{|c|c|c|c|c|c|}
\hline \multicolumn{6}{|c|}{ POLITICAL IDEOLOGY, PROTECTIONS, ABUSE \& MORE } \\
\hline CITY & $\begin{array}{l}\text { POLITICAL } \\
\text { IDEOLOGY }\end{array}$ & $\begin{array}{c}\text { POLICE } \\
\text { PROTECTIONS }\end{array}$ & $\begin{array}{l}\text { ABUSE } \\
\text { (Filtered) }\end{array}$ & $\begin{array}{l}\text { UNARMED } \\
\text { DEATHS }\end{array}$ & DEATHS \\
\hline Albuquerque & -0.22643 & 0.57 & 3 & 0 & 21 \\
\hline Anaheim & 0.148424 & 0.43 & 3 & 3 & 9 \\
\hline Anchorage & 0.010425 & 0.64 & 1 & 0 & 9 \\
\hline Arlington & 0.163176 & 0 & 4 & 1 & 10 \\
\hline Atlanta & -0.47692 & 0 & 2 & 2 & 8 \\
\hline Aurora & 0.033927 & 0 & 4 & 1 & 10 \\
\hline Austin & -0.53124 & 2.17 & 5 & 4 & 23 \\
\hline Bakersfield & 0.172855 & 0.82 & 5 & 7 & 22 \\
\hline Baltimore & -0.65715 & 2.26 & 11 & 9 & 28 \\
\hline Baton Rouge & -0.06169 & 1 & 3 & 3 & 10 \\
\hline Birmingham & -0.34501 & 0 & 4 & 4 & 7 \\
\hline Boston & -0.80869 & 0 & 1 & 0 & 9 \\
\hline Buffalo & -0.65936 & 0.32 & 0 & 0 & 2 \\
\hline Chandler & 0.031155 & 1.02 & 0 & 0 & 2 \\
\hline Charlotte & -0.16597 & 0 & 1 & 1 & 16 \\
\hline Chesapeake & 0.106933 & 0 & 2 & 2 & 2 \\
\hline Chicago & -0.63316 & 2.57 & 29 & 19 & 68 \\
\hline Chula Vista & -0.08889 & 0.17 & 1 & 0 & 2 \\
\hline Cincinnati & -0.2239 & 0.95 & 3 & 3 & 10 \\
\hline Cleveland & -0.42448 & 1.11 & 5 & 4 & 7 \\
\hline Colorado Springs & 0.23398 & 0 & 1 & 1 & 6 \\
\hline Columbus & -0.25519 & 2.07 & 2 & 2 & 29 \\
\hline Corpus Christi & -0.0066 & 1.31 & 2 & 2 & 5 \\
\hline Dallas & -0.23051 & 0 & 5 & 4 & 31 \\
\hline Denver & -0.48278 & 0 & 1 & 3 & 19 \\
\hline Detroit & -0.72535 & 1.57 & 3 & 1 & 9 \\
\hline Durham & -0.47351 & 0 & 1 & 2 & 7 \\
\hline El Paso & -0.07294 & 1.7 & 4 & 4 & 11 \\
\hline Fort Wayne & 0.052794 & 0.77 & 2 & 0 & 8 \\
\hline Fort Worth & -0.00045 & 0.28 & 1 & 0 & 17 \\
\hline Fremont & -0.27392 & 0.43 & 1 & 0 & 5 \\
\hline Fresno & -0.00411 & 0.43 & 4 & 4 & 18 \\
\hline Garland & 0.115976 & 0 & 0 & 0 & 4 \\
\hline Glendale & 0.225413 & 0.76 & 1 & 1 & 7 \\
\hline Greensboro & -0.40436 & 0 & 0 & 0 & 4 \\
\hline Henderson & 0.165395 & 1.33 & 1 & 0 & 5 \\
\hline Hialeah & -0.11221 & 2.34 & 3 & 1 & 4 \\
\hline Honolulu & -0.36763 & 0.59 & 2 & 1 & 10 \\
\hline Houston & -0.16994 & 2.28 & 9 & 8 & 49 \\
\hline
\end{tabular}




\begin{tabular}{|c|c|c|c|c|c|}
\hline Indianapolis & -0.1168 & 0.63 & 6 & 6 & 24 \\
\hline Irvine & -0.19392 & 0.68 & 1 & 1 & 0 \\
\hline Irving & 0.005855 & 0 & 0 & 0 & 6 \\
\hline Jacksonville & 0.18249 & 2.71 & 10 & 9 & 32 \\
\hline Jersey City & -0.46779 & 0.88 & 1 & 1 & 6 \\
\hline Kansas City & -0.38156 & 1.43 & 0 & 0 & 19 \\
\hline Laredo & -0.06993 & 0.95 & 2 & 2 & 6 \\
\hline Las Vegas & -0.02991 & 2.04 & 5 & 5 & 41 \\
\hline Lexington & -0.04345 & 1.64 & 2 & 0 & 4 \\
\hline Lincoln & -0.02081 & 0.63 & 0 & 0 & 2 \\
\hline Long Beach & -0.16944 & 0.17 & 7 & 5 & 20 \\
\hline Los Angeles & -0.27494 & 1.26 & 19 & 14 & 100 \\
\hline Louisville & -0.49431 & 2.24 & 3 & 2 & 12 \\
\hline Lubbock & -0.10173 & 0 & 0 & 0 & 3 \\
\hline Madison & 0.199958 & 0.28 & 1 & 0 & 6 \\
\hline Memphis & -0.56882 & 0.67 & 5 & 4 & 17 \\
\hline Mesa & -0.32797 & 0.32 & 2 & 2 & 15 \\
\hline Miami & 0.409549 & 1.78 & 8 & 6 & 9 \\
\hline Milwaukee & -0.43469 & 0.39 & 4 & 1 & 12 \\
\hline Minneapolis & -0.26178 & 1.22 & 1 & 2 & 5 \\
\hline Nashville & -0.76864 & 0 & 1 & 1 & 8 \\
\hline New Orleans & -0.01792 & 0.54 & 1 & 1 & 9 \\
\hline New York & -0.5083 & 0.53 & 12 & 13 & 65 \\
\hline Newark & -0.66384 & 0.68 & 1 & 1 & 8 \\
\hline Norfolk & -0.47747 & 0 & 1 & 2 & 13 \\
\hline N. Las Vegas & -0.21509 & 1.08 & 1 & 1 & 5 \\
\hline Oakland & -0.86761 & 0.77 & 3 & 3 & 9 \\
\hline Oklahoma City & 0.256023 & 1.54 & 4 & 4 & 38 \\
\hline Omaha & 0.075734 & 1.11 & 2 & 2 & 14 \\
\hline Orlando & -0.00713 & 1.69 & 5 & 5 & 16 \\
\hline Philadelphia & -0.52064 & 0.07 & 1 & 1 & 29 \\
\hline Phoenix & -0.0406 & 0.79 & 13 & 13 & 75 \\
\hline Pittsburgh & -0.48543 & 1.49 & 1 & 1 & 5 \\
\hline Plano & 0.371291 & 0 & 0 & 0 & 2 \\
\hline Portland & -0.59138 & 1.1 & 4 & 1 & 10 \\
\hline Raleigh & -0.28611 & 0 & 0 & 0 & 4 \\
\hline Reno & -0.03509 & 1.07 & 1 & 1 & 10 \\
\hline Riverside & -0.07249 & 0.43 & 0 & 0 & 7 \\
\hline Rochester & -0.60425 & 1.36 & 1 & 1 & 3 \\
\hline Sacramento & -0.3256 & 1.11 & 1 & 1 & 10 \\
\hline San Antonio & -0.01145 & 2.14 & 7 & 7 & 33 \\
\hline San Bernardino & -0.11585 & 1.24 & 0 & 0 & 9 \\
\hline San Diego & -0.35573 & 2.01 & 7 & 7 & 24 \\
\hline San Francisco & -0.99965 & 2.27 & 4 & 4 & 18 \\
\hline San Jose & -0.32111 & 1.1 & 2 & 2 & 16 \\
\hline Santa Ana & -0.19081 & 1.17 & 2 & 2 & 14 \\
\hline
\end{tabular}


Police Institutions and Police Abuse: Evidence from the US

\begin{tabular}{cccccc}
\hline Scottsdale & 0.059812 & 0.07 & 1 & 1 & 6 \\
Seattle & -0.86791 & 2.09 & 2 & 2 & 19 \\
Spokane & -0.16081 & 1.13 & 1 & 1 & 14 \\
St. Louis & -0.52105 & 0.81 & 3 & 3 & 31 \\
St. Paul & -0.57337 & 0.67 & 1 & 1 & 12 \\
St. Petersburg & -0.36202 & 2.05 & 1 & 0 & 10 \\
Stockton & -0.19927 & 0.84 & 4 & 3 & 17 \\
Tampa & -0.16116 & 1.76 & 3 & 3 & 7 \\
Toledo & -0.16977 & 0.51 & 1 & 0 & 5 \\
Tucson & -0.22628 & 0.99 & 1 & 1 & 20 \\
Tulsa & 0.073673 & 0.5 & 6 & 6 & 19 \\
Virginia Beach & 0.253696 & 0 & 1 & 1 & 3 \\
Washington & -0.92538 & 1.82 & 4 & 4 & 16 \\
Wichita & -0.02876 & 0.72 & 2 & 2 & 10 \\
Winston-Salem & -0.09854 & 0 & 1 & 1 & 3 \\
\hline
\end{tabular}




\section{Appendix I: Justifying Regression Method \& Alternate Methods}

\section{Negative Binomial Regression}

There are a range of different regressions that could be used to run these models. After consultation and careful consideration, I decided to use an OLS regression with regional fixed effects (results in Table 6).

Nonetheless, I was between the selected method and the negative binomial regression, primarily because negative binomial regressions are best suited for dependent variables which are "counts" - in this case, deaths of civilians. Table 5 presents the mean and standard deviation which are not the same, thus, making it inappropriate to use a Poisson distribution.

Employing a negative binomial regression seems suitable since it has been prescribed specifically for dependent variables that are counts. I have run the primary model being investigated in this thesis: the relationship between police abuse and police protections. As illustrated in the table above, the negative binomial regression is positive and significant. Thus, demonstrating a similar effect to the model run in the thesis. However, one criticism of employing a negative binomial regression is when it is applied to small sample sizes. This can lead to problems where it becomes very difficult to obtain a reliable estimate of "the overdispersion parameter." 314

\footnotetext{
314 "Negative binomial distribution: Use \& misuse - contagious distribution, overdispersion parameter, truncation, log series, log normal distribution" [Web Page]
} 


\begin{tabular}{|c|c|c|c|}
\hline & \multicolumn{3}{|c|}{ Dependent variable: } \\
\hline & & POLICE ABUS & \\
\hline & (1) & (2) & (3) \\
\hline POLICE PROTECTIONS & $\begin{array}{c}0.4808^{* * *} \\
(0.1024)\end{array}$ & $\begin{array}{c}0.4660^{* * *} \\
(0.1026)\end{array}$ & $\begin{array}{c}0.4689^{* * *} \\
(0.0992)\end{array}$ \\
\hline POPULATION & $\begin{array}{c}0.000001^{* * *} \\
(0.000000)\end{array}$ & $\begin{array}{c}0.000001^{* * *} \\
(0.000000)\end{array}$ & $\begin{array}{l}0.000001^{* *} \\
(0.000000)\end{array}$ \\
\hline VIOLENT CRIME RATE & $\begin{array}{c}0.0670^{* * *} \\
(0.0208)\end{array}$ & $\begin{array}{l}0.0577^{*} \\
(0.0302)\end{array}$ & $\begin{array}{c}0.0277 \\
(0.0245)\end{array}$ \\
\hline SIZE OF DEPARTMENT & $\begin{array}{l}-0.0001 \\
(0.0001)\end{array}$ & $\begin{array}{l}-0.0001 \\
(0.0001)\end{array}$ & $\begin{array}{l}-0.0001 \\
(0.0001)\end{array}$ \\
\hline BLACK_MT & & $\begin{array}{c}0.0048 \\
(0.0080)\end{array}$ & \\
\hline HISPANIC_MT & & $\begin{array}{l}0.0090^{*} \\
(0.0052)\end{array}$ & \\
\hline BLACK SPATIAL & & & $\begin{array}{l}0.0152^{*} \\
(0.0084)\end{array}$ \\
\hline HISPANIC SPATIAL & & & $\begin{array}{c}0.0103 \\
(0.0094)\end{array}$ \\
\hline NORTH & $\begin{array}{c}0.3486 \\
(0.5584)\end{array}$ & $\begin{array}{c}0.1170 \\
(0.6082)\end{array}$ & $\begin{array}{c}0.2203 \\
(0.5486)\end{array}$ \\
\hline SOUTH & $\begin{array}{c}0.6572 \\
(0.5484)\end{array}$ & $\begin{array}{c}0.3821 \\
(0.6237)\end{array}$ & $\begin{array}{c}0.5108 \\
(0.5442)\end{array}$ \\
\hline NORTHWEST & $\begin{array}{c}0.1890 \\
(0.3799)\end{array}$ & $\begin{array}{c}0.0098 \\
(0.4061)\end{array}$ & $\begin{array}{c}0.3530 \\
(0.3760)\end{array}$ \\
\hline SOUTHWEST & $\begin{array}{c}0.6753 \\
(0.5355)\end{array}$ & $\begin{array}{c}0.2234 \\
(0.6030)\end{array}$ & $\begin{array}{c}0.6400 \\
(0.5157)\end{array}$ \\
\hline Constant & $\begin{array}{l}-0.8943 \\
(0.5771)\end{array}$ & $\begin{array}{l}-0.8149 \\
(0.5980)\end{array}$ & $\begin{array}{c}-1.6095^{* * *} \\
(0.6247)\end{array}$ \\
\hline Observations & 100 & 100 & 100 \\
\hline Log Likelihood & -193.0459 & -191.6531 & -189.2928 \\
\hline theta & $5.2919^{* * *}(1.8836$ & $5.7666^{* * *}(2.148$ & $7.4298^{* *}(3.2716)$ \\
\hline Akaike Inf. Crit. & 404.0918 & 405.3061 & 400.5855 \\
\hline
\end{tabular}

Moreover, there is nothing, on a technical aspect, with using an OLS model. The simplicity allows the model to be better informed.

\section{R-Studio}

I have used R-studio to run all of the regressions which were done in several multiple scripts employing a range of packages. Some packages include: "LFE” (Linear Fixed 
Effects), "Stargazer" (Formatting), "MASS" (Generalized Linear Models), “GGPLOT2"

(Graphing), etc.

This includes tables, graphs, principal components analysis, regressions and almost all processes requiring statistical analysis. Excel was used at points to sift through data and look for missing observations for purposes of ease of access.

Inclusion of the R-Scripts would not be reasonable to include because of length.

Nonetheless, all scripts are stored and can be produced upon request. Below are a few examples of R-Scripts written:
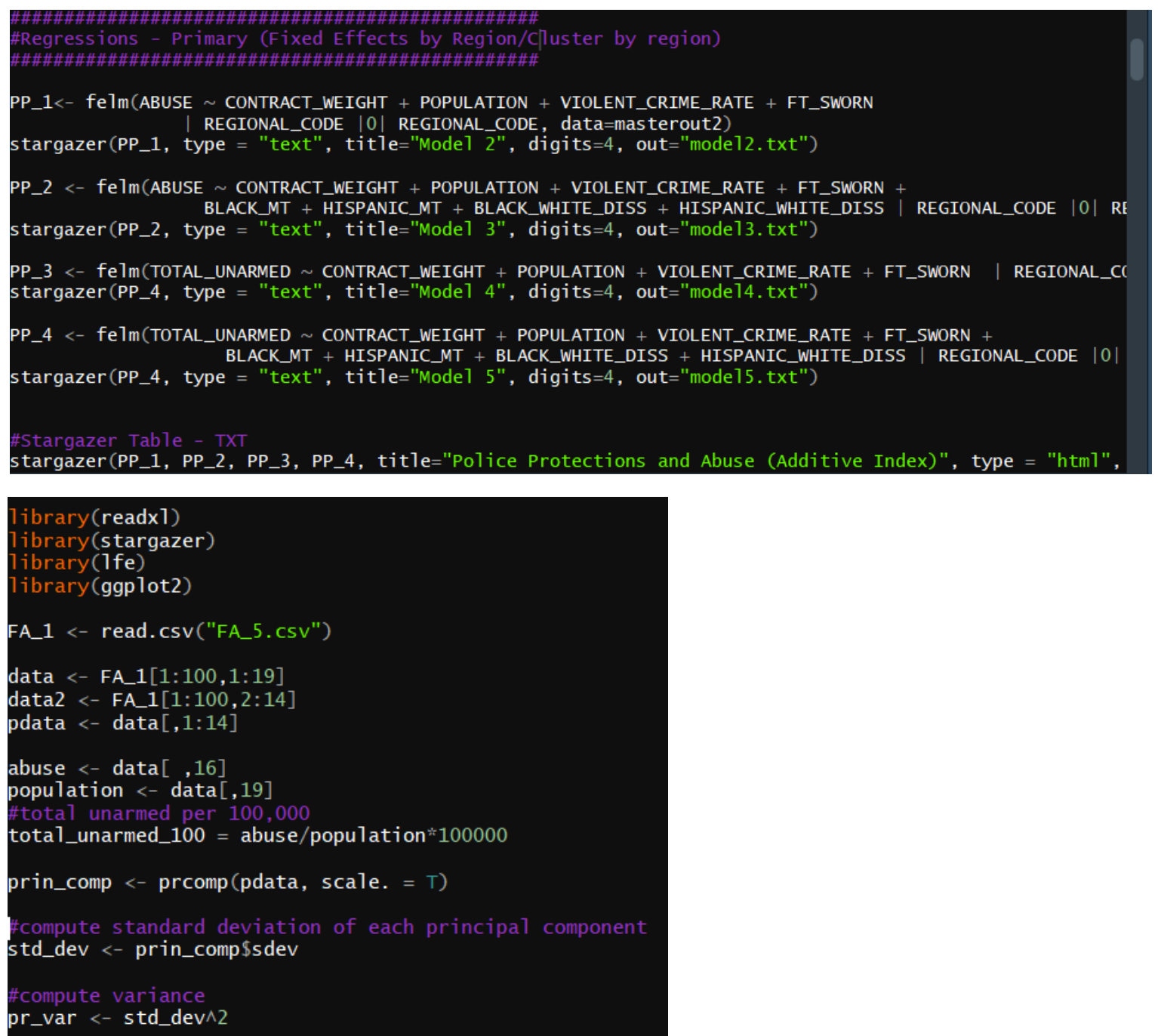


\section{Appendix J: Alternative Institutional Variables}

The basic findings in Table 6 are sufficient and have explored the central hypothesis this study hoped to confirm - successfully highlighting the impact of police unions through quantitative analysis. This is an important step toward understanding the effects of union contract protections on a larger scale and, in turn, better understanding the problems in America's policing apparatus.

One institutional factor not captured in the models above is the impact of use of force policies and how they may explain police abuse variation between cities. Cities with more refined use of force policies have been found to be correlated with fewer police killings. ${ }^{315}$ While I expect police protections to be significant, I cannot predict whether they will be as significant as the use of force policies which have already been established to be relevant to police killings. Use of force policies can also be viewed as a proxy for the level of rigorous training an officer receives surrounding use of force. ${ }^{316}$

The use of force policy index is an originally constructed variable by Campaign Zero which uses the same unit of analyses and temporal scope as this study. ${ }^{317}$ Therefore, this variable is applicable to the model tested in this study. The variable takes into account eight provisions which they identify to be relevant after consulting legal experts, academics and police reformers. ${ }^{318}$ The inclusion of the following provisions was argued to create fairer use-of-force policies:

\footnotetext{
315 McKesson, Sinyangwe, and Packnett, 2016.

316 Gupta, 2015. Level of training has been argued to be a crucial variable in explaining good and bad policing in the past. 317 McKesson, Sinyangwe, and Packnett, 2016. "Among the 100 police departments requested, 94 departments submitted use of force policies. 3 of these policies were heavily redacted and, as such, were excluded from the analysis."

318 McKesson, Sinyangwe, and Packnett, 2016.
} 
“1. Failing to make life preservation the primary principle shaping police decisions about using force

2. Failing to require officers to de-escalate situations, where possible, by communicating with subjects, maintaining distance, and otherwise eliminating the need to use force

3. Allowing officers to choke or strangle civilians, in many cases where less lethal force could be used instead, resulting in the unnecessary death or serious injury of civilians

4. Failing to require officers to intervene and stop excessive force used by other officers and report these incidents immediately to a supervisor

5. Failing to develop a Force Continuum that limits the types of force and/or weapons that can be used to respond to specific types of resistance.

6. Failing to require officers to exhaust all other reasonable means before resorting to deadly force.

7. Failing to require officers to give a verbal warning, when possible, before shooting at a civilian.

8. Failing to require officers to report each time they use force or threaten to use force against civilians." 319

The authors than created an additive index (binary) of whether the specific type of provision exists or not in the use-of-force policy. He then proceeded to create a composite score for each city where a higher score represents a refined and rigorous use-of-force policy and a lower score represents a weaker policy.

319 McKesson, Sinyangwe, and Packnett, 2016. 
The table above creates a more rigorous model which tests the saliency of the effects of both the police protections index and the use-of-force policy index on police abuse. Sinyangwe employs police killings as the dependent variable in his study which is a distinction worth noting since the primary dependent variable in this study is police abuse. Thus, if police protections have a significant impact on abuse even when conditioned upon use-of-force policies than this will only further build support for the role of police protections in helping insulate abuse. According to Sinyangwe' study, I expect there to be a significant negative correlation between use-of-force policy and police abuse. The is because the index works on an additive scale where a higher score represents use-of-force policies that are more rigorous and refined.

Column 1 in the table below finds that the type of use-of-force policy in place is significant with police abuse. It has a negative correlation (-.10) as predicted, whereas, police protections have a positive effect (.36). While both are statistically significant, protections appear to be a stronger determinant of police abuse even when considering the type of use-of-force policy which a department implements.

Column 2 focuses on the MT hypothesis. Only the Black MT variable is statistically significant (.04). Interestingly, use of force is no longer significant. Similar to the previous models, police protections have a slightly larger effect when including race-related variables moving from .53 to .55 .

Furthermore, the Black Spatial hypothesis appears to be relevant and significant as shown in Column 3. Police protections doesn't seem to experience too much variation between the MT and Place variables (.55 to .54) but use of force has appears to be significant and have a strongest effect when controlling for Spatial variables (-.12). Finally, when considering all the 
variables of interest, police protections (.55) and both the Black MT and Black Spatial variables continue to be significant. Both the Hispanic MT and Spatial variable are insignificant and have no effect. The use of force index is insignificant once again.

One concern with overstating the impact of police protections over use of force policy is that there is a possibility that use-of-force policies are influenced and shaped by unions. Thus, it is plausible to argue that use force policies are another way unions can insulate existing policing practices. Nevertheless, this area is beyond the scope of this study but requires further exploration. 
Appendix J Table Regressions | Alternative Institutional Regressions

POLICE PROTECTIONS, USE OF FORCE \& POLICE ABUSE

\begin{tabular}{|c|c|c|c|c|}
\hline & \multicolumn{4}{|c|}{ Dependent variable: } \\
\hline & \multicolumn{4}{|c|}{ POLICE ABUSE } \\
\hline & (1) & (2) & (3) & (4) \\
\hline POLICE PROTECTIONS & $\begin{array}{l}0.5275^{* *} \\
(0.2327)\end{array}$ & $\begin{array}{l}0.5516^{* *} \\
(0.2291)\end{array}$ & $\begin{array}{l}0.5369^{* *} \\
(0.2252)\end{array}$ & $\begin{array}{l}0.5460^{* *} \\
(0.2353)\end{array}$ \\
\hline USE OF FORCE & $\begin{array}{c}-0.1025^{* *} \\
(0.0472)\end{array}$ & $\begin{array}{l}-0.0793 \\
(0.0609)\end{array}$ & $\begin{array}{l}-0.1216^{*} \\
(0.0721)\end{array}$ & $\begin{array}{l}-0.0962 \\
(0.0862)\end{array}$ \\
\hline POPULATION & $\begin{array}{c}0.000003 \\
(0.000003)\end{array}$ & $\begin{array}{c}0.000004 \\
(0.000003)\end{array}$ & $\begin{array}{c}0.000002 \\
(0.000003)\end{array}$ & $\begin{array}{c}0.000003 \\
(0.000003)\end{array}$ \\
\hline VIOLENT CRIME RATE & $\begin{array}{c}0.1255 \\
(0.0780)\end{array}$ & $\begin{array}{c}0.0376 \\
(0.0695)\end{array}$ & $\begin{array}{l}-0.0094 \\
(0.1211)\end{array}$ & $\begin{array}{l}-0.0592 \\
(0.1267)\end{array}$ \\
\hline SIZE OF DEPARTMENT & $\begin{array}{l}-0.0003 \\
(0.0007)\end{array}$ & $\begin{array}{l}-0.0004 \\
(0.0006)\end{array}$ & $\begin{array}{l}-0.0001 \\
(0.0006)\end{array}$ & $\begin{array}{l}-0.0002 \\
(0.0006)\end{array}$ \\
\hline BLACK_MT & & $\begin{array}{c}0.0380^{* * *} \\
(0.0108)\end{array}$ & & $\begin{array}{l}0.0272^{* *} \\
(0.0113)\end{array}$ \\
\hline HISPANIC_MT & & $\begin{array}{c}0.0300 \\
(0.0203)\end{array}$ & & $\begin{array}{c}0.0293 \\
(0.0193)\end{array}$ \\
\hline BLACK SPATIAL & & & $\begin{array}{c}0.0515^{* * *} \\
(0.0172)\end{array}$ & $\begin{array}{l}0.0495^{* *} \\
(0.0205)\end{array}$ \\
\hline HISPANIC SPATIAL & & & $\begin{array}{c}0.0206 \\
(0.0218)\end{array}$ & $\begin{array}{c}0.0161 \\
(0.0211)\end{array}$ \\
\hline Observations & 100 & 100 & 100 & 100 \\
\hline $\mathrm{R}^{2}$ & 0.5119 & 0.5300 & 0.5358 & 0.5497 \\
\hline Adjusted $\mathrm{R}^{2}$ & 0.4690 & 0.4772 & 0.4837 & 0.4876 \\
\hline Residual Std. Error & $2.9695(\mathrm{df}=91)$ & $2.9466(\mathrm{df}=89$ & $2.9283(\mathrm{df}=89)$ & $2.9169(\mathrm{df}=87)$ \\
\hline
\end{tabular}

This model, as well as the first few models discussed in the analysis, have provided strong and consistent evidence on the positive relationship between police abuse and an important union mechanism, police protections. The index and method employed can be a framework for future studies to understand the relationship between police protections and other relevant variables which will be made available in the near future such as excessive use of force. 
This model finds that provisions which have been argued to reduce deterrence and create problems for accountability exist in cities with greater levels of police abuse. This originally constructed index is the first attempt in police unionism literature to quantitatively test the impact of union contracts on a large number of observations. 


\section{Appendix K: Interviews}

The interviews conducted for this study were approved by the Central University Research

Ethics Committee (CUREC).

\section{Interviews}

\begin{tabular}{|c|c|c|c|}
\hline Name & Date & Location & Occupation/Rank \\
\hline $\begin{array}{l}\text { Chicago Police } \\
\text { Department (01) }\end{array}$ & $8 / 16 / 2017$ & Chicago, IL & $\begin{array}{l}\text { Police Officer/FOP } \\
\text { Union Member }\end{array}$ \\
\hline $\begin{array}{l}\text { Chicago Police } \\
\text { Department (02) }\end{array}$ & $8 / 16 / 2017$ & Chicago, IL & Police Officer \\
\hline $\begin{array}{l}\text { Chicago Police } \\
\text { Department (03) }\end{array}$ & $8 / 17 / 2017$ & Chicago, IL & $\begin{array}{l}\text { Detective/FOP } \\
\text { Member }\end{array}$ \\
\hline $\begin{array}{l}\text { Chicago Police } \\
\text { Department (04) }\end{array}$ & $8 / 17 / 2017$ & Chicago, IL & $\begin{array}{l}\text { Police Officer/FOP } \\
\text { Union Member }\end{array}$ \\
\hline $\begin{array}{l}\text { Chicago Police } \\
\text { Department (05) }\end{array}$ & $8 / 17 / 2017$ & Chicago, IL & $\begin{array}{l}\text { Police Officer/FOP } \\
\text { Union Member }\end{array}$ \\
\hline $\begin{array}{l}\text { Dallas Police } \\
\text { Department (01) }\end{array}$ & $1 / 18 / 2018$ & $\begin{array}{l}\text { Dallas, TX } \\
\text { (remote) }\end{array}$ & $\begin{array}{l}\text { Sergeant/DPA } \\
\text { Member }\end{array}$ \\
\hline $\begin{array}{l}\text { Dallas Police } \\
\text { Department (02) }\end{array}$ & $2 / 16 / 2018$ & $\begin{array}{l}\text { Dallas, TX } \\
\text { (remote) }\end{array}$ & Major/DPA Member \\
\hline $\begin{array}{l}\text { Dallas Police } \\
\text { Department (03) }\end{array}$ & $3 / 1 / 2018$ & $\begin{array}{l}\text { Dallas, TX } \\
\text { (remote) }\end{array}$ & $\begin{array}{l}\text { Detective/DPA } \\
\text { Member and Staff }\end{array}$ \\
\hline $\begin{array}{l}\text { Dallas Police } \\
\text { Department (04) }\end{array}$ & $3 / 2 / 2018$ & $\begin{array}{l}\text { Dallas, TX } \\
\text { (remote) }\end{array}$ & $\begin{array}{l}\text { Sergeant/DPA } \\
\text { Member }\end{array}$ \\
\hline $\begin{array}{l}\text { Dallas Police } \\
\text { Department (05) }\end{array}$ & $3 / 8 / 2018$ & $\begin{array}{l}\text { Dallas, TX } \\
\text { (remote) }\end{array}$ & $\begin{array}{l}\text { Corporal/DPA } \\
\text { Member/BPAD } \\
\text { Member }\end{array}$ \\
\hline Jonathan Smith & $9 / 7 / 17$ & Washington, DC & $\begin{array}{l}\text { Former Chief of } \\
\text { Special Litigation Unit } \\
\text { - Civil Rights Division, } \\
\text { US DOJ }\end{array}$ \\
\hline City of Dallas & $12 / 8 / 2017$ & $\begin{array}{l}\text { Dallas, TX } \\
\text { (remote) }\end{array}$ & $\begin{array}{l}\text { Elected/Appointed } \\
\text { City Representative }\end{array}$ \\
\hline City of Dallas & $01 / 7 / 2018$ & $\begin{array}{l}\text { Dallas, TX } \\
\text { (remote) }\end{array}$ & $\begin{array}{l}\text { Elected/Appointed } \\
\text { City Representative }\end{array}$ \\
\hline City of Chicago & $3 / 16 / 2018$ & $\begin{array}{l}\text { Chicago, IL } \\
\text { (remote) }\end{array}$ & $\begin{array}{l}\text { Elected/Appointed } \\
\text { City Representative }\end{array}$ \\
\hline City of Chicago & $2 / 2 / 2018$ & $\begin{array}{l}\text { Chicago, IL } \\
\text { (remote) }\end{array}$ & $\begin{array}{l}\text { Elected/Appointed } \\
\text { City Representative }\end{array}$ \\
\hline
\end{tabular}


All interviewees (except the federal interview) requested anonymity in exchange for participating for the interview because of fears of retaliation and other problems that could potentially emerge. Interview transcripts are not included because of length. Recordings can be produced upon request in accordance with CUREC regulations. 